Universidade de Brasília

Faculdade de Comunicação Social

Programa de Pós-graduação em Comunicação Social

\author{
Lorena Silva Bicalho Rodrigues
}

\title{
MEMÓRIAS E EXPERIÊNCIAS DE MÃES uma análise semiótica
}


Universidade de Brasília

Faculdade de Comunicação Social

Programa de Pós-graduação em Comunicação Social

\author{
Lorena Silva Bicalho Rodrigues
}

\title{
MEMÓRIAS E EXPERIÊNCIAS DE MÃES uma análise semiótica
}

Dissertação apresentada ao Programa de PósGraduação em Comunicação da Universidade de Brasília/UnB como parte dos requisitos para a obtenção do título de Mestre

Brasília - DF 
Universidade de Brasília

Faculdade de Comunicação Social

Programa de Pós-graduação em Comunicação Social

Dissertação de mestrado, intitulada Memórias de mães: uma análise semiótica, de autoria da pesquisadora Lorena Silva Bicalho Rodrigues, apresentada pelo Programa de Pós-graduação em Comunicação Social, na área de Teorias e Tecnologias da Comunicação - Semiótica, da Faculdade de Comunicação da Universidade de Brasília, aprovada pela banca examinadora.

Brasília, 05 de dezembro de 2016.

Dr. Pedro Russi Duarte

Universidade de Brasília - Presidente

Dra. Elisa Martinez

Universidade de Brasília - Membro Externo à Faculdade de Comunicação

Dra. Fabíola Calazans

Universidade de Brasília - Membro Interno à Faculdade de Comunicação

Dra. Cláudia Busato

Centro Universitário de Brasília - UniCEUB - Membro Externo - Suplente 
À minha mãe, Lúcia, pelos caminhos que construimos juntas. 


\section{Agradecimentos}

À minha avó, Maria Rute, pelas narrativas que me conta e por ser referência para mim do que é ser mãe e avó de uma família inteira.

Ao meu pai, Alfredo, que sempre me acompanha.

Às minhas duas irmãs, Marina e Nicole, que são parte de mim.

À Vânia, pela paciência em me ouvir e pela preocupação.

Ao professor Pedro Russi, que me acompa desde a graduação - sem palavras para expressar o que compartilhou comigo em diálogos para a construção do conhecimento; principalmente por compartilhar experiências comigo.

Aos amigos e colegas de mestrado, que me acolheram na Universidade com muito respeito e amizade, pelo compromisso de cada um com o conhecimento, foi o que me fez acreditar em diálogos possíveis; em especial à professora Suzane Oliveira, pelas discussões e textos em sala de aula, que me fizeram repensar muitas questões, e pela preocupação em melhorar o mundo em que vivemos.

Ao pessoal da Diretoria de Esporte, Arte e Cultura da Universidade de Brasília (DEA-UnB), que compreendeu minha dificuldade às vezes de conciliar DEA, mestrado e capoeira.

Aos camaradas, por tudo o que envolve capoeira, especialmente aos meus professores e à mestra Elma, pelos ensinamentos.

À Clara, pelos comentários que teceu sobre este texto, pelo cuidado.

Aos amigos, que compreenderam minhas ausências e presenças neste período de mestrado; em especial à querida Ana Rosa, pela atenção e companhia diárias.

Às mães entrevistadas, que me confiaram um pouco de suas histórias, pensamentos e emoções.

Às dissertações que trazem esta seção, sempre gosto de lê-la. 


\section{LISTA DE IMAGENS}

Figura 1 - Giampietrino, O menino e São João Batista criança em adoração, 1500-1520, Itália........ 40

Figura 2 - Ambrogio Lorenzetti, Virgen con ángeles y saints, 1335, Itália. .45

Figura 3 - Gustav Klimt, Mother and Child, 1905, Áustria. .48

Figura 4 - Gustav Klimt, Hope II, 1907-1908, Áustria. .49

Figuras 5, 6, 7 e 8 - Pablo Picasso, Las meninas, 1957, Espanha. .98 


\section{LISTA DE ENTREVISTADAS}

1- Marinalva, 29 anos, é branca, classe média, professora, capoeirista, tem uma filha de 3 anos e é casada com o pai da menina. Os três sempre moraram em Brasília.

2- Fátima, funcionária pública, 36 anos, branca, tem um filho de 6 anos e sempre morou em Brasília. Ela conta que já tinha vontade de ter filhos e que morou com o pai depois do nascimento. Hoje estão separados.

3- Bianca, 20 anos, negra, estudante universitária, brasiliense, conta que a mãe sofreu muito para conseguir criar os filhos por ter recursos financeiros muitas vezes escassos. Essa experiência a faz não ter vontade de ter filhos.

4- Fabíola, 28 anos, é capoeirista, funcionária pública, branca, tem uma filha de quatro meses. Saiu de Brasília no início de 2015 para Morar em São Luís. Está casada com o pai da filha, maranhense, negro. Ela conta que já planejava casar-se e ter filhos há algum tempo.

5- Vânia, 57 anos, negra, funcionária pública, mineira, três filhas, divorciada. Mora em Brasília com a filha mais nova.

6- Roberta, 22 anos, branca, artesã, brasiliense. Tem uma filha de 3 anos, morou com o pai da menina, mas agora mora com a filha e a mãe, doméstica, em Brasília.

7- Cordolina, 28 anos, mestiça, atendente em loja, brasiliense. Ela tem um filho de 6 anos e sempre morou em Brasília. É casada com o pai da criança.

8- Rute, 57 anos, auditora fiscal, branca, mineira, morou em Palmas (TO) por 4 anos e mora em Brasília há 18 anos, vieram para cá para que o filho, hoje com 36 anos, cursasse ensino superior na Universidade de Brasília. Nunca morou com o pai de seu filho. Hoje é casada. 
9- Maria, 54 anos, negra, doméstica, tem dois filhos de 28 e 26 anos, e uma filha de 10. Piauiense, mora em Brasília com o marido, também piauiense, negro. Teve os três filhos com ele. Já trabalhou como costureira em fábrica, como cozinheira em restaurante. E trabalha há 18 anos em uma casa de família como doméstica.

10- Camila, 54 anos, negra, maranhense, funcionária pública, artista. Engravidou cinco vezes. Teve um primeiro aborto forçado, outro, natural, e uma filha que morreu após 16 dias do nascimento. O filho mais velho, Pedro, hoje com 28 anos, é especial. Também tem outro filho, de 22 anos, os dois com o ex-marido em Brasília. Ainda reside na cidade.

11- Clara, 30 anos, branca, professora, tem um filho de três anos e mora em Brasília. Está casada com o pai do menino, que mora em Belo Horizonte por conta de um concurso que prestou para lá.

12- Carmem, 36 anos, branca, maranhense, mora em Brasília desde criança. Funcionária pública. Namora e não pensa em ter filhos.

13- Florbela, 48 anos, negra, funcionária pública, tem um filho de 30 anos e está casada com o pai. Mora em Brasília há 30 anos.

14- Camomila, 26 anos, branca, artesã, não tem filhos, mas pensa em ter. Nasceu e sempre viveu em Brasília.

15- Laura, 25 anos, branca, estudante universitária, nasceu e vive em Brasília. Pensa em ter filhos.

16- Cássia, 18 anos, branca, estudante universitária, brasiliense e mora na cidade. Pensa em adotar uma criança.

17- Vanessa, 57 anos, negra, funcionária pública, tem duas filhas: de 20 e 27 anos. Nasceu em São Paulo e veio para Brasília com 24 anos. Está separada do pai das filhas. 
18- Berenice, 87 anos, branca, aposentada, tem quatro filhos, mineira, mora em Brasília desde os 38 anos. O pai dos filhos falaceu. Atualmente mora sozinha.

19- Vitória, 31 anos, branca, funcionária pública. Nasceu e vive em Brasília. Tem um filho de 3 anos. Não mora com o pai da criança.

20- Isadora, 30 anos, tem duas filhas, de 1 e 3 anos, branca, casada com o pai das meninas. Nasceu e mora em Brasília. 
Toque de Benguela

"Mãe África engravidou Nhá Angola

Partiu de Luanda e de Benguela

Chegou e pariu a capoeira

No chão do Brasil verde e amarela

É de Angola!

Camará que me veio esta cantiga

De Luanda!

É um jogo, é uma dança, é uma briga

De Benguela!

No quilombo da Serra da Barriga

De Aruanda!

Capoeira chegou com a caravela

Mãe África engravidou Nhá Angola

Partiu de Luanda e de Benguela

Chegou e pariu a capoeira

No chão do Brasil verde e amarela

É de Angola!

O meu corpo é de pinho de riga

De Luanda!

De madeira de lei é minha figa

De Benguela!

Sou aluno da capoeira antiga

De Aruanda!

Ganga Zumba é que é meu sentinela

Mãe África engravidou Nhá Angola

Partiu de Luanda e de Benguela

Chegou e pariu a capoeira

No chão do Brasil verde e amarela

É de Angola!

Mangagá nunca foi nem é de intriga

De Luanda!

E esse sangue africano é minha liga

De Benguela!

Capoeira que é bom ninguém instiga

De Aruanda!

Se instigar vai provar o veneno dela

Mãe África engravidou Nhá Angola

Partiu de Luanda e de Benguela

Chegou e pariu a capoeira

No chão do Brasil verde e amarela

É de Angola!

Camará que me veio esta cantiga

Camará!"

(Paulo César Pinheiro) 


\section{RESUMO}

Esta dissertação trata dos processos de formação de sentido do/no self das mulheres a partir do momento em que se tornam mães. Nesse sentido, busca-se entender os movimentos da memória para um reposicionamento das mulheres por meio do que compreendem sobre o conceito de mãe. A questão-problema que se coloca é a seguinte: como o self mãe cria forma? Na procura por respostas e caminhos possíveis, são entrevistadas 15 mães e 5 mulheres sem filhos a fim de se entender os processos de inquirição que as permitem viverem na nova situação, após o nascimento do(a) filho(a). Esta investigação traz como metodologia de análise o Pragmaticismo, desenvolvido para tornar os conceitos claros. Nas falas das entrevistadas e, também, em conversas do dia-a-dia, procura-se por hábitos comuns referentes à concepção do que é ser mãe no Brasil. Compreende-se, a partir de Peirce (1878), que os significados das coisas no mundo encerram-se nos hábitos que elas produzem.

Palavras-chave: semiótica, self, mãe, pragmaticismo, hábitos. 


\begin{abstract}
This dissertation deals with the meaning's formations in the women's self from the moment they become mothers. In this sense, it is sought to understand the memory's movements for a repositioning of women from what they understand about the concept of mother. The problem question that arises is this: how does the mother self creat form? In the search for possible answers and paths, 15 mothers and 5 childless women are interviewed in order to understand the processes of inquiry that allow them to live in the new situation, after the child's birth. This research brings the Pragmaticism as a methodology of analysis, which was developed to clear concepts. In the interviewees' speeches, and also in everyday conversations, one looks for common habits regarding the conception of what it is to be a mother in Brazil. It is understood, from Peirce (1878), that the meanings of things in the world are enclosed in the habits they produce.
\end{abstract}

Keywords: semiotics, self, mother, pragmaticism, habits. 


\section{SUMÁRIO}

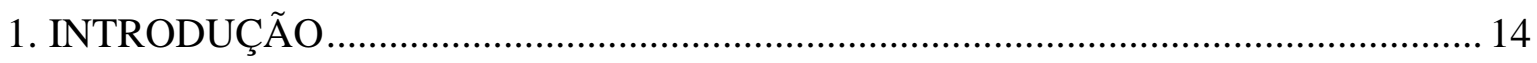

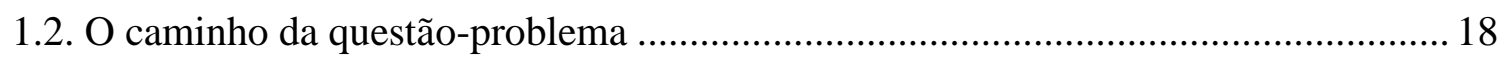

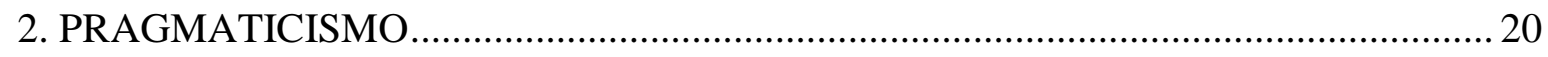

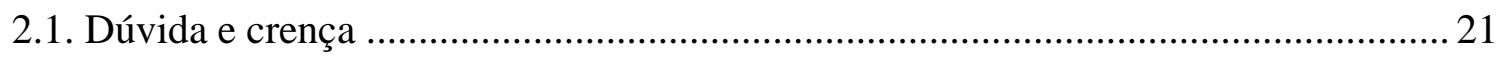

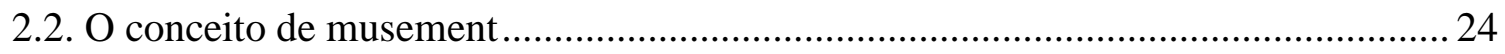

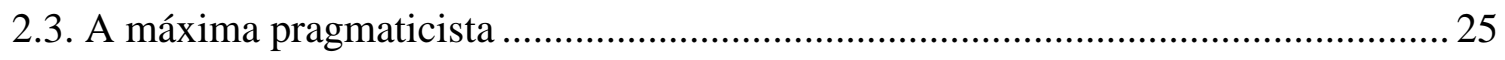

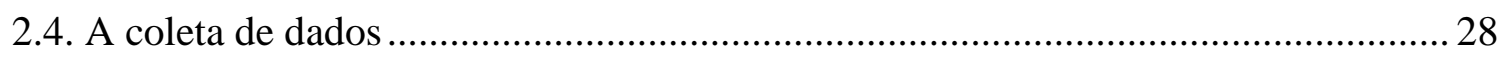

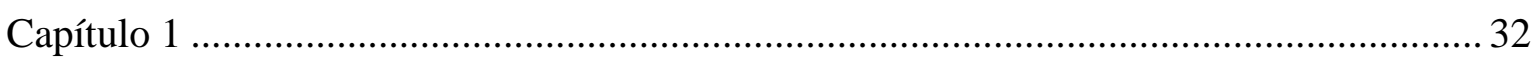

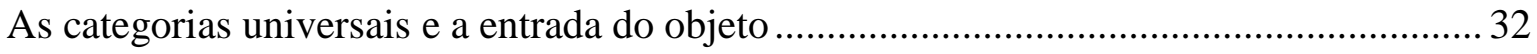

3.1. As três categorias universais: avanços para a compreensão da semiose .................. 32

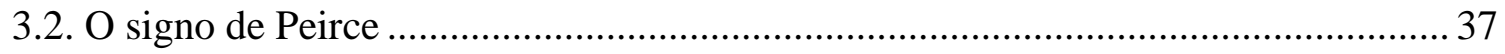

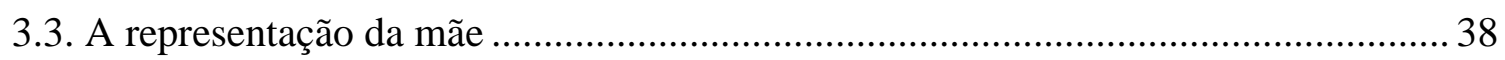

3.3.1. A virgem Maria como representação de pureza................................................ 38

3.3.1.2. Completude e incompletude e o caso das amas-de-leite ............................... 46

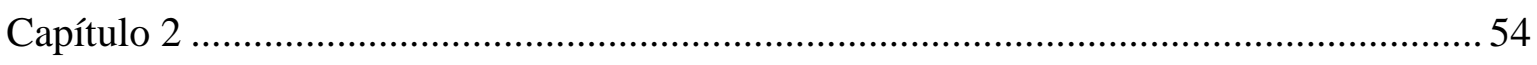

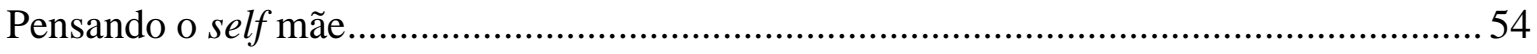

4.1. Nomeação e ação em trabalho e jogo ....................................................................... 54

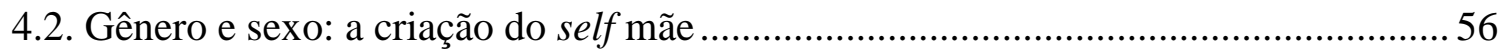

4.2.1. As formações de sentido no self na constituição de corpos sexuados.................58

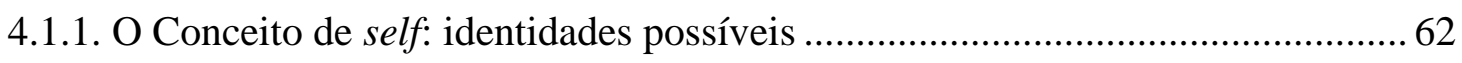

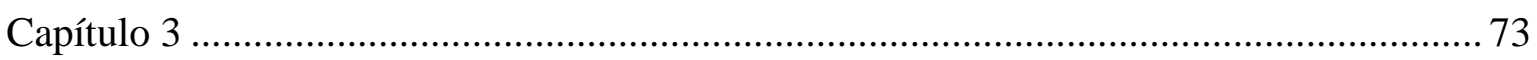

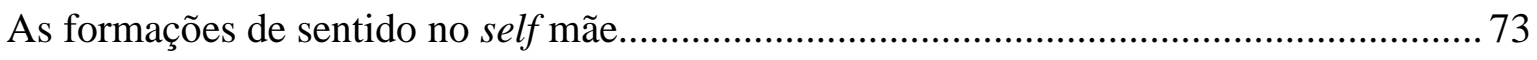

5.1. Personalidade como coordenação de ideias ............................................................ 74

5.1.1. O self e as possibilidades da primeiridade ........................................................ 79

5.1.2 Compartilhamento entre selves em processos de nomeação ............................... 85

5.2. A passagem do tempo e as transformações na memória......................................... 89

5.2.1. As formações de sentido na memória .......................................................... 92

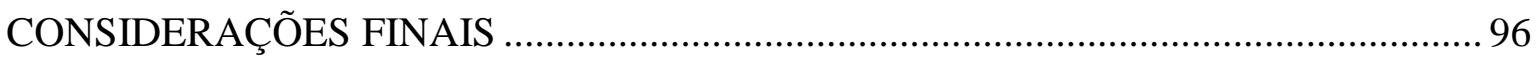

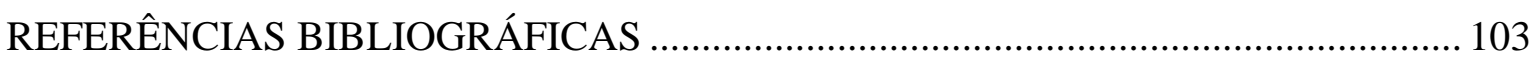




\section{INTRODUÇÃO}

Se você, camará, entrar, eu entro, Vim aqui pra jogar jogo de dentro. Pode vir, pode entrar, que eu me concentro, Vim aqui pra jogar jogo de dentro.

(Jogo de dentro, Paulo César Pinheiro).

"Toque de benguela" não é sobre o nascimento de um ser humano, mas sobre o nascimento da capoeira. A música fala da mãe África que engravidou. A princípio pode parecer meio estranho trazer essa música para falar da maternidade, mas ela vem como referência explícita ao que vem a seguir.

Depois de iniciar minha trajetória na capoeira angola, toda tarefa que traz certa dificuldade ou exige dedicação e força faz-me remeter a ela. E depois de ler o relato do mestre Cobra Mansa ${ }^{1}$, que será mencionado no título Pragmaticismo desta dissertação, fiquei instigada a citar um pouco de referências de corridos, vocabulário e ensinamentos que essa expressão cultural tem me proporcionado.

Trago as cantidas em cada capítulo em acordo com o que acho que tem a ver com o tema abordado na referida parte. A ideia é criar neste texto um pouco da sensação do jogo de angola: dividir a experiência do diálogo, bem como sentir o desafio premente e as emoções das ladainhas e corridos - que são as melodias tocadas na roda de capoeira. O diálogo se dá, neste texto, comigo mesma, na busca epistemológica que faço.

Primeiro gostaria de falar da dúvida, que foi o ponto inicial e o desenrolar desta dissertação. Ela provoca um estado de luta para que se atinja a crença. A esse processo, Peirce chama inquirição (2015, p. 8). A irritação é o único motivo imediato para a luta por atingir a crença; e essa é tal que possa guiar nossas ações. Se as ações resultantes da crença não nos guiam em acordo com nossos desejos, ao refletirmos tenderemos a rejeitá-la, mas para isso

\footnotetext{
${ }^{1}$ Cinézio Feliciano Peçanha é um mestre de Capoeira do gênero Angola, conhecido como Mestre Cobra Mansa e como Cobrinha. Nasceu em 1960, em Duque de Caxias, Rio de Janeiro e é um dos fundadores da Fundação Internacional de Capoeira de Angola (FICA), com sedes em diversos países da Europa, Américas e Ásia. Mestre Cobra Mansa começou sua jornada na capoeira em Duque de Caxias, em 1973, e é bem conhecido na capoeira mundial. Os nomes de roda Cobra Mansa e Cobrinha foram adotados por conta do estilo de luta e jogo dele. A habilidade para introduzir inovações e movimentos acrobáticos o transformou no mais influente Angoleiro (praticante de Capoeira de Angola) da sua geração.
} 
criaremos uma dúvida em seu lugar. Nesse caso, a luta reinicia, e só termina com o estabelecimento de uma opinião.

Com vistas então a estabelecer opinião, retiramos inferências que nos guiem pelo percurso da inquirição. Inferências que nos mostrem possibilidades de formular uma crença. E "aquilo que nos determina, a partir de premissas dadas, a retirar uma inferência ao invés de outra, é algum hábito da mente, quer seja constitucional ou adquirido”. (PEIRCE, 2015, p.5).

Esta dissertação teve início com uma dúvida e a partir dela outras surgiram, que impulsionaram ainda outras. Tomando o cuidado epistemológico necessário, meu caminho de pensamento é permeado por dúvidas que se apresentam à medida que prossigo. Finalmente cheguei à questão-problema: “Como o self ${ }^{2}$ mãe cria forma?”. Nesse processo, é possível aventar possibilidades, desenhar e redesenhar caminhos interpretativos e hipotéticos. Ao avançar na procura por respostas, as dificuldades surgem e agitam ainda mais inquietações: a investigação tem o prazer em sim mesma.

Gostaria de me remeter aqui a um conto de Cortázar (1982) - que está no capítulo "Perda e recuperação do cabelo" do livro Histórias de cronópios e de famas - em que a procura por um inútil fio de cabelo é instigante por permitir que a personagem arquitete as medidas para encontrá-lo. Retomando um dos trechos do livro, o narrador diz que, para lutar contra a tendência à consecução de fins úteis, o primo mais velho defende a prática de arrancar um bom fio de cabelo da cabeça, dar-lhe um nó no meio e deixá-lo cair suavemente pelo buraco da pia. Se ele ficar preso no ralo, bastará abrir um pouco a torneira para que se perca de vista. Em seguida, descreve as medidas para encontrá-lo:

Sem perda de um instante, deve-se iniciar a tarefa de recuperação do cabelo. A primeira operação se resume em desmontar o sifão da pia para ver se o cabelo ficou agarrado em alguma das sinuosidades do cano. Se não for encontrado, deve-se abrir o pedaço de cano que vai do sifão ao encanamento do esgoto principal. É certo que nessa parte aparecerão muitos cabelos e será preciso contar com a ajuda do resto da família para examiná-los um por um à procura do que tem o nó. Se não aparecer, colocar-se-á o interessante problema de quebrar o encanamento até o andar de baixo, mas isso significa um esforço maior, pois durante oito ou dez anos será necessário trabalhar em algum ministério ou numa casa de comércio para juntar o dinheiro que permita comprar os quatro apartamentos situados embaixo do de meu primo mais velho. [...] (CORTÁZAR, 1982, p. 20).

\footnotetext{
${ }^{2}$ No presente texto, optamos por manter a grafia original no inglês. Percebi que os termos correspondentes em português - pessoa, personalidade, eu, caráter, ego - não expressam integralmente o significado original do termo self.
} 
Quis trazer esse conto para transformar em imagem a noção do trabalho percorrido na busca por respostas possíveis a partir de uma dúvida e, também, a sensação causada de que se tem que solucionar o problema apresentado. Além disso, a emoção da angústia que o percurso carrega ao deparar-se com o fato de que não existe um fim último determinado e completamente satisfatório. O que existe é a formação de uma opinião, que pode levar a mais bifurcações de pensamento.

Esse processo de inquirição, que perdura durante toda a pesquisa, me fez buscar por autores e pensamentos das teorias da comunicação, da semiótica, da sociologia, da história e da história cultural. Além disso, as próprias recordações e experiências me levaram a percorrer caminhos e descaminhos, linhas de convergência e separação que compartem de uma mesma explicação. Também fui atrás de opiniões de pessoas, conversei, entrevistei mães. Algumas bifurcações me levaram a encruzilhadas distantes, e tive de voltar para refletir desde outro ponto, que não me deixasse perder o rumo.

Nesse percurso, procurei inicialmente entender o sentimento que me percorria e que me fazia questionar. Tal sentimento vinha da tentativa de compreender o isolamento e depois a comunhão pelo ato de comunicar. Que sentimento é esse de pertencer a uma comunidade por conta de uma memória comum?

Pensando em tal compartilhamento de memórias, pensando ainda que elas não são apenas comuns, mas também individuais, vi no conceito de self de Mead e de Peirce- que é um tipo de mente autônoma dotada da capacidade de autoconsciência - algo muito interessante para meu percurso. A partir dele, pode-se compreender que nos constituimos na ação e interação com as pessoas e com o mundo no decorrer da vida. O self desenvolve-se dentro de processos de socialização, sem perder de vista a individuação.

À medida que nos formamos por processos de comunicação, internalizamos, formulamos e reformulamos pensamento, opiniões, dúvidas, processos de inquirição. Nesse ínterim, o self propicia pensar que cada indivíduo tem algo de próprio que o distingue dos demais. Ao mesmo tempo existe uma esfera de ideias e memórias compartilhadas entre os selves para que possam ser membros de uma comunidade. Assim, apenas podemos nos desenvolver e desenvolver nossas memórias em conjunto com os outros. Na interação, formulamos hábitos. Nesse ínterim as esferas do social e do individual se entrelaçam e são elementos de constituições mútuas.

Continuando os questionamentos, o conceito de semiosfera, de Lotman (1996), veio me ajudar a enxergar as memórias individuais e comuns como sistemas organizados em que a formação de sentido ocorre por meio de diálogos entre signos, que acontecem entre 
semiosferas e no interior de cada uma. Pode-se a partir daí pensar em intercâmbios de signos que geram outros signos, em processos de semiose, em que um representamen está em relação a um segundo, seu objeto, e é capaz de gerar um terceiro, seu iterpretante.

As memórias, que vão criando forma pelo desenvolvimento da semiose; ou seja, pelo desenvolvimento do self, advêm de várias esferas de atuação do sujeito com o social. A partir da observação do cotidiano, nota-se que as relações inter e intrapessoais vividas são o que alimentam a dinâmica e a experiência dos significados possíveis. Nesse ínterim o próprio entendimento do significado da palavra comunicar é instigante: refletir sobre os compartilhamentos de experiências e memórias e sobre a formação de hábitos decorrentes de processos de inquirição formados na socialização é refletir sobre a comunicação.

A palavra comunicar aparece no século XIV em português, a ela se referem comunicativo, comunicável, comunicante, comunicabilidade, comunicação, comunicado, comunicador, incomunicação, incomunicável. Ela deriva do latim Communis, que é o mesmo que comum. Comunico ou comunicare é o mesmo que por em comum, tomar parte em, comunicar, comungar.

Communis deve ter significado inicialmente <<que desempenha com outros os mesmos encargos >>;compare-se, v. gr., negotium comune, <<empresa para a qual concorrem todos com sua contribuição $>$. Mas é com o significado de <<comum>>, em oposição a proprius, que ocorre já na língua arcaica, correspondendo ao adj. gr. (MAGNE, 1961, p. 182)

Essa última diferenciação assinalada por Magne entre o próprio e o comum é pressuposto importante para esta pesquisa. O suposto isolamento - já que em fato estamos sempre em relação - e, em seguida, a comunhão pelo ato de comunicar é ponto motriz de desenvolvimento da análise que faço. Ao revivermos em comunhão estamos revendo algo em nossos selves.

Nesta dissertação, as dinâmicas encontradas nos processos de trocas simbólicas entre os selves surgem como dimensões que constituem a cultura a partir de processos comunicacionais. As trocas decorrentes de dinâmicas comunicacionais, mediáticas ou não, possibilitam relações intra e interpessoais que fazem reconfigurar o estar no mundo. $\mathrm{O}$ conceito de mãe é desenvolvido nessas e dessas dinâmicas.

Entendo os fluxos comunicacionais sendo configurados pela interação entre memórias de filmes, novelas, séries, redes sociais, imagens e vídeos disponibilizados na internet, relações familiares, elementos históricos, literários, artísticos, religiosos, etc. As representações de mãe que aparecem em relatos, descrições, pinturas, novelas vão sendo 
modificadas em relações do self. Dessa forma, releituras ou reelaborações são possíveis graças a movimentos que vão do indivíduo para o social e do social para o indivíduo, e também do indivíduo para as coisas do mundo e delas para o indivíduo - esse é o próprio processo de constituição do self.

\section{2. $O$ caminho da questão-problema}

Gostaria de retomar a questão-problema: como o self mãe cria forma? A partir dela, penso em formações de sentido que vão sendo geradas pela/ na constituição do self mãe. Como o self mãe é engendrado por meio de processos de semiose? Como, por processos de modificação da memória - da semiosfera - o self mãe vai sendo formado? Penso em "cria forma" e não "se forma" porque traz uma ideia mais ampla de continuidade do processo de formação.

Além disso, penso em "self mãe" e não "self da mulher enquanto mãe" porque a segunda concepção dá a entender que existiriam dois selves, um referente à mulher e outro à mãe; quando em verdade, trata-se de um self, o da mãe. Após o nascimento, a mulher deixa de ser uma mulher sem filhos e passa a ser mãe, isto é, se ela assumir o papel da maternidade.

Fiquei um tempo refletindo sobre o modo de enunciar minha questão-problema porque não queria trazer a ideia de mulher = mãe, queria deixar claro, de algum jeito, que existe uma mulher para além do papel de mãe, mesmo após o nascimento do(a) filho(a). No entanto, investigo especificamente o que acontece à mulher quando ela passa a ser também mãe. Nesse caso, o que aconteceria no self dela com essa nova experiência? E o self é um só, que não se divide. Portanto, para investigar esse aspecto de sua vida, optei pelo modo "self mãe": como o self mãe cria forma?

Para responder a essa questão, retiro inferências que me levam a caminhos possíveis: o self mãe cria forma por processos de semiose. O que são esses processos de semiose? O que acontece neles? Como posso analisá-los? Tais desenvolvimentos do self mãe acontecem por meio de inquirições que geram hábitos. Os hábitos não são formulados de modo isolado, dependem do social e acontecem no/pelo entendimento do conceito de mãe. Vindo por esse caminho, como eu poderia fazer para clarear o conceito de mãe?

Para esse clareamento, fiz entrevistas com mães e conversei com pessoas sobre a maternidade e o conceito de mãe. O desenrolar das entrevistas e a dissertação como um todo se deram a partir das seguintes categorias de análise: memória-esquecimento e isolamento- 
comunhão. A primeira dela entra porque o self se constitui no tempo, em contrução da memória. A segunda surge porque o self é social.

Esta dissertação divide-se em Introdução, Pragmaticismo, Capítulos 1, 2 e 3, Considerações Finais e Referências Bibliográficas. A seguir, apresento um breve resumo de cada um dos capítulos:

O primeiro deles, "As categorias universais e entrada do objeto", expõe algumas referências de signos icônicos que ajudam a compreender possíveis hábitos formulados na cultura na acepção do conceito de mãe. Além disso, o capítulo exibe as três categorias de Peirce - primeiridade, secundidade e terceiridade - a fim de examinar os processos de semiose que se dão no self no entendimento do conceito "mãe".

O segundo capítulo, "Pensando o self mãe", trabalha de forma mais aprofundada o conceito de self de Peirce e de Mead, expondo relações do indivíduo e do social em processos de semiose que acontecem na memória. $\mathrm{O}$ texto também aborda a divisão dual e hierárquica de sexo e gênero, pensando em sua construção histórica e em como tal divisão é determinante na constituição do self mãe.

O terceiro, "As formações de sentido no self mãe", aborda as formações de sentido na memória, pensando-a como uma semiosfera - conceito de Lotman. O texto trabalha os mecanismos de produção de sentido na memória do self mãe a partir de conceitos de ícone, índice e símbolo e da concepção da personalidade como coordenação de ideias.

O próximo título, denominado Pragmaticismo, enfoca a metodologia empregada nesta dissertação para a análise da questão-problema. O Pragmaticismo serve de caminho e guia para o desenvolvimento de toda a pesquisa. 


\section{PRAGMATICISMO}

Oia quebra gereba Oia quebra, oia quebra

Eu quero ver quebrar

Oia quebra daí

Oia quebra de lá

Vou quebrar tudo hoje Amanhã quem que quebra.

(Corrido de Capoeira Angola)

A definição da metodologia empregada nesta dissertação foi pensada com cuidado porque ela é determinante para todo o processo de entendimento do objeto de pesquisa. Consiste na reflexão sobre as decisões e caminhos tomados em acordo com a questãoproblema, que nos impulsiona a fazer o recorte epistemológico - cruzando dimensões abstratas e concretas, delimitadas a partir do empírico e do teórico solicitados pela pesquisa. Além da reflexão, a metodologia é também o que define os passos dados na pesquisa.

O caminho metodológico busca descobrir as interfaces do objeto de pesquisa, sabendo que a realidade estudada está sempre em movimento. No trajeto desta investigação, o caminho percorrido sofre intensas modificações por meio da constante reflexão sobre o que se pesquisa. A cada nova questão interposta, caminhos abrem-se para novos horizontes possíveis.

Procedendo ao trajeto da pesquisa, a cada passo busco ampliar o entendimento da dúvida. Nesse ínterim, deixo que o pensamento me leve a buscar leituras, conceitos e ideias de áreas que não a Comunicação Social, moldando a interdisciplinaridade, aproveitando da interdependência própria à ciência. Essas escolhas são resultado de processos reflexivos epistemológicos e metodológicos.

Enfim, quando se pergunta pela metodologia do trabalho científico, a resposta vem sobre sua orientação geral, a tendência teórica que guia o processo de pensamento, a maneira como os pensamentos vão se apresentando e as técnicas particulares, o procedimento. Esses níveis entrecruzam-se à medida que reflito sobre as questões que surgem. Nesse sentido, o objeto resulta do processo de interseção das reflexões teóricas com o factual. E a maneira 
como essa interseção se dá é apreendida pela metodologia empregada, no caso deste trabalho específico, o Pragmaticismo de Peirce.

Nesta dissertação, o objeto constitui-se de substrato móvel e fluído: as formações de sentido no self mãe. Na procura por respostas possíveis me vi diante da interpenetração de termos, que serviram de categorias de interpretação, as quais foram mencionadas na introdução: a memória e o esquecimento, e o isolamento e a comunhão.

\subsection{Dúvida e crença}

Peirce em "A fixação da crença" (1877) ressalta que conseguimos diferenciar o ato de querer questionar algo do ato de querer pronunciar um julgamento, e isso acontece porque existem distinções entre a sensação de duvidar e a de acreditar. Mas não é apenas por meio desse viés que conseguimos fazer a diferenciação entre a dúvida e a crença, porque também existe uma diferença prática. Ou seja, o sentimento da crença é uma indicação de que existe estabelecido, em nossa natureza, algum hábito que determina nossas ações.

A dúvida, por outro lado, nunca tem tal efeito, ela é um estado de desconforto e insatisfação do qual lutamos para nos livrar e passar ao estado de crença. Este último é calmo e satisfatório e, portanto, não nos leva a desejar evitá-lo, pelo contrário, costumamos agarrarnos a ele.

A dúvida estimula-nos a agir até que é destruída em consequência de uma nova crença gerada. A opinião gerada a partir daí, mesmo que pareça que tenha de ser verdadeira, não necessita de fato ser. Assim que uma crença firme é alcançada ficamos satisfeitos, sendo ela verdadeira ou falsa. "A produção da crença é a única função do pensamento." (PEIRCE, 1878, p.6).

O desenvolvimento de minha opinião sobre o que estou estudando decorre da busca que faço das crenças encontradas, formuladas e reformuladas pelas mulheres - a partir de processos sociais - ao se verem em uma nova realidade, a de serem mães. Procuro pelas experiências de cada uma das entrevistadas, que estão imersas em um mundo forjado por representações do que é ser mãe - em pinturas, livros, filmes, imagens...

Como mencionei na introdução, a pesquisa começa sempre com uma dúvida sobre uma hipótese. É essa problematização que permite ao pensamento crescer, fazendo da investigação, para além de um inventário de dados, ação criativa motivada pelo desejo de conhecer. Minha hipótese inicial era de que existiriam possíveis hábitos comuns entre as mães que participariam da constituição do self delas. Tento entender a partir daí as formações de 
sentido que acontecem nas constantes reconfigurações das mulheres, dentro da ideia que têm de maternidade, ao se perceberem enquanto mães.

Nesta dissertação, trabalho com o pragmaticismo de Peirce pensando em entender o conceito de mãe nas conversas do dia-a-dia, nas entrevistas feitas e nos artefatos e imagens encontrados na cultura. O pragmaticismo é um método formulado para clarear os conceitos a partir dos hábitos que produzem.

Dentro da perspectiva desse método, Peirce (1877) traz duas categorias para a noção de dúvida: a dúvida genuína e a dúvida de papel. Segundo ele, deve existir uma dúvida real e viva para que a mente se afadigue em busca da crença. Esse ato, alimentado pela curiosidade, está envolto pelo "apetite de emoção". A dúvida genuína passa por sentimentos, por sensações, pelo corpo inseparável da mente. Isto d'Ors (1995, p. 59) nomeia “a inteira atividade do espírito".

Pensando sobre a ideia de dúvida genuína como a curiosidade autêntica e espontânea de descobrir, que impulsiona à investigação. Pensando também que esse impulso motiva não apenas a mente, mas o corpo todo como um sistema sensível aos estímulos vindos do mundo, minha pesquisa passa por certa identificação com as mães, que vivem no dia-a-dia a situação que tantas vezes encontraram - e ainda encontram - em imagens midiáticas e em objetos plásticos: a mulher tornar-se mãe.

Os hábitos comuns que posso encontrar nessas mulheres ao entrevistá-las são o que procuro. Minha questão, que foi posteriormente reformulada era: que formações de sentido aparecem para reconfigurar constantemente os selves das mulheres enquanto mães?

Ela se modificou para a configuração que apontei na introdução: como o self mãe cria forma? Entendi que já está pressuposto nas configurações do self que elas decorrem de formações de sentido. Além disso, existe o outro lado, o self também é responsável por criar sentido. Portanto, ele cria forma pelo/no aparecimento de sentido.

Dito isto, gostaria de passar para o conceito de mãe. Percebe-se que não se trata de todas as mães. Entendo aqui "mães” dentro da concepção de tipo ideal de Max Weber (1999). De acordo com ele, pode-se analisar uma situação social a partir de generalizações que orientam a investigação. Trata-se de uma utopia para a estruturação dos conceitos.

Obtém-se um tipo ideal mediante a acentuação unilateral de um ou vários pontos de vista, e mediante o encadeamento de grande quantidade de fenômenos isolados dados, difusos e discretos, que se pode dar em maior ou menor número ou mesmo faltar por completo, e que se ordenam segundo pontos de vista unilateralmente acentuados, a fim de formar um quadro 
homogêneo de pensamento. Torna-se impossível encontrar empiricamente na realidade esse quadro, na sua pureza conceitual. (WEBER, 1999, p. 106).

Nesse ínterim a busca da pesquisa consiste também em determinar, em cada caso particular, a proximidade ou afastamento entre o empírico e o quadro ideal. Em que medida, portanto, as mães entrevistadas podem se aproximar e se afastar desse conceito de mães que trabalho aqui, pois o que procuro são os hábitos entre elas e não as diferenças. O tipo ideal da mãe deve ser cuidadosamente aplicado na investigação e na representação.

Com esse esclarecimento, posso voltar a falar de como entendo a dúvida. Percebo-a como a curiosidade por descobrir algo que ainda não se sabe, uma sensação de incerteza que provoca a sair em busca do entender, de desorganizar o mundo, que parecia dado de antemão. "O homem que conhece matérias de curiosidade exerce uma violência contra a natureza, apresentando à sua própria investigação novos objetos, problemas supérfluos que o curso natural da vida não lhe havia apresentado." (d'ORS, 1995, p. 56).

O conhecimento nascente carrega em si a liberdade de imaginar e de olhar por outros lados o objeto. "Este momento da iniciação na liberdade é precisamente aquele em que se impõem ao sujeito leis novas, leis da arte." (d'ORS, 1995, p. 58). Para d'Ors (1995, p. 61), com nossa curiosidade, se a diversidade e a irracionalidade chegassem a faltar no mundo, seríamos capazes de inventar diversidades fictícias e novas irracionalidades para que a ciência não permanecesse estacionária.

Segundo Peirce (1878, p. 11), o significado de qualquer coisa real no mundo se encerra nos hábitos que ela produz, ou seja, para constituir o significado, temos que determinar os hábitos. Além disso, a noção do hábito depende de quando ele começa e de como ele nos leva a agir. No que toca ao quando, qualquer estímulo para a ação provém da percepção; no que toca ao como, todo o objetivo da ação é o de produzir um resultado sensível.

Para Peirce (1878, p. 12), a ideia que se tem de qualquer coisa é a ideia que se tem dos seus efeitos sensíveis. Quando falamos que uma força existe é porque sabemos quais são os efeitos que ela provoca. A ideia que vem à mente ao pronunciarmos a palavra força afeta nossas ações, e as ações não têm referência à força a não ser através dos efeitos concebíveis dela.

O mesmo se dá em relação à maternidade. Busco pelos possíveis hábitos encontrados nas mães por conta do entendimento que têm a respeito da maternidade. As ações são os 
hábitos. E os hábitos aparecem em formações de sentido no self. Todas as sensações que as coisas reais provocam irrompem na consciência na forma de crenças.

\subsection{O conceito de musement}

Pensando nessa ação do pensamento excitada pela curiosidade, que nos provoca a imaginar, é interessante notar como na pesquisa - ao deixar-se encantar pelas coisas ao redor, ao permitir que o cotidiano adquira significações outras quando se entrelaça ao objeto de pesquisa - conseguem-se relações variadas e, muitas vezes, impressionantes. Diálogos possíveis porque deixamos que aconteçam, sem nos fixarmos em um percurso rígido, sério e limitado.

A limitação da criatividade é causada, muitas vezes, pela tentativa forçosa de manterse sério, impedindo a espontaneidade do acaso do cotidiano. Nesse processo, recordo a frase de Vigotsky (VIGOTSKY, 1997 apud RUSSI, 2016, p. 165) "No intuito de explicar e compreender a experiência, é necessário ir além de seus limites; é necessário esquecê-la por um minuto e separar-se dela".

Esse seria o estado de musement de que fala Peirce sobre os processos criativos, que nos permite surpreender-nos com os alcances possíveis da imaginação da mente que busca integrar a filosofia à vida (D’ORS, 1995, p. 18). É essa liberdade, que vai além do ato de rever teorias, que faz com que não finjamos duvidar filosoficamente daquilo que não duvidamos em nossos corações. (PEIRCE, CP 5.265). ${ }^{3}$ A única lei necessária para o jogo da criação e do pensamento é a lei da liberdade (PERICE, CP 6.460).

Suba ao seu bote do musement, empurre para dentro do lago do pensamento e deixe a brisa do céu inchar sua vela. Com os seus olhos abertos, desperta ao que está ao seu redor ou dentro de si e inicie conversa consigo mesmo; para isso é toda meditação." (CP 6.461).

No trajeto desta dissertação, o pensamento instiga-se fatidicamente pela dúvida, apontando desdobramentos de ideias, que se interseccionam e se desenvolvem. Percebem-se nesse percurso alguns pontos de apoio, atingidos por esse desencadeamento das ideias.

\footnotetext{
${ }^{3}$ Nesta dissertação, as seguintes abreviaturas são utilizadas para fazer referência à obra de Peirce: CP: abreviatura de Collected Papers de Peirce, seguida do volume correspondente e do parágrafo, conforme a referência: The Collected Papers of Charles Sanders Peirce. Vol. I-VIII, C. Hartshorne, P. Weiss \& A. Burks (eds.). Cambridge, MA: Harvard University. Press, 1931- 1958.

MS: Manuscritos citados como MS, seguidos pelo número de página, conforme a referência: OBIN, Richard S. Annotated catalogue of the papers of Charles S. Peirce. Amherst: University of Massachusetts, 1967.
} 
Quando se atinge algum desses pontos, o pensamento faz uma espécie de bifurcação e passa a caminhar a partir dela. São pontos de desenrolar de ideias que culminam em um mesmo caminho, o caminho traçado pelo objeto.

Esses pontos de apoio a que me refiro lembram um movimento da capoeira angola denominado "Chamada", que adquire vários sentidos, a depender de como se utiliza dela. Um deles é a acepção de que é um momento de virada do jogo, quando um jogo que está meio de vagar ou fraco pode ficar mais forte e mais desafiador. Ao ser aplicada logo após um golpe certeiro, ela pode significar o instante em que se desafia o outro jogador a encarar um jogo mais duro.

A "Chamada" pode ser feita de distintas formas, em uma delas, um dos jogadores levanta o braço direito para que o outro venha segurar-lhe a mão. A outra mão segura o cotovelo do jogador opositor para que não haja perigo de alguém receber, de repente, uma cotovelada. Os dois andam juntos, como em uma dança, para frente e para trás, até que se desfaz o laço que os une e o jogo prossegue de modo diferente.

Curioso fazer essa relação porque a impressão que se tem é que o pensamento deixa de ser apenas livre e passa a ser também desafiador: desafiador para quem pensa e escreve e para quem lê e reflete a respeito. Há pouco tempo foi publicado na internet um relato do mestre de capoeira angola Cobra Mansa em que ele conta sobre a defesa de dissertação de mestrado de uma capoeirista.

Na banca, por serem alunos de capoeira, os doutores presentes, como em uma roda, usavam termos dos capoeiristas. Os comentários sobre a dissertação eram falados em forma de movimentos da capoeira. Um dos doutores da banca usou uma frase: "não entendi a sua "Chamada". Outro doutor falou: "estava esperando um jogo mais duro". "Você fez uma 'Chamada' e eu fui e fiquei esperando como você ia sair". Foi a partir desse relato que fiquei instigada pela comparação que faço aqui, que me leva a me sentir provocada por cada "Chamada" da dissertação.

\subsection{A máxima pragmaticista}

Cada um desses vértices que apoiam determinada ideia caminha, nesta dissertação, conforme já assinalei, para uma tentativa de clarear o conceito "mãe". Com essa ideia de clarear os conceitos, Peirce enuncia a máxima pragmaticista: "considere quais os efeitos que possivelmente podem ter a influência prática que o objeto de sua concepção tem. Neste caso, 
sua concepção desses efeitos é o TODO de sua concepção do objeto.” (PEIRCE, 2008, p. 291).

\begin{abstract}
Uma concepção, isto é, o teor racional de uma palavra ou outra expressão reside, exclusivamente, em sua concebível influência sobre a conduta da vida; de modo que, como obviamente nada que não pudesse resultar de um experimento pode exercer influência direta sobre a conduta, se se puder definir acuradamente todos os fenômenos experimentais concebíveis que a afirmação ou negação de um conceito poderia implicar, ter-se-á uma definição completa do conceito, e nele não há absolutamente nada mais. Para esta doutrina, o presente autor inventou o nome de pragmatismo ${ }^{4}$. (PEIRCE, 2008, p. 284).
\end{abstract}

Da mesma forma, as nossas concepções de um objeto (seu significado, ou a ideia que temos dele) são os efeitos que concebemos ter o objeto, e esses efeitos devem ser tais que poderiam concebivelmente ter consequências práticas. Nesse sentido, o pragmaticismo é trazido para esta dissertação como ação de entendimento ou interpretação que permite conceber o conceito de mãe a partir dos efeitos que possivelmente podem ter a influência prática que o objeto dessa concepção tem. Essa concepção aparece nas falas das entrevistadas, nas representações, nas falas cotidianas.

A versão jamesiana da máxima difere da original peirceana de 1878. James expandiu a máxima de Peirce ao identificar nossa concepção de um objeto com os efeitos que o objeto "pode envolver". No entanto, muitas vezes os objetos de nossa concepção "envolvem” efeitos que não consideraríamos ser parte de nossa concepção desses objetos. " $\mathrm{O}$ ato de arrancar a bolsa de alguém pode envolver o efeito de tropeçar e arranjar um nariz quebrado, mas isso não faz o arranjar um nariz quebrado parte de nossa concepção de roubar uma bolsa." (WAAL, 2007, p. 53).

Além disso, segundo Waal (2007, p. 62), James restringiu a máxima peirceana ao menos em dois aspectos. Primeiro, confina o significado de um pensamento ou proposição a sensações e reações particulares. Segundo, exige que esses efeitos particulares sejam experimentais. Para Peirce, o significado de uma ideia está imbricado aos hábitos que ela ocasiona - que são gerais, e não particulares, por isso, procuro por eles nas entrevistas e não pelo que as respostas têm de particulares. Também se pode afirmar que os hábitos não são efeitos experimentais. Vamos à máxima jamesiana:

\footnotetext{
${ }^{4}$ Peirce concebeu o conceito de pragmatismo, contudo, devido ao uso utilitário e amplamente disseminado nos estudos de Willian James e de Ferdinand Schiller, cujos sentidos eram diferentes dos propostos inicialmente por Peirce, este último abdica da palavra e adota o termo pragmaticismo.
} 
Para atingir clareza perfeita em nossos pensamentos de um objeto [...] precisamos somente considerar quais efeitos de uma espécie concebivelmente prática o objeto pode envolver - quais sensações devemos esperar dele, e quais reações devemos preparar. Nossa concepção desses efeitos, então, é para nós o todo de nossa concepção do objeto, na medida em que essa concepção tem alguma significância positiva (JAMES, 2001, p. $348)$.

Nesse sentido, é importante que se destrinche as noções de geral e particular, referentes aos dois teóricos. James está interessado no indivíduo que acredita que o pensamento ou a proposição filosófica são verdadeiros. Para ele, toda a função da filosofia deveria ser descobrir que diferença fará para pessoas específicas e determinadas, em instantes definidos de suas vidas, se uma ou outra fórmula de mundo é verdadeira. Em minha análise, e para Peirce, "o real é aquilo cujas características são independentes do que alguém possa pensar que elas sejam" (PEIRCE, 1878, p. 19).

Além disso, a máxima pragmaticista nada diz sobre experimentos singulares ou sobre fenômenos experimentais singulares, pois o que é real está para além de um momento específico. A realidade existe como potência de acontecimento futuro, que dificilmente pode ser singular. A máxima fala das espécies gerais de fenômenos experimentais. Nesse sentido, o significado de toda proposição está no futuro.

Um fenômeno experimental é o fato afirmado pela proposição de que a ação de certa descrição terá certa espécie de resultado experimental; e resultados experimentais são os únicos resultados capazes de afetar a conduta humana. [...]. Sempre que uma pessoa agir intencionalmente, age sob a crença em algum fenômeno experimental. Por conseguinte, a soma de fenômenos experimentais que uma proposição implica constitui todo o alcance deste fenômeno sobre a conduta humana. (PEIRCE, 2008, p. 293)

Para o pragmaticismo, a riqueza dos fenômenos reside em sua qualidade sensória. Ele se presta a definir os equivalentes fenomenais das palavras e ideias gerais. E o geral é da natureza de uma palavra ou signo. "a generalidade é, com efeito, um ingrediente indispensável da realidade." (PEIRCE, 2008, p. 294).

No conto de Jorge Luis Borges (2015) intitulado Funes el memorioso, o personagem não era capaz dessa generalização, em seu mundo não havia outra coisa a não ser detalhes imediatos. "Não apenas lhe custava compreender que o símbolo genérico cachorro abarca tantos indivíduos díspares de diversos tamanhos e diversa forma; lhe incomodava que o 
cachorro das três e catorze (visto de perfil) tivesse o mesmo nome que o cachorro das três e vinte (visto de frente)." ${ }^{5}$ (BORGES, 2015, p. 133).

Por se preocupar com o geral, isto é, com a regularidade dos eventos, e não com eventos particulares, o pragmaticismo preza que os experimentos não sejam vistos como apreendidos no laboratório no passado, mas como cadeias de ocorrências regulares. Toda série relacionada de experimentos constitui, portanto, um experimento coletivo singular.

Nesse sentido, o significado consiste em fenômenos experimentais, que não tratam de um evento particular qualquer que realmente aconteceu a alguém no passado morto, mas de eventos que seguramente acontecerão a todos que, no futuro ainda por ocorrer, preencham certas condições. (PEIRCE, 2008, p. 292). Dessa forma, e por isso, as observações do cotidiano e as entrevistas que faço ajudam a perceber regularidades, crenças que aparecem em comum nas falas e ações, que permitem que as mães aproximem-se do tipo ideal de Weber.

A máxima pragmaticista torna-se interessante para a análise da formação do self mãe porque procuro, nas falas das entrevistadas, por condutas que se mostram na concepção que elas têm do conceito "mãe". As condutas de vida são efeitos que recebem influência prática da concepção do conceito "mãe". Nesse caso, a concepção de tais condutas constitui o todo da concepção do conceito. Essas condutas resultam em história e são, também, resultado dela; ou seja, os hábitos são constituídos pela/na memória social.

\subsection{A coleta de dados}

A partir da concepção da máxima pragmaticista, fui atrás de falas que me trouxessem efeitos de conduta. Quando questiono “como o self mãe cria forma?”, em acordo com o que venho falando, estou implicando com isso que os selves são reposicionados, após o nascimento do bebê, a partir de uma noção que se tem do que é ser mãe. Essas experiências podem vir na forma de narrativa de fatos do cotidiano, nas expressões de sentimentos, ou de modo mais direto em respostas direcionadas pela pergunta: "o que vem a sua mente quando pensa na palavra mãe?”.

Inicio o trabalho fazendo o que Lakatos (2010, p. 178) chama de observações do cotidiano, que são feitas em ambientes corriqueiros, registrando-se os dados à medida que

\footnotetext{
${ }^{5}$ Tradução livre da autora do original em espanhol: "No sólo le costaba compreender que el símbolo genérico perro abarca tantos individuos dispares de diversos tamaños y diversa forma; le molestaba que el perro de las tres y catorce (visto de perfil) tuviera el mismo nombre que el perro de las tres y cuarto (visto de frente)." (BORGES, 2015, p. 133)
} 
acontecem, sem preparação prévia. Nesse gesto, identifiquei falas, comentários, lembranças ${ }^{6}$ (essa não foi apenas uma etapa da pesquisa, mas passei a fazer tais observações durante todo o percurso).

Utilizar conversas do cotidiano como fonte de informação é o mesmo que estar em campo durante todo o tempo da pesquisa. Ou seja, sempre que surgia o tema maternidade nas conversas, eu estava em campo. Registrei conversas em sala de aula, em festas, no trabalho, no contexto da capoeira, em ônibus, clínica, etc. O número de pessoas, nível de escolaridade, idade e sexo dos participantes obviamente variava de uma situação à outra.

Presenciei e participei de situações que acabaram se perdendo por conta da dificuldade de registro (não registrar durante a conversa ou logo em seguida, por exemplo). $\mathrm{Na}$ maioria das situações o registro foi feito com o que eu lembrava, pois o uso de algo que gravasse mostrou-se problemático: algumas conversas eram tão fugazes que não havia tempo hábil para ligar a gravação. Além disso, a espontaneidade do momento se perderia nessa atitude.

Comecei, após algumas dessas observações, o processo de entrevistas. Ao pensar na melhor forma de fazê-las, a afim de que compusessem esta dissertação e lhe servissem de guia, fiz entrevistas na forma qualitativa, visto que o interesse não era por números - maior quantidade de mulheres que pensam de determinada forma, por exemplo - mas sim pelo conteúdo particular de cada uma, a fim de que constituíssem uma totalidade de possíveis hábitos comuns. Hábitos que se esperavam expressos nas falas. As entrevistas, nesta dissertação, têm caráter apenas experimental. Elas são uma forma de compreender os processos de formação de sentido, e não são trazidas para retirar respostas conclusivas.

Nesse sentido, as questões iniciais eram no estilo Entrevista Narrativa: técnica qualitativa que permite explorar o assunto por meio da busca por informações, percepções e experiências das entrevistadas. Com ela pude entender melhor o contexto de formação de certo núcleo familiar das pessoas que falavam. Pude perceber, também, referências como classe social, local de trabalho, idade, lugar de nascimento e um pouco de suas histórias de vida. Essa técnica permite analisar respostas pelo caráter intenso que podem ter devido às

\footnotetext{
${ }^{6}$ Nesta dissertação, para ir-se tecendo o conceito de memória e o de lembrança, entendo que memória refere-se aos processos de constituição de sentido encadeados por uma lembrança ou um mote no instante em que se lembra. Enquanto a lembrança é a descrição, o relato, a narrativa de um fato; a memória são os diálogos que se formam na mente, entre signos e textos, que originam novos sentidos e remetem a todo o contexto que circundava o fato lembrado. Assim, fazendo paralelo com Bosi (2003, p. 40), a memória é o que constitui o self como único e ao mesmo tempo multável e a lembrança são as distrações do presente que originam ideias e pensamentos que remetem a outro momento no tempo cronológico.
} 
experiências pessoais de cada uma, pois não procura respostas em forma de representações estatísticas. Com ela pude resgatar algumas lembranças das mães.

Outras questões eram mais explícitas em relação ao conceito de mãe, envolvendo perguntas relacionadas à maternidade, ao amor materno e à relação entre ser mulher e ser mãe. Além disso, determinei perguntas que trouxessem percepções a respeito de modificações ocorridas ao longo da experiência como mãe e também sobre possíveis diferenças entre esse conceito antes e depois da gravidez. Em suas falas, as mulheres expuseram lembranças a partir de interpretações feitas por elas de suas memórias.

Essas entrevistas não são vistas como dados isolados e observados à distância, porque são também resultado da interpretação e reconstrução minhas como pesquisadora em diálogo com a realidade. Ao analisar as falas, procuro entender cada uma das entrevistadas em um processo complexo que envolve identificação mútua, de uma conversa surge algo novo. Minhas interpretações desenvolvem-se à medida que contribuo para a significação dos elementos que se apresentam a partir das histórias de vida. As narrativas manifestam e expressam os resíduos das experiências.

Minhas interpretações seguem os quatro nodos trazidos por Russi (2010), que são apontes de autores que fazem das narrativas momentos e caminhos para o entendimento do problema de pesquisa:

Primeiramente, destaque-se que a realidade de uma narrativa refere-se ao que é real para o contador de história. Em segundo lugar, as narrativas não copiam a realidade do mundo fora delas, mas propõem representações e interpretações particulares do mundo. Em terceiro lugar, elas não estão abertas à comprovação e não podem ser julgadas como verdadeiras ou falsas; e, por último, estão sempre inseridas no contexto social-histórico.

Compreendo tais narrativas como vivências que entrecruzam as esferas individual e coletiva em experiências e interpretações próprias de cada sujeito. Retomo pelos relatos a lembrança que a princípio está escondida. Nesse percurso procuro respeitar os caminhos que as recordadoras vão abrindo em suas evocações porque são o mapa afetivo da experiência de cada uma delas. A memória é forma organizadora que dinamiza passado e presente em contexto e vivências acionados por esses relatos.

$\mathrm{Na}$ entrevista, pouco a pouco as lembranças vão tornando-se cognoscíveis mediante a voz da narradora, que realiza uma ordenação temporal pessoal, obedecendo a uma lógica afetiva, cujos motivos ignoro. Tem-se que ter sempre em mente, enfim, que contar é sempre um ato de criação, em que se recupera na própria voz o fluxo circular que a memória abre do 
presente para o passado e do passado para o presente. O próprio som nesse contexto é também forma de recriação.

Para Bosi (2015, p, 45), a expressão oral da memória de vida parece-se mais à música do que ao discurso escrito. "Há componentes musicais inerentes à expressão oral. Os sons compõem um reino flutuante e o pensamento decompõe a superfície da água em vagas e ondulações... frases, palavras,..."

$\mathrm{Na}$ conversa, muitas vezes o uso emotivo, sugestivo, musical suplanta o que está sendo dito em palavras e frases. Diante de uma narrativa, o tom da voz ou o choro sacodem os significados escondidos nas entrelinhas, relativizando o presente, que não é o absoluto para a pessoa que narra. A lembrança remete ao contexto e à situação passada reconfigurando o presente.

Para a seleção das entrevistadas, foquei na diversidade que poderia encontrar, tentando buscar pessoas de gerações, cores, naturalidades e classes sociais diferentes ${ }^{7}$, procurando a "mãe" como tipo ideal. Ao todo foram quinze primeiras entrevistas com mães. Nesse processo, entrevistei também cinco mulheres que não têm filhos, de idades e realidades diferentes. Nesse primeiro momento, esquematizei nas perguntas os seguintes tópicos de análise: isolamento-comunhão e memória-esquecimento.

Em momento posterior, voltei a entrevistar as mães, agora com perguntas focadas em possíveis hábitos que havia identificado nas primeiras conversas. Nesse sentido, trouxe como tópico principal formulador das questões o seguinte: completude-incompletude. Tais categorias serão abordadas ao longo da dissertação como foco de discussão e percepção das transformações do self mãe. Enfatiso que não confiro às entrevistas caráter conclusivo sobre possíveis hábitos. Como disse antes, para compor a discussão, dialogo com as três categorias de Peirce - primeiridade, secundidade e terceiridade -, com os conceitos de índice, símbolo e ícone, do mesmo filósofo, e com o conceito de semiosfera de Lotman.

\footnotetext{
${ }^{7}$ Essa abrangência pode parecer problemática para as estudiosas e teóricas do feminismo negro. Nessa vertente de estudos - e ativismo - alguns conceitos centrais do feminismo são problematizados ao se levar em consideração as experiências vividas pelas mães negras, que são em sua maioria ainda de classe baixa. A relação direta entre raças e classe no Brasil ainda é gritante - são resquícios óbvios dos valores da Modernidade, que serviram de alicence para a formulação do Estado-nação e para a colonização. Nesse ínterim, conceitos como família, reprodução e patriarcado são questionados pelo feminismo negro. De modo resumido, a família negra é constituída como resistência ao racismo e à colonização, o que já propicia outra relação entre o homem e a mulher. O homem negro, nesse sentido, não entra no patriarcado da mesma forma que o branco. Quanto à reprodução, observa-se que as mulheres negras ainda, muitas vezes, trabalham em casas de mulheres brancas, para cuidar de seus filhos, contribuindo, em verdade, para a reprodução da família branca. (CARBY, 2012). Ao refletir sobre isso, quase retirei as mulheres negras com medo de incorrer no erro de invisibilizá-las por não dar conta de adentrar essa discussão e sabendo que o conceito de reprodução, principalmente, é central em meu trabalho. Por outro lado, se a ideia é justamente não invisibilizar e sabendo que trago relatos pessoas de cada uma, sem a generalização que às vezes se faz, optei por trazer também suas falas.
} 


\section{Capítulo 1}

As categorias universais e a entrada do objeto

O sobrado de mamãe é debaixo d'água O sobrado de mamãe é debaixo d'água Debaixo d'água, por cima da areia, Debaixo d'água, por cima da areia,

Tem ouro, mamãe, tem prata, Tem diamante que nos alumeia.

(Corrido de Capoeira Angola)

\subsection{As três categorias universais: avanços para a compreensão da semiose}

O início do jogo de Angola é sempre uma possibilidade de ser, qualquer transformação pode acontecer a partir do aperto de mãos entre os jogadores, tudo depende do diálogo que se estabelece. O começo desta dissertação é também apenas uma possibilidade de ser, sem respostas definidas, sem conclusões nem resultados. Quero trazer como desafio a ser recobrado durante todo o percurso, novamente, a questão-problema que guia toda a pesquisa e que se reconstitui a cada retomada que faço dela: como o self ${ }^{8}$ mãe cria forma?

Pensando que tal dúvida perpassa a qualidade do amor materno e a representação das mães em obras de arte, novelas, livros e romances é interessante traçar um caminho de análise a partir das noções das três categorias universais de Peirce (CP 1.302), primeiridade, secundidade e terceiridade. Isto é possível porque a qualidade do sentimento de amor é a manifestação da primeira delas, e mãe, como conceito abstrato, refere-se à terceira - e as três estão imbricadas nos processos de semiose; ou seja, de entendimento do mundo; no caso desta investigação, elas estão em fluxos organizados para a compreensão do que é ser mãe, a partir de referenciais da cultura.

Os dois - o sentimento e o conceito - fazem parte de um mesmo processo cíclico de sentir, interpretar e comunicar. Afinal de contas, o sentimento também é comunicado mesmo que não se diga uma única palavra. O sentimento também faz parte da semiose e está sujeito a

\footnotetext{
${ }^{8} \mathrm{O}$ conceito de self de Peirce será aprofundado no próximo capítulo. Por enquanto, gostaria apenas de firmar que se trata de um tipo de mente dotada das capacidades de consciência de ser; de resistência às coisas do mundo e, portanto, de ação; e de adquiririr hábitos e livrar-se deles, também.
} 
interpretações. E é da própria natureza da semiose que algo que tenha significado seja também comunicável. Isso ocorre porque nos comunicamos por meio de signos e toda situação que signifique tem uma descrição interpretativa. Os signos estão, portanto, sempre em concordância com as regras de uma comunidade de produção semiótica de significados.

No pensamento peirciano, a noção de signo só adquire sentido com base na de semiose. E por semiose, Peirce (1981, p. 180) entende uma ação ou influência que é ou que implica a cooperação de três elementos: um signo, um objeto, e seu interpretante. Relação tripartite que não pode resolver-se em ações entre pares. A Semiose é uma ação, um processo em que algo - uma percepção, uma ideia, ou um estímulo - adquire a função de signo para alguém ou para alguma coisa.

Marinalva ${ }^{9}, 29$, descreve um pouco do que seria o amor que sente por sua filha:

Difícil descrever o que é amor, não é? O amor que eu sinto por ela é... ele cabe todos os sentimentos nele: cabe as raivas as irritações, os medos, as angústias, as alegrias, as euforias, os faniquitos, tudo isso cabe dentro do amor. Não saberia descrever o que é amor.

Pouco antes, ao ser questionada sobre o conceito de mãe, a entrevistada tinha falado do caráter da "maternidade perfeita", definida por ela como algo publicado nas redes sociais como "a fórmula da educação correta, do parto natural, da mãe disponível para o filho - que nunca grita, que nunca fala alto, que nunca usou de uma chantagem, que nunca falou da princesa”. Sobre o que é ser mãe, ela diz:

Me vem o que eu sou, me vem também uma chatice de facebook quanto à maternidade perfeita e "over e over" sobre todo mundo postando o que é a maternidade perfeita, ser uma mãe perfeita. Agora me vem tudo, as frustações, o cansaço de ser, das brigas com o filho, as brigas constantes de tentar educar, também os beijinhos, os carinhos, as brincadeiras, as risadinhas, as trocas de afeto.

Refiro-me ao amor materno e às associações que se fazem à palavra "mãe" para ir tecendo as concepções do conceito "mãe", a fim de saber como as mulheres se reposicionam no mundo, por meio de hábitos, por conta das relações que fazem ao conceito. Correspondentes às três categorias, os sentimentos e os conceitos são pertencentes aos fenômenos que envolvem a maternidade; neles, umas predominam mais que outras, umas são mais preponderantes em um aspecto do que outras, mas todas participam de cada fenômeno.

\footnotetext{
${ }^{9}$ Foram utilizados nomes fictícios afim de proteger a identidade das mulheres entrevistadas nesta pesquisa.
} 
As categorias fazem referência a fanerons - cuja descrição é a Faneroscopia; por faneron, Peirce (CP 1284, 284) significa o total coletivo de tudo o que é de qualquer forma ou em qualquer sentido presente na mente, independente de ele corresponder a qualquer coisa real ou não. Também não há possibilidade de saber quando e em que mente ele aparece.

Ao tratar das mães, trabalho com a noção de que o sentimento do amor materno e a concepção do conceito estão presentes nas mentes, em cada fenômeno que faz referência à maternidade. Ou seja, as falas das entrevistadas não são tratadas como fenômenos isolados da cultura. É por isso que o self torna-se tão interessante para esta análise. O self está intrinsecamente em conformidade com o sinequismo, pela continuidade que as coisas do mundo têm entre si.

No que se refere aos fanerons, Peirce (CP 1.285) sinaliza que alguns filósofos ingleses, à época, usavam a palavra ideia em um sentido aproximado ao que ele trazia para faneron, mas de maneira que restringia bastante seu significado. Além de darem uma conotação psicológica à palavra, tinham o costume de dizer que algumas ideias não existiam, o que tornaria inapta a comparação.

A lista de categorias - ou "arranjos filosóficos" (PEIRCE, CP 1.300) - é uma tabela de concepções retiradas da lógica em análise do pensamento e consideradas aplicáveis ao ser. A lista de Peirce cresce originalmente fora do estudo de Kant.

A primeira categoria é a força dos sentimentos, referente ao tornar-se - e não ao ser já sendo. A segunda é a força da resistência e da ação de modificar alguma coisa; e a terceira consiste na força de adquirir hábitos - de ser sendo - e de livrar-se deles também. (MS 670, 4-7 apud COLAPIETRO, 2014, p. 138).

A primeiridade é a rara faculdade de ver o que salta aos olhos tal como se apresenta, sem modificação derivada de pensamentos ou interpretações. (PEIRCE, CP 5.42). Ela é tão rara que, ao tentarmos definí-la, já se perdeu, e virou, no mínimo e mais diretamente, a secundidade. Por isso ser tão difícil descrever o que é o amor. A fala da entrevistada, mencionada antes, já é codificada em palavras, o que já traz uma transformação do sentimento puro. Ao mesmo tempo, interessante notar que a pureza do sentir é individual e não um hábito $^{10}$, mesmo que corresponda de algum modo à crença do que seja o amor materno, ou seja, ao hábito que se traduz do sentimento.

A primeira categoria é a qualidade de sentimento sem consideração a nenhuma outra coisa. Ela é a categoria da capacidade de ser, da potência de tornar-se alguma coisa. O amor

\footnotetext{
${ }^{10}$ No terceiro capítulo desta dissertação, abordarei melhor a primeiridade, ou a particularidade nas configurações no self e em sua memória.
} 
vem, portanto, como potência, e não como algo inato e universal, que corresponda de modo inequívoco à crença que se tem dele. Cada self mãe carrega a potência pura do amor e a correspondência dele à crença.

Entre fanerons há certas qualidades de sensação, tal como a cor magenta, o odor de essência de rosas, o som de um apito de trem, o gosto de quinino, a qualidade da emoção contemplando uma demonstração matemática, a qualidade do sentimento de amor, etc. (PEIRCE, CP 1.304, 304). ${ }^{11}$

Como faneron, a qualidade do sentimento do amor aparece e desaparece da mente, mas sua relação com o hábito o torna cada vez mais presente na vida das mães. A qualidade de tal sentimento não é em si uma ocorrência - como o fato de alguém ver um objeto na sua frente é - mas é apenas mera probabilidade de acontecer - um poder-ser. O caráter do sentimento é, também, uma imaginação do que ele pode ser. E ele pode ser imaginado para alguma pessoa sem a necessidade de sua realização de fato. O que contribui para sua imaginação é a concepção que se tem dele como terceiridade.

Por ser apenas uma qualidade, o sentimento é peculiar no faneron, mas não significa que seja inerente a toda e qualquer denominação de "amor materno"; ou seja, não quer dizer que sua qualidade seja sempre a mesma para todos os selves, como em uma lei geral - como a lei da gravidade.

A segunda categoria é identificada pela luta que acontece após a primeira sensação comum a tudo que chega à mente - sensação referente à primeiridade. Essa luta é travada entre o esforço e a resistência, entre a mente e o que chega a ela. A toda ação corresponde uma reação igual.

Se em plena obscuridade sobrevém de súbito um tremendo relâmpago, você estará prestes a admitir que recebeu um choque e que padeceu sua ação, mas talvez se incline a negar que você, também, exerceu uma reação. No entanto, certamente a exerceu e lhe é inconsciente. A sensação de choque é tanto uma sensação de resistir como de padecer uma ação. O mesmo ocorre quando algo afeta os sentidos. A excitação externa chega a produzir seu efeito sobre você, enquanto que você, de sua parte, não produz nenhum efeito discernível

\footnotetext{
${ }^{11}$ Tradução livre da autora a partir do original: "Among phanerons there are certain qualities of feeling, such as the color of magenta, the odor of attar, the sound of a railway whistle, the taste of quinine, the quality of the emotion upon contemplating a fine mathematical demonstration, the quality of feeling of love, etc." (PEIRCE, CP 1.304, 304).
} 
sobre ela; e por isso a qualifica de agente, e passa por alto em seu próprio papel na reação. (PEIRCE, CP 5.45, 45). ${ }^{12}$

A segunda categoria é o que nos impede de viver em um mundo puramente imaginário e isolado. Ela é a expressão da resistência da realidade, que é construída também no social. É por isso que a imaginação do que é ser mãe não é suficiente para quando a criança nasce.

O bebê e a luta que se estabelece desde seu nascimento referem-se à secundidade, que determina que, o que era antes imaginado, é diferente de fato. Nesse sentido, nas falas das entrevistadas, há a ideia de perfeição que envolve o ser mãe e há também coisas que vão contra essa perfeição esperada - como sentimentos de raiva e de culpa; como a vontade de fugir da situação; as tentativas de impor certa educação e a frustração. Por isso o dia-a-dia e o habituar-se à nova situação envolvem tanto a tentativa de alcançar o que se espera de uma mãe quanto as resistências da própria relação que se estabelece no laço entre mãe e filho(a).

A secundidade é a noção de que algo é tal como é como sendo um segundo em relação a algo primeiro, independentemente de qualquer outra coisa, e, em particular, independentemente de qualquer lei, embora possa estar em conformidade com alguma. Ela é a reação como um elemento do fenômeno. (PEIRCE, CP 5.66).

A terceira faculdade é a generalizadora do matemático que cria a fórmula abstrata. (PEIRCE, CP 5. 43). Ela é a categoria da representação como elemento do fenômeno. (PEIRCE, CP 5.66). Algo é tal como é em virtude de suas relações com outros. Ela basta por si mesma para proporcionar a concepção de "Verdadeira Continuidade" (PEIRCE, CP 5.67) se refere ao conceito de mãe, de mulher, de maternidade.

Pela terceiridade, pode-se estabelecer uma possível relação entre mãe e mulher sem filhos a partir das respectivas associações de completude e incompletude. Como consequência disso, tem-se a acepção: mulher = mãe, porque infere-se que a mulher será mãe por conta da necessidade que se acredita tenha em alcançar tal papel social.

Como disse anteriormente, essas concepções e essas associações são as crenças, ou hábitos, que desenvolvemos para interpretar os fenômenos - que se dão nos diálogos das três categorias. A terceridade, como falado, é o que traz a generalização própria aos conceitos, ela

\footnotetext{
${ }^{12}$ Tradução livre da autora a partir do original: "If in pitch darkness a tremendous flash of lightning suddenly comes, you are ready to admit having received a shock and being acted upon, but that you reacted you may be inclined to deny. You certainly did so, however, and are conscious of having done so. The sense of shock is as much a sense of resisting as of being acted upon. So it is when anything strikes the senses. The outward excitation succeeds in producing its effect on you, while you in turn produce no discernible effect on it; and therefore you call it the agent, and overlook your own part in the reaction. (CP 5.45, 45).
} 
é o fundamento do pensamento e da comunicação. E a primeiridade é o que permite que se abandonem certos hábitos e se criem novos.

\subsection{O signo de Peirce}

A qualidade da representação das mães, que aparece em palavras, desenhos, fotos e pinturas, por exemplo, corresponde à terceiridade - isto são signos. $\mathrm{O}$ conceito de signo de Peirce é bem amplo - o próprio self também é um. Os signos estão em ação nos fenômenos, se desenvolvendo a partir das três categorias. Um signo, ou representamen, para Peirce (2015, p. 64), é um primeiro que se coloca numa relação triádica com um segundo, seu objeto, que é capaz de determinar um terceiro, ou seu interpretante; e o interpretante deve assumir a mesma relação triádica com seu objeto - formando a semiose.

A relação triádica é genuína, ou seja, os três elementos estão por ela ligados de modo tal que não existe nenhum complexo de relações diádicas. Nesse sentido, o interpretante, ou terceiro, não estabelece uma relação diádica com o objeto, mas coloca-se numa relação com ele do mesmo tipo da assumida pelo representamen. Além disso, a relação triádica na qual o terceiro se coloca não pode ser meramente similar àquela na qual se coloca o primeiro; isso faria da relação do terceiro com o primeiro apenas uma secundidade degenerada. O terceiro deve realmente constituir uma relação triádica e, assim, deve ser capaz de determinar um terceiro próprio; também deve ter uma segunda relação triádica na qual o representamen - ou melhor, a relação dele com seu objeto - será seu próprio objeto, e deve ser capaz de determinar um terceiro para essa segunda relação triádica.

Todo esse movimento acontece igualmente em relação ao terceiro do terceiro, e assim por diante, indefinidamente. Um signo é um representamen com um interpretante mental e o pensamento é o principal, ou talvez, o único modo de representação. (PEIRCE, 2015, p. 64).

Nesse sentido, a palavra mãe é representamen em relação triádica com as representações que se faz dela - que são seu objeto - em livros, pinturas, filmes, o que determina um terceiro - seu interpretante - que é o conceito do que é ser mãe. O conceito é representamen em relação triádica com um segundo, o filho ou filha que nasce; que é capaz de gerar um terceiro, o interpretante, que são interpretações que a nova mãe faz do conceito. E assim por diante... 


\subsection{A representação da mãe}

\subsubsection{A virgem Maria como representação de pureza}

Pensando nas representações que se faz das mães na cultura, e que constituem relações triádicas com o conceito "mãe" e com as reconfigurações que as mamães fazem no dia-a-dia após o nascimento do filho; neste primeiro capítulo, gostaria de trabalhar algumas das possíveis representações encontradas na cultura. Isto tomando como base alguns hábitos percebidos nas falas das entrevistadas, que fazem referência à entrega da mãe para seu(sua) filho(a) e a completude e incompletude.

Pensando no sentido de pureza que se pode atribuir à palavra mãe, escolhi a imagem da virgem Maria para esta dissertação, como uma das referências do que é ser mãe mais postas (ou impostas) em nossa cultura. Queria justificar essa escolha pensando na constituição da cultura brasileira, que é muito rica em elementos vindos de continentes diversos. A base de nossa cultura, por conta da história de colonização, é formada principalmente por referências indígenas, negras e brancas. Essa é uma simplificação enorme das diferenças culturais encontradas no território brasileiro a partir da história da constituição do Brasil como Estado-nação. Sabe-se que existem várias etnias indígenas vivendo no Brasil, que os negros vêm de vários países africanos e que os brancos que vieram para o Brasil na colonização, vieram, em sua maioria, da Europa ocidental. Essa é a simplificação com que a história do país é contada nas escolas nacionais.

Sem entrar nos méritos da formação estudantil do país, trouxe essa referência a fim de colocar o quanto a cultura brasileira é complexa e precisa ser explorada com mais cuidado. De qualquer forma, a história, como é contada, traz como cultura hegemônica para o país a cultura da Europa Ocidental, que já se transformou - tanto por elementos internos do território, quanto por outros advindos de outros países também colonizados pela Europa Ocidental, como os Estados Unidos e países da América Latina.

Pensando apenas no âmbito da religião, eu poderia trazer referências, por exemplo, das mamães orixás, presentes na religião Umbanda e no Candomblé, poderia citar Oxum, Iemanjá, Nanã, Iansã. Entretanto, essas religiões e suas imagens ainda são marginalizadas em nossa cultura, o que talvez dificulte vê-las, a partir do ponto de vista da cultura dominante, como referências de maternidade.

Para este momento, portanto, trouxe a figura da virgem Maria, pensando na representação de pureza que ela proporciona às pessoas de modo geral. Também conhecida 
como Maria de Nazaré, ela teria vivido na Galileia no final do século I a.C. e início do século I d.C.

Segundo o Novo testamento, e também está no Alcorão, ela teria gerado Jesus; sua gravidez acontece, no entanto, não por uma relação humana, mas por meio de um ato divino ${ }^{13}$. Isso ocorre quando ela estava noiva de José e aguardava o rito do casamento. Casa-se em seguida e, acompanhada pelo marido, vai a Belém, onde Jesus nasceu. O Novo Testamento começa o relato de sua vida com a anunciação, quando o anjo Gabriel apareceu a ela anunciando que Deus (aqui o Deus da crença cristã) a escolhera para ser a mãe de Jesus.

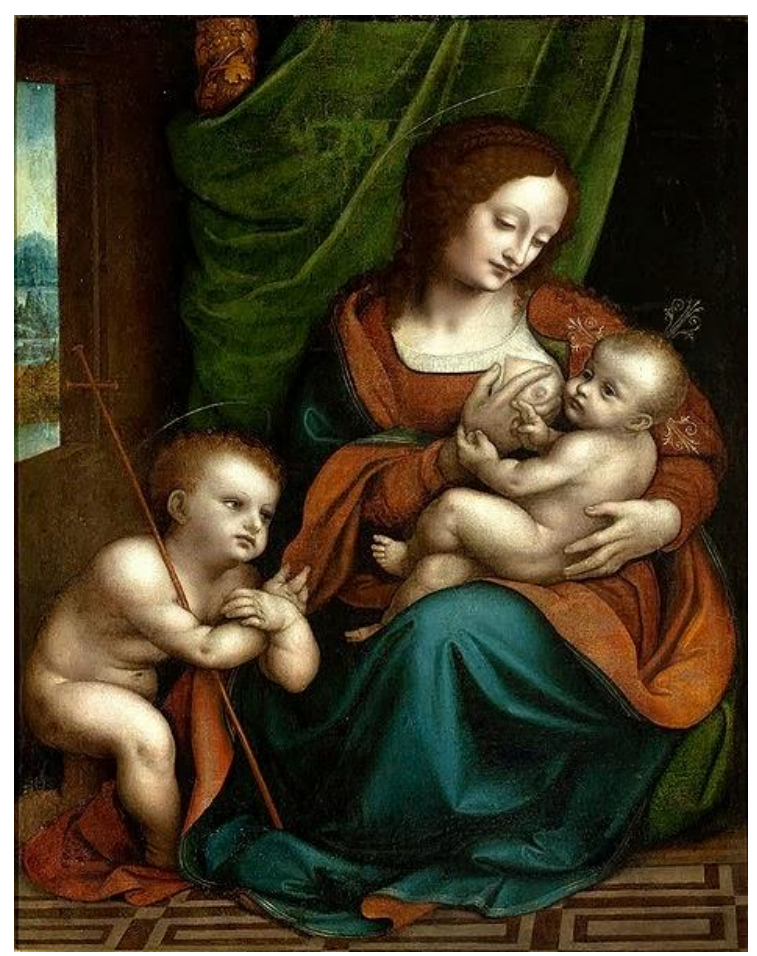

Fig. 1. Giampietrino, O menino e São João Batista criança em adoração, 1500-1520, Itália.

A Fig. 1 é a reprodução de uma das pinturas que compõem o acervo do Museu de Arte de São Paulo. Ela é obra de Giovanni Pietro Rizzoli, conhecido como Giampietrino, discípulo de Leonardo da Vinci. O seio materno exposto por uma fenda do vestido introduz a temática da Virgo Lactans, extensamente explorada entre os leonardescos (MARINHO, 2014, p. 72).

Ao adotar uma perspectiva de continuidade entre a figura e os possíveis temas do discurso, identifico os últimos como: religiosidade e maternidade. Meu foco está na maternidade e em como ela é representada. Penso nesse tema porque quero entender os

\footnotetext{
${ }^{13}$ Essa passagem é descrita em Mateus 1:16-25. Também está em Lucas 1:26-56 e Lucas 2:1-7.
} 
possíveis ícones, índices e símbolos que são conectados na constituição do conceito de mãe. Essas possíveis conexões vão sendo articuladas nos selves e pelos selves.

A pintura, como representamen icônico, é um hipoícone porque ela é um signo icônico, isto é, ela pode representar seu objeto principalmente através de uma semelhança qualitativa. Essa é uma definição em termos estritos, porque "mesmo uma ideia, exceto no sentido de uma possibilidade, ou primeiridade, não pode ser um ícone. Uma simples possibilidade é um ícone puramente por força de sua qualidade, e seu objeto só pode ser uma primeiridade." (PEIRCE, 2015, p. 64).

A noção de ícone originalmente proposta por Peirce deve ser vista saindo da mera relação de semelhança entre um signo e seu objeto. Peirce associava o ícone à primeira de suas três categorias, que está mais ligada à estética, à criatividade e à liberdade. Silbertein (2013) faz uma análise interessante sobre "graus de iconicidade" que se costuma atribuir aos signos icônicos, em uma escala que vai do mais icônico ao menos icônico.

Segundo esta perspectiva - que vem de Morris, não de Peirce -, um filme em preto e branco seria menos icônico do que um filme em cor, por reproduzir menos aspectos perceptuais do objeto a que se refere. Determinar os traços pertinentes para julgar se algo é mais ou menos icônico do que outra coisa certamente não é tarefa fácil. Mesmo que os filmes em preto e branco não tenham cor, eles podem trazer uma impressão maior de profundidade de campo por apreender uma gama mais variada de luminosidade. Seriam eles mais icônicos do que a cor neste aspecto? (SILBERSTEIN, 2013, p. 87).

Nesse sentido, a autora argumenta, conforme Bouissac ${ }^{14}$ (1986 apud SILBERSTEIN, 2013, p. 87), que, se uma pessoa diz que o preto e branco é mais icônico do que a cor seguindo tal critério e outra pessoa diz o contrário seguindo aquele outro critério, existe uma boa dose de arbitrariedade na escolha dos traços considerados pertinentes e, portanto, no próprio conceito de iconicidade.

Assim, os critérios para estabelecer relações de similitude passam a ser relativos a cada contrato social, variando a depender da cultura. Além disso, quando se fala em níveis, está se tecendo uma comparação, confrontando dois ou mais elementos. Dessa forma, não está apenas se falando de uma iconicidade com uma carga arbitrária, mas também de uma iconicidade dicotômica.

Por outro lado, no pensamento peirceano, a iconicidade é vista primeiramente à luz da primeiridade, que é uma categoria monádica. "Sei que não existem ícones "puros” e que as

\footnotetext{
${ }^{14}$ BOUISSAC, Paul. Iconicity and pertinence. In: Iconicity - Essays on the Nature of Culture; Festschrift for Thomas A. Sebeok. Tübigen: Stauffenburg - Verlag, 1986, p. 193-213 apud SIBERSTEIN, 2013, p. 87.
} 
três categorias são indissociáveis, mas se o debate gira em torno da iconicidade, é porque por algum motivo este aspecto do signo está sendo ressaltado.” (SILBERSTEIN, 2013, p. 90).

Seguindo essa linha de raciocínio, a liberdade que se pensa ter para estabelecer relações entre representamen e objeto segundo a própria vontade é equivocada, isso porque a relação já está no signo. Nós a percebemos e a entendemos por processos que passam pelas três categorias. Tomando o pensamento de Peirce, entende-se que, no signo icônico, o representamen se refere ao objeto por conta da semelhança qualitativa que existe entre os dois. Assim, a capacidade de representar pressupõe uma similaridade que o próprio signo determina.

Segundo Peirce, (CP 2.247), um ícone é um signo que se refere ao objeto que denota apenas em virtude de caracteres próprios, caracteres que ele igualmente possui quer o objeto realmente exista ou não. Ou seja, o que torna representamen e objeto semelhantes são qualidades que ambos possuem, independente de um dos dois não existir, portanto, qualidades que estão presentes fora de uma construção de relação arbitrária.

No entanto, ao se falar de iconicidade, pressupõe-se um objeto e um representamen que a ele se refere. Voltando à pintura de Giampietrino, existe algo que compõe a pintura que a faz ser semelhante à virgem Maria. Algo de qualidade que está na pintura e na Maria que viveu na Galileia no final do século I a.C.

Entretanto, como não conhecemos a verdadeira Maria - se ela tiver mesmo existido , o que temos são as representações dela, que já estão forjadas por ideologia, já estão constituídas em memórias formadas por processos sociais e históricos. Nesse sentido, existe algo de qualitativo entre a Maria de uma pintura e a Maria de outra. Um caráter evidente é a brancura da pele, os traços finos do rosto, os cabelos castanhos claros. Essa seria a mãe da igreja católica, ou uma das referências de mãe mais presentes na memória dos brasileiros.

Pensando que tal pintura, ou representamen, em contato com seu objeto, cria uma imagem mental, que é seu interpretante; e que esse interpretante, por sua vez, é capaz de estabelecer também uma relação triádica com seu objeto, gerando um terceiro, seu interpretante, em um processo de semiose contínuo; pode-se perceber que existem outras qualidades possíveis de gerar relações de semelhança que não as assinaladas anteriormente.

Nesse sentido, ao pensar que a semelhança entre representamen e objeto no signo icônico já está no signo e que seu objeto é a qualidade da primeiridade, outras relações de caráter qualitativo são possíveis - portanto, reinterpretações do signo. "Como um primeiro 
não pode ser 'expressado simbolicamente, ele deve ser 'murmurado' poeticamente ou, antes, iconicamente" (DELEDALLE, 2000, p. 68 apud SILBERSTEIN, 2013, p. 94) ${ }^{15}$.

\begin{abstract}
Mesmo que o signo determine seu significado - que não é imutável, mas vivo e pulsante -, frequentemente não estamos prontos para interpretá-lo. É necessário um processo autocrítico e dedicado, além de uma boa dose de imaginação, para entender o que já está no signo. Além disso, o signo cresce, não se mantém estanque, então é sempre passível de reinterpretações. Criar é ouvir com cuidado e aguçar os olhos para a potencialidade do signo. Entender o que está no signo parte de imaginar, abdutivamente, possibilidades. (SILBERSTEIN, 2013, p. 95).
\end{abstract}

Esse "murmurar" da primeiridade permite, portanto, novos diálogos. Esse quadro de Giampietrino, em especial, traz um momento de muita intimidade entre mãe e filho - o instante de amamentar. Esse é um momento de bastante interação entre os dois, quando os corpos estão em contato e se conhece o ritmo do(a) filho(a). Santo Agostinho descreve essa cena ao tratar dos pecados da primeira infância:

Certa vez, vi e observei um menino invejoso. Ainda não falava, e já olhava pálido e com rosto amargurado para o irmãozinho caçula. Quem não terá testemunhado isso? Dizem que as mães e as amas tentam esconjurar este defeito com não sei que práticas. Mas se poderá considerar inocência o não suportar que se partilhe a fonte do leite, que emana copiosa e abundante, com quem está tão necessitado do mesmo socorro, e que sustenta a vida apenas com esse alimento? (AGOSTINHO, 2007, p. 5). ${ }^{16}$

A cena é tão completa que ou provoca admiração e louvação, ou ciúmes e agressividade. Portanto, outras relações possíveis de semelhança são, por exemplo, entre essa pintura de Giampietrino e as mães de carne e osso que vivem e amamentam seus filhoS pelo Brasil a fora. Essas são as mães que relatam o instante da amamentação em textos no facebook, em conversas corriqueiras, em vídeos que pedem pelo direito de amamentar em espaços públicos sem que sejam julgadas por isso. Essas são narrativas possíveis de memórias que se entrelaçam em um processo histórico. E os vários textos que passam a compor a memória de um povo são organizados a partir de valores sociais. Seguindo a história bíblica e

\footnotetext{
15 Essa é uma tradução livre da autora do original "as a First cannot be 'expressed' symbolically, it has to be 'mumbled' poetically or, rather, iconically” DELEDALLE, Gérard. Charles S. Peirce`s philosophy of signs: essays in comparative semiotics. Bloomington: Indiana University Press, 2000 in SILBERSTEIN

${ }^{16}$ A fala de Santo Agostinho é depois retomada por Lacan em Escritos, primeira edição, francesa, de 1966, ao abordar a agressividade em psicanálise. "Assim liga ele imperecivelmente, à etapa infans (anterior à fala) da primeira infância, a situação da absorção especular: a criança contemplava, reação emociona; inteiramente pálida, reativação das imagens da frustração primordial; e com uma expressão amarga, que são as coordenadas psíquicas e somáticas da agressividade original (LACAN, 1998, p. 117).
} 
as representações que se costuma fazer de Maria, ela não é como outra mãe de carne e osso comum, mas é possível que se façam analogias.

A importância de Maria como dinvindade, conforme sua história, aumenta por conta do nascimento de Jesus. A percepção de que quase todas as representações de Maria são de após esse fato é índice de que isto foi o que a enalteceu, que a tornou digna de ser santificada. Nesse sentido, Maria se transforma (ou se completa, a depender do ponto de vista) pelo nascimento do filho.

\subsubsection{A mãe e a esfera privada}

Interessante notar como a relação de pureza está vinculada, também, a certa noção de pudor. Essa ideia talvez seja responsável por fazer com que as imagens de Maria sejam quase sempre sem um contato tão íntimo e corporal com o menino Jesus, evitando-se imagens de carícia e de amamentação, que a fazem próxima à mãe comum.

Sobre a convivência entre santos e seres humanos comuns, Sloterdijk faz interessante análise das pinturas do italiano Giotto, abordando como o pintor traça hierarquias entre os seres humanos ditos vulgares e os santificados.

Giotto, como pintor, é mais um novelista que um narrador de lendas, sua história da salvação tem mais de periódico — de um periódico da terra sagrada - que de leitura monástica. Suas cenas não se desenvolvem ante as olhadas de teólogos mistéricos e eremitas, mas ante uma sociedade urbana e cortesã que à hora da eleição de seus temas de conversação apenas nota a diferença entre história sagrada y profana. A narração, como a sociedade moderna, se alimenta de curiosos. De modo que o que percebem os observadores da cena pictórica é também o que veem quem está ao redor nela. ${ }^{17}$ (SLOTERDIJK, 2015, p. 422).

Essa ideia de que seres humanos comuns poderiam convider com santos me fez pensar no que seria da ordem do privado e no que seria da esfera pública para as imagens de santos. Isto pensando nos ensinamentos que as histórias e representações deles trazem para as pessoas em geral. Nesse sentido, penso no que deveria ser escondido e no que poderia ser mostrado. Portanto, outro caminho de interpretação em referência aos carinhos e afetos que

\footnotetext{
${ }^{17}$ Tradução livre da autora, do original: Giotto, como pintor, es más bien un novelista que un narrador de leyendas, su historia de la salvación tiene más de periódico — de um periódico de la tierra sagrada — que de lectura monástica. Sus escenas no se desarrollan ante las miradas de teólogos mistéricos y eremitas, sino ante una sociedad urbana y cortesana que a la hora de la elección de sus temas de conversación apenas nota la diferencia entre historia sagrada y profana. La narración, como la sociedad moderna, se alimenta de curiosos. De modo que lo que perciben los observadores de la escena pictórica es también lo que ven quienes están alrededor en ella. (SLOTERDIJK, 2015, p. 422).
} 
não são mostrados é a ideia de que eles seriam da ordem do privado, algo que deveria ser escondido por não ser da esfera pública. Observe-se a seguinte figura de Maria.

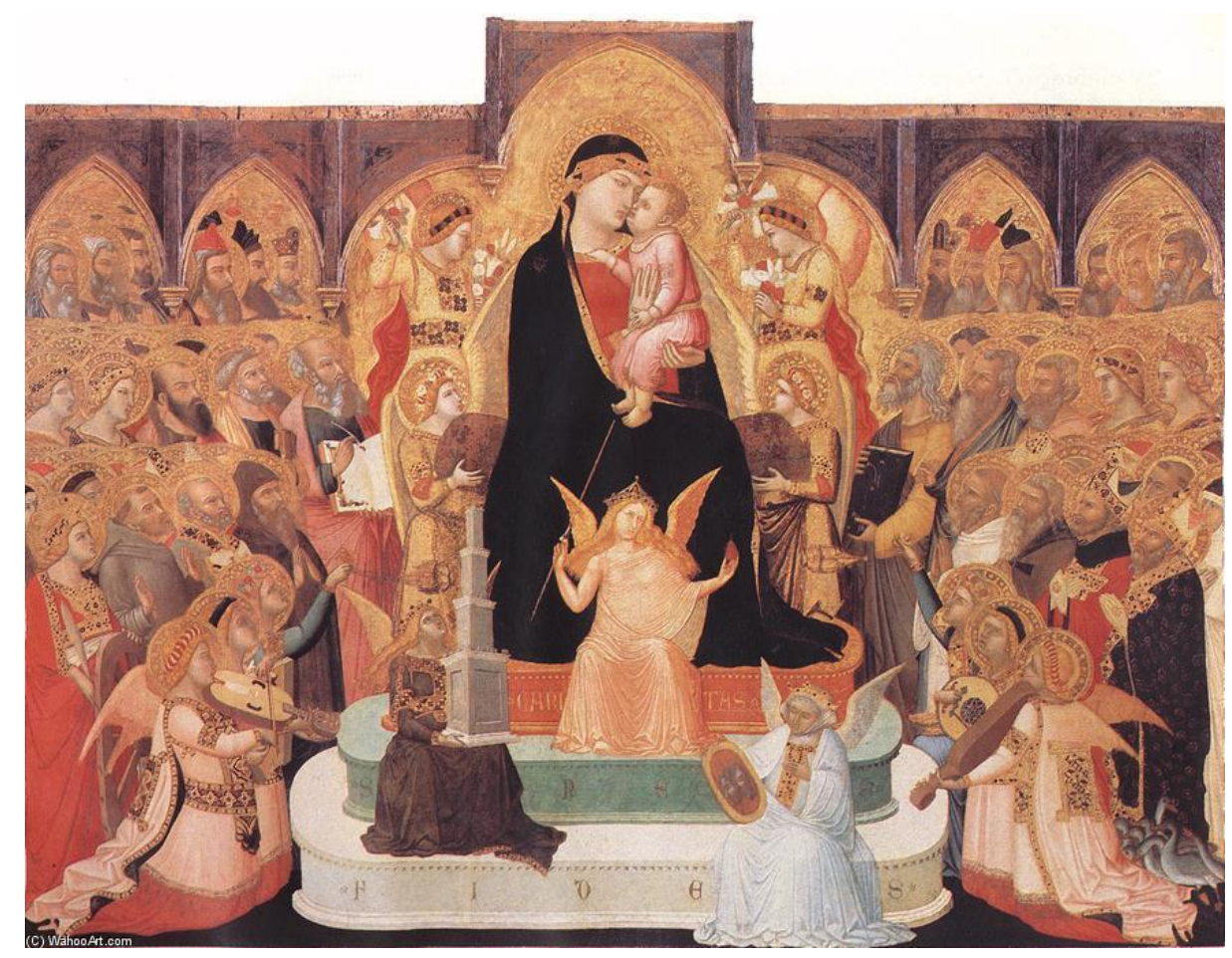

Fig. 2. Ambrogio Lorenzetti, Virgen con ángeles y saints, 1335, Itália.

A pintura acima é examinada por Sloterdijk (2015). Ambrogio Lorenzetti é um dos sucessores de Giotto que trabalhou o espaço intermediário entre as faces. Nessa cena, os dois personagens centrais voltam-se um para o outro e se beijam. Sobre o ato enunciado, o autor observa: "como si quisieran convertir al observador en un testigo que no pudiera captar de las intimidades de las personas más sagradas más que impresiones laterales, perfiles." (SLOTERDIJK, 2015, p. 438).

Isto é, o ato observado constitui-se como da ordem do privado, que acaba por se tornar público na cena, tendo como testemunhas não apenas o observador da pintura, mas também os outros personagens que ajudam a compor a tela. "Aquí, la imagen religiosa cultual, que por la postura frontal parece querer atraer al observador a su espacio de sentido, se convierte en una narración pictórica de un eros sagrado y privado a la vez." (SLOTERDIJK, 2015, p. 438).

$\mathrm{Na}$ cena, a figura pública do salvador da humanidade, por assim dizer, é convertida para dar espaço aos afetos de uma criança comum, como outra qualquer, que não consegue discernir, com base nos parâmetros sociais, o que seria da ordem do público e o que seria do privado. 
O menino Jesus já não é o Salvador de sempre que, sentado no colo da mãe, antecipa a história da Paixão [...] liberado um segundo de suas tarefas de representação, pode o infans Jesus desfazer-se em carícias com sua mãe; não há aqui um roteiro que arrebate a criança a contextos cósmicos; por um instante precário o Salvador oficial goza de un pequeno respiro na história da salvação. ${ }^{18}$ (SLOTERDIJK, 2015, p. 438).

Nesse sentido, torna-se interessante observar que existe no entendimento da maternidade uma contradição explícita: apesar da supervalorização dela para a mulher, como um papel social que desempenha; o papel de mãe é desvalorizado no âmbito da sociedade e relegado a algo da ordem do privado. Como decorrência disso, percebe-se que, quando a mulher ocupa um cargo de governo tão importante quanto a presidência da república, acaba longo sendo associada à figura materna. Exemplo disso foi a utilização da página do facebook intitulada "Dilma boladona" como recurso de campanha da presidenta à época Na página, Dilma sempre se remetia a si mesma como "mãe", "mamãe".

Nessa linha de pensamento, o estudo mais antigo e erudito sobre o matriarcado, que se deve ao jurista suíço Johann Jakob Bachofen, estabelece como feito moral e histórico a primazia do denominado "direito materno". Sua obra "Das Mutterrecht" foi publicada em Stuttgart em 1861.

Partindo de argumentos apoiados em sua maioria de fontes históricas tomadas da poesia - como Hesíodo, Pindaro, Ovidio e Virgilio - Bachofen acreditava que o "direito materno" nasceria da associação natural e biológica entre mãe e filho. O matriarcado ${ }^{19}$ ou domínio da mãe sobre a família e o Estado seria uma evolução posterior gerada pela insatisfação feminina ante a "sexualidade descontrolada" a que o homem a havia submetido. (BAMBERGER, 1979, p. 64). ${ }^{20}$

Trouxe essa inquietação da contradição porque ela é constituinte do self materno. Minha vontade inicial de pesquisa sobre o tema foi o fato de perceber mulheres que queriam muito tornar-se mães e, depois do nascimento do bebê, sentirem-se muito tristes. Mesmo que

\footnotetext{
${ }^{18}$ El Niño Jesús ya no es el Salvador de siempre que, sentado en el regazo de la madre, anticipa la historia de la Pasión [...] liberado un segundo de sus tareas de representación, puede el infans Jesús deshacerse en caricias con su madre; no hay aquí un guión que arrebate al lactante a contextos cósmicos; por un instante precario el Salvador oficial goza de un pequeño respiro en la historia de la salvación. (SLOTERDIJK, 2015, p. 438).

${ }^{19} \mathrm{O}$ matriarcado é um sistema de governo em que realmente governaram as mulheres. (BAMBERGER, 1979, p. 66).

20،“Así, a pesar de su pretendidos conceptos progresistas sobre el matriarcado arcaico, Bachofen ha continuado fomentando, mediante la fantasía y la ficción, un status quo que ha llegado a sernos demasiado familiar. Al sobrevivir al derecho materno em sus múltiples aspectos, la maternidad ha quedado subordinada a la firme vigilácia propetora del derecho paterno bajo el cual ha experimentado un florecimento. (BAMBERGER, 1979, p. $65)$.
} 
o imaginário da suficiência do desejo materno seja generalizado, existem também sentimentos de desvalorização social que permeiam a concepção que se tem da maternidade. "Entre la mítica omnipotencia de la madre primordial y la real subordinación social y sexual de las mujeres media um duelo difícil, que muchas no llegan a realizar.” (GABA, 2007, p. 211).

Quando insiro aqui a imagem de Maria, não quero dizer que todas as mães se identifiquem com sua figura, mas que ela constitui um elemento que significa dentro da cultura - e que, por conta do nosso processo de colonização, acaba sendo um dos elementos centrais de constituição do que vem a ser mãe no sentido de doação e pureza. Um elemento que está em constante relação com outros na vida social, nas representações. Uma figura que constitui relações triádicas e que articula conexões com outras nas reinvenções dos selves. Apesar de não ser uma pessoa comum, imagens que a revelam em momentos de mais intimidade com o menino Jesus a tornam mais próxima das outras mães do mundo, em concepções de pureza, completude e incompletude.

\subsubsection{Completude e incompletude e o caso das amas-de-leite}

Tive então um sentimento de que nunca ouvi falar. Por puro carinho, eu me senti a mãe de Deus, que era a Terra, o mundo. Por puro carinho mesmo, sem nenhuma prepotência ou glória, sem o menor senso de superioridade ou igualdade, eu era por carinho a mãe do que existe. Soube também que se tudo isso "fosse mesmo" o que eu sentia - e não possivelmente um equívoco de sentimento - que Deus sem nenhum orgulho e nenhuma pequenez se deixaria acarinhar, e sem nenhum compromisso comigo. Ser-lhe-ia aceitável a intimidade com que eu fazia carinho. O sentimento era novo para mim, mas muito certo, e não ocorrera antes apenas porque não tinha podido ser. Sei que se ama ao que é Deus. Com amor grave, amor solene, respeito, medo e reverência. Mas nunca tinham me falado de carinho maternal por Ele. E assim como meu carinho por um filho não o reduz, até o alarga, assim ser mãe do mundo era o meu amor apenas livre. (LISPECTOR, 1970).

Não foi por acaso que trouxe a figura de Maria para tentar entender algumas representações que são feitas sobre a ideia de ser mãe. A maternidade é um tema muitas vezes apresentado e compreendido como sagrado. Badinter (1985, p. 10) também relaciona a santidade nas obras que o abordam com a imagem de Maria, símbolo do indefectível amor oblativo. Mesmo para os que não são cristãos, esculturas e pinturas da santa são reconhecidas.

Essa relação, sendo óbvia ou não, me faz ao menos perceber o quanto é difícil questionar o amor materno - o amor que completaria a mulher -, pensando que quando ele não existe ou quando ele aparece imperfeito a mãe é mal jugada. Basta lembrar daquela cena clássica das novelas e filmes em que a mãe, após o parto, recebe o bebê em seu colo com todo 
o carinho e cuidado, já a demonstrar um amor sublime, que aparenta ser quase instintivo e certo - pensando em instinto como uma tendência inata e poderosa. Esse sentimento maternal teria de ser, portanto, partilhado por todas as mulheres. Se assim o fosse, toda mãe teria uma pulsão irresistível a se ocupar do filho.

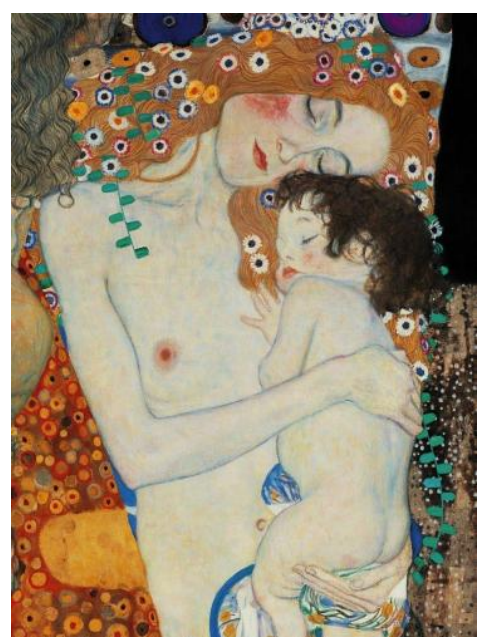

Fig. 3. Gustav Klimt, Mother and Child, 1905, Áustria.

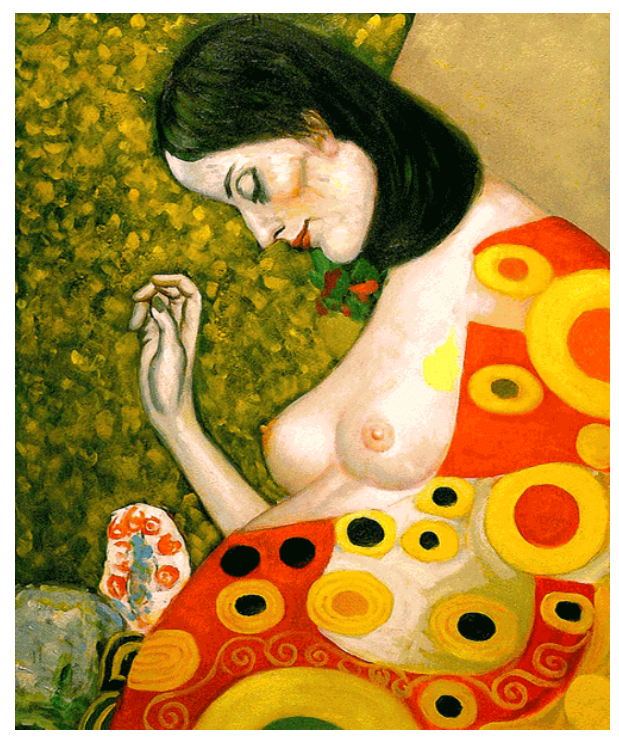

Fig. 4. Gustav Klimt, Hope II, 1907-1908, Áustria.

Gustav Klimt foi um dos pintores que retrataram mulheres e seus bebês. Em meio aos mosaicos de cores, sobressaem de suas obras os corpos femininos. As flores vêm como índice de carinho, afeto, aconchego, cuidado. O carinho com que a mãe segura o filho na Fig. 3, com os cabelos cobertos por flores e os olhos fechados, remete à ideia do amor incondicional da mãe para com o filho. É na relação dos dois, na união dos corpos que está a 
completude da cena. Essa noção é o que pode trazer a assimilação mulher = mãe. Da mesma forma ocorre na Fig. 4 em que a mãe, enquanto acaricia a barriga de gravidez, observa-a com atenção, como a sentir esse amor antes mesmo de conhecer a criança.

Trouxe essas figuras para tentar me aproximar do que as entrevistadas falam a respeito de completude-incompletude, mostrando a ideia de que necessitam de uma criança para lhes completar, para não se sentirem tão sós. Não quer dizer que o pintor tenha pensado nessa relação para fazer as pinturas, mas é possível que ela seja feita ao se tentar entender o que o signo significa - pensando na qualidade da primeiridade que eu falava.

As possíveis representações de maternidade que podemos encontrar na cultura são elementos que ajudam a constituir o self, junto a outras experiências vividas no dia-a-dia das mulheres. Essas representações vão sendo imbricadas na memória do self da mulher e, à medida que, por processos de inquirição, a mulher vai entendendo seu lugar de mãe e se estabilizando nele.

O reconhecimento desse lugar se dá para cada história específica e não para um dever ser no sentido de uma convenção (o que uma mãe deve ser?). A mulher, ao engravidar, gerar um(a) filho(a) e o(a) assumir passa por um processo de realocação como mãe na sua história. Portanto, processo histórico. Em um texto publicado em um perfil particular no facebook no dia 10 de junho de 2016, encontra-se o seguinte desabafo:

Não, esse não é (ainda) o relato do parto do nascimento de Lara... uma
intensa aventura que vivemos há 10 dias... esse é o relato do meu
(re)nascimento. Do parto da Fabíola mãe, que está só começando... com
dolorosas contrações ainda espaçadas, de intensidades variáveis, intercaladas
por momentos de certa anestesia e cobertas por um amor indescritível [...]
Me toquei que durante os últimos 9 meses li muito sobre como e quando
nascem os bebês, e muito superficialmente refleti sobre o nascimento da
mãe... agora, a cada minuto me redescubro nesse processo...

E esse reposicionamento no mundo se dá por processos de inquirição que levem ao entendimento de sua nova posição. Cada mãe, a sua maneira, vai criando mecanismos para se realocar no social em condutas de ação que provêm da compreensão que têm do conceito "mãe".

Essa realocação da mulher pelo que nomeia como "mãe", a partir de referências de representações da mãe, envolve diálogos culturais e sociais que estão para além de um desejo inconsciente ou uma vontade biológica. Ela é construída na organização de valores que formulam a separação de gêneros e de papeis sociais. Além disso, permeia uma relação tanto 
com o corpo quanto com os pensamentos, isto porque os dois não se dissociam, constinuindo o self. Nesse ínterim, ela não seria nem puramente natural nem exclusivamente cultural.

Também não se deixa apreender em termos da dicotomia público/privado: o filho nasce em uma relação intersubjetiva originada na intimidade corporal mas é, ou será, um membro da comunidade e, por isso, o vínculo com ele está regido também por relações contratuais e códigos simbólicos. A maternidade, então, é uma função construída como natural e necessária por uma ordem cultural e contingente. Se bem o corpo materno tem uma realidade biológica, no tem significação fora dos discursos sobre a maternidade $^{21}$. (GABA, 2007, p. 208).

Por mais que a reprodução seja um feito biológico que se localiza no corpo da mulher, trata-se da geração de um ser humano e, portanto, não pode ser puramente biológico. Dessa forma, pensando no que venho trabalhando argumentativamente neste texto, a construção da memória da maternidade como equivalente à reprodução da espécie e como único sentido da existência feminina constitui uma dupla falácia. Primeiro porque a categoria de mãe não esgota a de mulher; segundo porque a maternidade não inclui o processo completo da reprodução, visto que a fecundação da mulher requer do princípio masculino. (GABA, 2007, p. 206).

Deve-se, portanto, pensar a noção de mulher como sujeito e não como mero substrato corporal da reprodução ou executora de um mandato social ou encarnação de um ideal cultural. Por isso, a importância de trazer experiências e memórias de mães que, embora constituídas no social, carregam algo de singular. São selves em comunhão pelo ato de comunicar, que desenvolvem hábitos comuns. Mas cada uma, por suas particularidades, pode gerar sentidos que transformam o todo semiótico que constitui a memória social: cada uma é construtora de sua história. São seres em ação carregados de potência de criação.

Retomando o que falava sobre ícone, enfatizo a primeiridade como capaz de quebrar relações de hábitos e gerar novos. Conforme esse caráter pode-se perceber determinada semelhança entre as mães devida a alguma qualidade comum que possuam e, também, enxergar novas semelhanças, decorrentes de outras qualidades. O conceito de ícone expandese a outros signos, que não somente aqueles que se costumam associar a ele - desenho,

21 Tradução livre da autora, do original: "Tampoco se deja aprehender en términos de la dicotomia público/privado: el hijo nace en una relación intersubjetiva originada en la intimidad corporal pero es, o ha de ser, un membro de la comunidad y, por ello, el vínculo com él está regido también por relaciones contractuales y códigos simbólicos. La maternidad, entonces, es una función construida como natural y necesaria por un orden cultural y contingente. Si bien el cuerpo materno tiene uma realidade biológica, no tiene significación fuera de los discursos sobre la maternidad." (GABA, 2007, p. 208). 
pintura, foto - e pode ser dialogado com os selves, pensando nas semelhanças qualitativas que possam ter entre si.

Olhando para a completude que um filho supostamente traria à mulher, o sentimento do amor materno entra dentro dessa concepção da maternidade como algo biológico e transforma-se em algo natural e intrínseco à mulher, e não como potência a ser construída na relação entre mãe e filho(a). Por isso um sentimento tão difícil de ser posto em questão. Em decorrência dessa concepção - construida historicamente - ao se falar em abandono de crianças por parte da mãe, a sociedade em geral fica muito horrorizada.

Por conta de existirem casos de abandono, de mulheres que não querem ter filhos, de mães que não amam tanto assim suas crianças, de mães que optam politicamente por enxergar a relação com os filhos de maneira diferente dos hábitos vigentes; enfim, por conta de diferenças que existem e dão a ideia de certo isolamento em meio aos hábitos; também por conta da comunicação entre os selves que faz gerar hábitos de ação; considero interessante trazer como categoria de análise isolamento-comunhão. As noções de completudeincompletude e de pureza advêm da comunhão entre os selves.

Sobre o amor materno, a questão colocada por Badinter $(1985$, p.8) é se ele é um instinto, uma tendência feminina inata ou se depende, em grande parte, de um comportamento social variável de acordo com a época e os costumes. Se depender desses últimos, depende também das representações que se faz dele nas obras, filmes, novelas, romances, contos. Para a autora o instinto materno é um mito, não havendo uma conduta materna universal e necessária. Ela constata a extrema variabilidade desse sentimento, segundo a cultura, as ambições ou as frustrações da mãe. Como outros sentimentos humanos, esse amor é incerto, frágil e imperfeito. Pode inclusive existir ou não, aparecer e desaparecer, mostrar-se forte ou frágil; a mulher pode preferir um filho ou ser de todos. A autora contraria a crença generalizada de que ele está profundamente inscrito na natureza feminina - bem ao encontro da primeira categoria, que é potência de ser.

Badinter (1985) traça um panorama histórico, focado principalmente em países ocidentais, em que verifica que o interesse e a dedicação à criança não existiram em todas as épocas e em todos os meios sociais. As diferentes maneiras de expressar o amor vão do mais ao menos, passando pelo nada, ou quase nada, pois não é um sentimento inerente à condição das mulheres, mas algo que se adquire. Tal como o percebemos hoje, é resultado de processos sociais e culturais.

Importante notar que quaisquer observações históricas devem ser olhadas com cautela. O que se tem são dados e documentos, mas sabe-se que é reconhecida a 
impossibilidade de um observador, por mais circunspecto e cauteloso que seja, despojar-se de seus valores e de suas paixões.

Essa observação é feita pela própria autora: "uma vez que uns e outros dispõem das mesmas informações, como explicar a divergência das interpretações, senão pelas divergências de nossas filosofias, ideologias ou paixões respectivas?” (BANDITER, 1985, p. 8). Ela cita como exemplo a permanência da criança na casa da ama-de-leite no século XVIII. Não há quem conteste os números mencionados, nem a amplitude do fenômeno nas cidades de média ou grande importância, apesar disso, os historiadores chegam a ideias opostas. Nos séculos XVII e XVIII, as crianças eram normalmente entregues, desde tenra idade, às amas, para que as criassem, e só voltavam ao lar depois dos cinco anos:

Há quem pense que as mães urbanas que enviaram seus bebês para o campo deram com isso uma prova cabal de seu amor materno. Convencidas das vantagens do ar do campo e da nocividade da urbe, elas teriam sacrificado o seu desejo de maternagem à saúde da criança. Assim interpretada, a entrega do filho a uma ama-de-leite para ser criado deixa de ser sinal de desinteresse pela criança afastada, tornando-se ao contrário, a ilustração suprema do mais puro altruísmo. O amor materno está salvo. [...] Minha interpretação como a de alguns outros - não revela o mesmo otimismo. Se podemos admitir que a entrega da criança a uma ama-de-leite tenha sido, para algumas mães, uma prova de amor ao filho, podemos legitimamente duvidar de que o mesmo tenha ocorrido em todos os casos. O fato de todas as classes da sociedade urbana - mesmo nas pequenas cidades, menos "empesteadas" que as grandes - terem utilizado os serviços de amas mercenárias e aceitado longas separações dos seus bebês parece-me que deve ser interpretado de outra maneira. (BANDITER, 1985, p. 8).

A despeito de qualquer viés de interpretação, uma coisa é certa: cada mulher que se torna mãe tem uma experiência pessoal da maternidade. Os casos das entregas dos filhos às amas, por exemplo, são decorrentes de circunstâncias e motivos singulares. O fato é que muitas crianças morriam e as mães, mesmo assim, continuavam enviando seus filhos para as mesmas amas. Trago esse exemplo dos casos das amas porque ele permite entrever um ideal de amor e de categorização das mães que concorda com essa ideia da perfeição, doação e da completude.

O intuito de trazer esses dados, portanto, não é culpar essas mães; ou, por outro lado, inocentá-las; e, para além disso, eliminar o papel do pai na tomada de decisão e na responsabilidade sobre os filhos. Meu intuito é perceber como essas contradições das mães aparecem nos processos que se formam em suas memórias enquanto hábitos (memórias que se alimentam de sentimentos e são alimento deles), entendendo a possibilidade de uma mulher 
ter sentimentos contraditórios - e até mesmo ruins - pelo filho na constituição do complexo que é o signo self.

Interesse ou desinteresse pelas crianças por parte de suas mães, o fato é que as interpretações de um mesmo ato - no caso das amas, visto como abandono, doação, ou preocupação das mães - percorrem o tempo, constituem memórias e esquecimentos na história. Os hábitos permeados por ideologias e relações de poder fazem esquecer interpretações contrárias a eles. No caso das amas, não se pode perder de vista, por exemplo, que até fins do século XVIII a taxa de mortalidade infantil era muito alta, o que permite a interpretação também de que, se a mãe se apegasse intensamente a cada um de seus bebês sem dúvida morreria de dor. Esse desinteresse pela criança que acabara de nascer poderia servir, portanto, de couraça sentimental. (BANDITER, 1985, p. 10).

As análises em um momento e situação apresentados somente são possíveis em decorrência de interpretações sucessivas atribuídas aos objetos no percurso da história, no transpassar do tempo. As concepções de pessoas de diferentes gerações sobre um mesmo objeto são memórias que persistem na cultura de épocas posteriores.

São essas memórias que permitem que determinadas interpretações na contemporaneidade sejam viáveis. Isto levando em consideração que toda e qualquer análise envolve discursos e relações de poder. Eu, no meu local de fala, examino os relatos das entrevistadas me baseando no discurso acadêmico, trazendo como referencial teórico a semiótica - principalmente os estudos de Peirce - e me remetendo a alguns textos do feminismo pós-colonial. O discurso da capoeira, por vezes encontrado no meu texto, entra como diálogo possível, referência simbólica e experimentação quase literária.

Ao trazer as contradições que existem entre a supervalorização do papel de mãe na vida da mulher e a desvalorização desse lugar na vida pública; além disso, ao trazer, também, as contradições dentro das formulações do sentimento do amor materno e a possibilidade de não se querer ter filhos, tento abarcar um pouco do complexo que envolve a afirmação explícita ainda na cultura brasileira - mas que aos poucos vem se transformando - de que mulher e mãe estão intrinsecamente imbricadas.

Nesse sentido, procuro por outras dimensões que a maternidade possa ganhar, para além da completude e pureza. Que ela possa adquirir outros significados ao se problematizar os hábitos que a constituem. Isto sabendo que sua concepção se dá em diálogos entre o amor, a moral, os valores sociais, os religiosos, o desejo da mãe, o da mulher. Esses são diálogos narrados nas imagens das mães. As figuras revelam ainda o que não está contido nelas, mas está nas entrelinhas, que se refere à relação entre os dois sexos - feminino e masculino e as 
relações de poder que existem entre eles. No próximo capítulo, tratarei dessa relação e dos conceitos de self e sinequismo. 


\section{Capítulo 2}

Pensando o self mãe

Dendê, ô, dendê Dendê de aro amarelo Dendê de aro amarelo Vou dizer a dendê

Eu sou homem E eu sou mulher. Vou dizer a dendê

Eu sou homem E eu sou mulher.

(Corrido de Capoeira Angola).

\subsection{Nomeação e ação em trabalho e jogo}

Falar de maternidade por um momento me assustou. A mãe, grande parte das vezes, acaba constituindo uma ligação muito forte com o filho. Eu saí de casa há pouco tempo e foi mais difícil do que poderia ser por conta da relação que tenho com minha mãe. Muitas das minhas lembranças a têm. Muitas das suas têm ao menos uma de suas três filhas.

Nesta dissertação, como disse anteriormente, entrevisto ao todo quinze mães e cinco mulheres que não entraram na trajetória da maternidade e, talvez, nunca cheguem a entrar, por opção ou por circunstâncias da vida. Além disso, enuncio aqui conversas sobre maternidade de que participei no meu dia-a-dia, ainda que apenas como ouvinte em algumas delas. Procurei diversificar as entrevistadas: grávidas, mães de filhos recém-nascidos, de bebês, de crianças, de adultos. São mulheres, algumas conhecidas minhas, outras, não. De classes sociais, idades, cores, naturalidades diferentes. Todas, porém, brasileiras, residentes no Brasil.

É possível identificar, já de cara, hábitos de formulação comuns ao conceito de mãe. Uma associação preponderante nas falas das entrevistadas às palavras: entrega, dedicação, doação, responsabilidade. As mães de crianças falam bastante também em paciência.

No meu grupo de capoeira angola, ao observar as futuras mamães, percebo que o crescimento da barriga não as impede de entrar na roda. Jogam até bem perto do momento de nascimento da criança - e depois passam a levá-las consigo. Acho interessante essa observação porque desmistifica a ideia de que a gravidez impede que a mãe continue a 
executar suas atividades até bem próximo do dia do parto. Na capoeira, a observação do jogo de uma mulher grávida com um homem torna explícita a demarcação dos gêneros.

Abordarei neste capítulo a divisão binária que se faz entre sexos e gêneros, tratando da desconstrução da naturalização dessa ideia a partir da perspectiva construtivista de estudos de historiadoras e historiadores feministas da história cultural. Essa abordagem é importante porque a maternidade é naturalmente atrelada à mulher, o que implica uma separação entre dois gêneros e traz à tona muitos discursos reproduzidos em nossa cultura, trazendo ainda a premissa de que a função social da mulher é a procriação, como falava no primeiro capítulo desta dissertação.

Com isso em mente, gostaria de retomar a máxima pragmaticista já enunciada: "considere quais os efeitos que possivelmente podem ter a influência prática que você concebe que o objeto de sua concepção tem. Neste caso, sua concepção desses efeitos é o TODO de sua concepção do objeto" (PEIRCE, 2010, p. 291). A concepção que se tem sobre o conceito de mãe influencia efeitos práticos. Assim a concepção de tais efeitos é o TODO da concepção do conceito. As ações, a forma como agimos eticamente no mundo a partir da nomeação que damos à mãe são os efeitos práticos que concebemos. E esssa nomeação se dá pelos valores culturais. Por isso, no primeiro capítulo trouxe algumas referências que ajudam a compreender certos hábitos advindos da nomeação de mãe.

Nas entrevistas, busco pelos processos de inquirição das mães como selves que tentam entender-se e posicionar-se enquanto mulheres e mães em suas atividades humanas. São inquirições feitas a partir da nomeação e, também, para nomear. Nesse sentido, interpreto as falas dessas mulheres com o entendimento de que existe o ato de filosofar nessa nomeação e ação.

A filosofia é uma ação humana inevitável, seja ela boa ou má. (d'ORS, 1998, p.43). Filosofar e viver a um só tempo, a consciência é a razão da dignidade. No programa filosófico de d'Ors, o ser humano completo trabalha e joga. Ele trabalha quando vence as resistências, considerando a ação humana como interventora no mundo. E, para além das necessidades práticas, o ser humano joga, isto é, contempla interessado o espetáculo de sua luta, pensa só por pensar, e até inventa resistências novas com o exclusivo objetivo de vencê-las. Ou seja, não é mero contemplador, nem simples ator. Ação e contemplação são dois aspectos da mesma realidade íntima, o sentido do homem, sua inteligência.

Trabalho e jogo, no entanto, não devem ser vistos em um dualismo estrito, em que um está completamente separado do outro. Pelo contrário, esses conceitos se encontram em um dinamismo que é o próprio curso da vida. Quando a mulher se encontra com a realidade 
de ser mãe, esses processos cíclicos entre trabalho e jogo desenrolam-se para que ela possa se reconfigurar em um novo estar no mundo.

Após Fátima, 36, contar que virou outra pessoa depois de ter filho, eu lhe disse que gostaria que ela falasse um pouco sobre o que a ajudou a se posicionar de outra forma, agora como mãe, se havia sido o desejo muito grande de ter filhos, mencionado anteriormente na entrevista.

É, na verdade, assim, o processo é brutal, porque quando você está grávida, pelo menos essa foi a minha experiência pessoal, apesar de ter tido uma gravidez de risco, de ter passado por algumas coisas, foi um momento muito emocionante para mim. Todo esse lado emocional que se apurou, eu ficava muito satisfeita de estar grávida, feliz, me sentindo feliz e realizada, completa e, quando a criança nasce, vem uma realidade assim chocante, nossa, agora é definitivo! Agora é para sempre! Sabe o bebê não tem como você devolver a criança [...] Então, é bem brutal assim, essa constatação, é... é aquele momento que, minha mãe que falava isso assim, é... vai chegar o momento em que vai cair a ficha pra você, o que é ser mãe, e na hora que cair você vai ver o peso da responsabilidade e, realmente tudo isso te transforma numa outra pessoa. Eu acredito que sim, como era algo que eu queria muito vivenciar, então isso me ajudou a passar pelo processo de uma forma, talvez, mais tranquila.

As transformações no self mãe acontecem, portanto, dentro da lógica dos movimentos de jogo e trabalho. O primeiro trata da imaginação e da contemplação do sentir, que exibem a parte estética da experiência: "foi um momento muito emocionante para mim", "eu ficava muito satisfeita de estar grávida, feliz, me sentindo feliz e realizada, completa". O trabalho refere-se às resitências e ações que se interpõem à realidade: "quando a criança nasce, vem uma realidade assim chocante, nossa, agora é definitivo! Agora é para sempre! Sabe o bebê não tem como você devolver a criança". Pensando na entrevista, a constatação da realidade que seria "para sempre" é uma resistência que pede uma ação como resposta, um trabalho. O movimento de trabalho e jogo é cíclico no ato de filosofar como pressuposto para a vida.

\subsection{Gênero e sexo: a criação do self mãe}

Na nomeação do que vem a ser mãe encontra-se a divisão dual entre gêneros, que passa por relações de poder e ideologias construtoras dos hábitos. Essa divisão é fundamental na concepção das mulheres enquanto indivíduos autônomos, até porque ela é naturalizada em nossa sociedade. Abordar esse tema é importante porque o entendimento do conceito de mãe 
pesssupõe representações em que a mulher e o homem são separados e hierarquicamente relacionados. E a mulher acaba adquirindo importância à medida que cumpre o papel de reprodutora.

Tal papel é expressão do social, por isso, ao pensar nas memórias compartilhadas pelas mães, é importante assimilar essas relações com o conceito de sinequismo. O self individual, como presença reagindo separado de outros selves e do seu futuro (ambos, seu futuro individual e seu futuro coletivo), possui um status meramente negativo. "Ser um self é estar em processo de tornar-se um self, um processo que nunca está completo.” (CP 6.157 apud COLAPIETRO, 2014, p. 124). Para desenvolver suas capacidades plenas de semiose enquanto signo deve ser entendido não apenas a partir de sua conexão com o futuro e com o passado, mas também de sua associação com outros.

Segundo Colapietro (204, p. 105), as visões de Peirce com relação ao self não têm sido adequadamente apreciadas porque não são estudadas de modo cronológico. Ela o faz a fim de esboçar o desenvolvimento dessas visões e exibir sua sutileza e força. A pesquisadora inicia lembrando algumas das mais importantes caracterizações negativas do self oferecidas por Peirce. Elas são, quando lidas sem consideração ao desenvolvimento do pensamento do filósofo, a fonte de muitos equívocos e críticas desorientadas. A seguinte citação de Peirce (5.317 [1969]; cf. 5.255-37 apud COLAPIETRO, 2014, p. 106) traz um pouco delas: "O homem individual, visto que sua existência individual é manifesta apenas por ignorância e erro, desde que ele é algo separado de seus colegas, e do que ele e eles devem ser, é apenas uma negação".

Nas questões 31 e 32 do manuscrito MS 1099, Peirce tece uma série de comentários sobre o volume I de Os Princípios da Psicologia, (The Principles of Psycology) de Willian James. Nessas explanações, são ressaltadas diferenças muito importantes entre os dois. $\mathrm{Na}$ questão 31, Peirce começa citando James: "Nenhum evento do pensamento vem na visão direta de um pensamento em outra consciência pessoal que não a sua. Isolamento absoluto, pluralismo irredutível é a lei."

Percebe-se que James sugere que mentes pessoais são absolutamente isoladas umas das outras. (COLAPIETRO, 2014, p. 107). Para ele, o self finito é caracterizado por uma ampla privacidade e está encerrado em seu próprio interior de tal maneira que se torna invisível a outros. Para Peirce (MS 1099 apud COLAPIETRO, 2014, p. 100), por outro lado, embora haja uma dimensão privada da consciência humana, ela não possui o alcance que tem para James. Este considera que os pensamentos pertencem a cada pessoa como propriedade, não existindo contemporaneidade, proximidade espacial ou similaridade de conteúdo capazes 
de fundir tais pensamentos; circundados que estão pela barreira de pertencimento a diferentes mentes pessoais.

No contexto do sinequismo, Peirce vai contra essa concepção do self individual isolado, o sinequismo tende a considerar todas as coisas como contínuas. Esse reconhecimento de continuidade, ou terceiridade, entretanto, não impõe a rejeição da disjunção ou secundidade. Essa doutrina da continuidade impede a visão do mental e do físico como irredutivelmente diferentes um do outro e, além disso, a vida de qualquer self é inseparável das vidas de outros selves. (COLAPIETRO, 2014, p. 109)

Peirce retratou o homem individual como uma negação única; o self pessoal principalmente como um fenômeno ilusório; identidade pessoal como uma concepção bárbara; existência pessoal como não somente um fenômeno ilusório, mas também uma brincadeira; e a pessoa individual como uma simples célula do organismo social. (COLAPIETRO, 2014, p. 110).

Ser um self é ser um possível membro de alguma comunidade (PEIRCE, 5.402 n.2 apud COLAPIETRO, 2014, p. 115); ou seja, é sempre, a princípio, possível para o self tornarse um a partir da relação com o outro. Entretanto, essa concepção não nos pode deixar esquecer que esse signo é também verdadeiramente algo em si mesmo à parte de suas comunicações com outros. Ou seja, cada mãe e cada mulher como indivíduos são constituídas por memórias que lhes permitem se identificarem como mentes dotadas das capacidades de autoconsciência, autocrítica e autocontrole.

\subsubsection{As formações de sentido no self na constituição de corpos sexuados}

Os movimentos de reciprocidade entre o social e o sujeito são assinalados por Teresa de Lauretis, em 1984, que já atrelava à materialidade o processo de subjetivação do feminino; ou seja, a composição do "ser mulher", numa operação de interação entre sentido, percepção e experiência. ${ }^{22} \mathrm{~A}$ natureza dessa experiência subjetiva/social/plural do feminino, segundo de Lauretis, estaria identificada na sexualidade, como um tipo particular de relação do feminino com a realidade social. A experiência é definida como um complexo de hábitos, disposições, associações e percepções que vão conformando um indivíduo enquanto fêmea (idem.). Ela considera que esse é o campo precípuo a ser analisado, compreendido e articulado pela teoria

${ }^{22}$ DE LAURETIS, Teresa. Alice Doesn't, Feminism, Semiotics, Cinema, Bloomington: Indiana University Press, 1984, p. 182 apud NAVARRO-SWAIN, 2002. 
feminista. O corpo seria o lugar em torno do qual os efeitos significantes do signo se corporificam (idem.) - e o corpo não se dissocia da mente, conforme o sinequismo.

A produção de sentidos sociais se condensaria, portanto, na instituição de corpos sexuados e na composição de sujeitos definidos por uma biologia estabelecida como marco decisório para sua inserção no social. “Ou seja, em torno do corpo, da experiência do corpo sexuado e sexualizado, forjado em práticas discursivas específicas, produz-se o feminino, o 'ser mulher'” (NAVARRO-SWAIN, 2002).

Nesse sentido, o "ser mulher" ou a "verdadeira mulher" é formado por representações do corpo sedutor, de um destino ligado ao corpo materno. Os diversos discursos vão fazendo parte da autorrepresentação da subjetivação identitária em mecanismos que regulamentam normas, modelos e valores.

Nesse ínterim, representação estaria na esteira da noção de Representação Social formulada por Denise Jodelet, vista como forma de conhecimento socialmente elaborada e partilhada, que tem um objetivo prático e contribui à construção de uma realidade comum a um conjunto social. As representações apoiam-se em valores variáveis segundo os grupos sociais dos quais adquirem suas significações. ${ }^{23}$ Estão ligadas a sistemas de pensamento traçados por discursos ideológicos constituídos nas dinâmicas de formação social. Formam-se na esfera social e na esfera de experiência privada e afetiva dos indivíduos. Representação social, por fim, são imagens, valores, normas, significações materiais e simbólicas que forjam o real.

A existência de representações hegemônicas não significa uma prisão sem saídas. Representações periféricas, em constante circulação, são parte de uma realidade não homogênea e garantem o dinamismo do social. O próprio feminismo forma grupos de representações periféricas, ponta de lança de profundas transformações sociais. A pergunta que Navarro-swain (2002) faz é: como repensar o mundo além do binário sexual e sexuado, uma vez que estamos nele inseridos, enquanto gênero demarcado pelo biológico?

Para ela, a constatação da desigualdade entre gêneros e sexos não elimina os mecanismos reguladores da assimetria e da hierarquia, fundados nas definições de sexo biológico e de práticas sexuais normatizadas. O feminismo como operador analítico de diagnóstico da construção sexuada dos seres esgota-se, porém, rapidamente em seu aspecto transformador ao não dar a devida problematização ao binarismo sexo/gênero.

\footnotetext{
23 JODELET, Denise. Représentations sociales : un domaine en expansion. In: Denise Jodelet (dir.) Les représentationssociales, Paris, Puf, 1989. p.31-61 apud NAVARRO-SWAIN, 2002.
} 
Gênero não está para a cultura assim como o sexo para a natureza, pois o gênero é também o significado cultural/ discursivo pelo qual a natureza sexuada ou o sexo natural é produzido e estabelecido como anterior à cultura, uma superfície neutra politicamente, na qual a cultura age." ${ }^{24}$

Nesse sentido, o corpo feminino, e também o masculino, não seriam opostos à cultura, mas seriam eles mesmos conformados por ela. Assim, é na instituição de um corpo sexuado feminino, enquanto evidência, que se apoiam os sentidos atrelados ao gênero, traduzidos em funções sexuadas e heterossexualidade compulsória. Do sexo biológico decorre o destino feminino e sua própria definição: maternidade, família e casamento, domínio do privado, sensibilidade, fragilidade, intuição, atributos da "verdadeira" mulher. Essa concepção vai ao encontro do que eu dizia no primeiro capítulo desta dissertação sobre a constatação na cultura do atrelamento biológico, natural e certo da mulher ao materno, transformando o fato em motivo de completude, de significado à vida.

Butler (2001) argumenta no sentido de que, aceitando a ideia de que a sexualidade é algo que todos nós, mulheres e homens, possuímos "naturalmente", fica sem sentido a analise a respeito de sua dimensão social e política ou de seu caráter construído. A sexualidade, para ela, não seria algo "dado" pela natureza, inerente ao ser humano. Tal concepção usualmente se ancora no corpo e na suposição de que todos vivemos nossos corpos, universalmente, da mesma forma. No entanto, a seu modo de ver, a sexualidade envolve rituais, linguagens, fantasias, representações, símbolos, convenções: processos profundamente culturais e plurais. Nessa perspectiva, nada há de exclusivamente "natural" nesse terreno, a começar pela própria concepção de corpo, ou mesmo de natureza.

É através de processos culturais que se define o que é, ou não, natural. Produzimos e transformamos a natureza e a biologia e, consequentemente, as tornamos históricas. Os corpos ganham sentido socialmente. A inscrição dos gêneros — feminino ou masculino — nos corpos é elaborada, portanto, no contexto de uma determinada cultura e possui suas marcas. As possibilidades da sexualidade — das formas de expressar os desejos e prazeres — também são sempre socialmente estabelecidas e codificadas. As identidades de gênero e sexuais são, portanto, compostas e definidas por relações sociais, elas são moldadas pelas redes de poder de uma sociedade. A sexualidade é uma invenção social uma vez que se constitui historicamente a partir de múltiplos discursos sobre o sexo: discursos que regulam, normatizam, instauram saberes e reproduzem valores e "verdades".

\footnotetext{
${ }^{24}$ BUTLER, Judith. Gender Trouble. Feminism and the Subversion of Identity, New York: Routledge, 1990, p. 7 apud NAVARRO-SWAIN, 2002.
} 
Aceita-se a transitoriedade ou a contingência de identidades de classe. A situação torna-se mais complicada, no entanto, se um processo semelhante ocorre com relação às identidades de gênero e sexuais. Uma notícia de jornal pode servir de exemplo: numa pequena cidade da Alemanha, o prefeito, algum tempo depois de eleito, assume publicamente uma nova identidade de gênero. Ele agora apresenta-se como mulher e comunica sua intenção de completar essa transformação através de processos médicos, especialmente cirúrgicos. A cidade inicia um movimento para destitui-lo pois, na opinião de grande parte da população, ele é agora "outra" pessoa. (BUTLER, 2001, p.7).

Em nossa cultura, a admissão de uma nova identidade sexual ou de uma nova identidade de gênero é considerada uma alteração essencial, uma alteração que atinge a "essência" do sujeito. Pela centralidade que a sexualidade adquiriu nas modernas sociedades ocidentais, torna-se difícil entendê-la como tendo as propriedades de fluidez e inconstância. Freqüentemente nos apresentamos (ou nos representamos) por meio de nossa identidade de gênero e de nossa identidade sexual. Essa parece ser, usualmente, a referência mais "segura" sobre os indivíduos. (BUTLER, 2001, p. 8).

Nesse sentido, pode-se reconhecer que os desejos e interesses do self e seus múltiplos pertencimentos sociais possam levá-lo a possibilidade de vários caminhos. No entanto, a incerteza, o desconhecido, a ameaça de dissolução, que implicam não ter uma identidade fixa fazem com que se tente fixar uma identidade. Nessa busca, afirma-se que aquilo que se é agora é o que, na verdade, sempre se foi. As pessoas necessitam de algo que dê um fundamento para suas ações e, então, constroem "narrativas pessoais", biografias de uma forma que lhes garanta coerência. Para Weeks, é isso que determina que o corpo seja a referência central. ${ }^{25}$

O "sexo" é um ideal regulatório cuja materialização é imposta: esta materialização ocorre (ou deixa de ocorrer) através de certas práticas altamente reguladas. Em outras palavras, o "sexo" é um constructo ideal que é forçosamente materializado através do tempo. Ele não é um simples fato ou a condição estática de um corpo, mas um processo pelo qual as normas regulatórias materializam o "sexo" e produzem essa materialização através de uma reiteração forçada destas normas. $O$ fato de que essa reiteração seja necessária é um sinal de que a materialização não é nunca totalmente completa, que os corpos não se conformam, nunca, completamente, às normas pelas quais sua materialização é imposta. (BUTLER, 2001, p. 111).

${ }^{25}$ WEEKS, Jeffrey. Invented moralities: sexual values in an age of uncertainty. Nova York: Columbia University Press, 1995, p. 89 apud BUTLER, 2001. 
Nesse ínterim, o gênero não pode ser visto como um constructo cultural que é simplesmente imposto sobre a superfície da matéria - quer se entenda essa como o "corpo", quer como um suposto sexo. Uma vez que o próprio "sexo" é compreendido em sua normatividade, a materialidade do corpo não pode ser pensada separadamente da materialização daquela norma regulatória. O "sexo" não é simplesmente aquilo que alguém tem ou uma descrição estática daquilo que alguém é, ele é uma das normas pelas quais o "alguém" simplesmente se torna viável, é aquilo que qualifica um corpo para a vida no interior do domínio da inteligibilidade cultural. (idem.).

Como um elemento constitutivo das relações sociais, o gênero, conforme Joan Scott (1995, p. 95), implica alguns elementos inter-relacionados: os símbolos culturalmente disponíveis que evocam representações simbólicas (com frequência contraditórias) constituem um deles - Eva e Maria como símbolos da mulher, por exemplo, na tradição cristã ocidental. O sexo visto como condição estática é materializado por normas e impõe ao gênero condições naturalizadas.

\subsubsection{O Conceito de self: identidades possíveis}

Pensando no sexo e no gênero como constructos das relações sociais, quero tratar de forma mais detalhada do conceito de self para ir compondo esta discussão a partir da questãoproblema: como o self mãe cria forma?

Para Mead (1962), a comunicação precede a emergência da mente, e essa se estrutura pela linguagem. Somos um self quando desenvolvemos a mente dentro do contexto da experiência social. A mente, portanto, implica a relação do organismo com uma situação histórico-social concreta, relação mediada por um conjunto de símbolos.

Por isso, a existência da mente somente é possível a partir da experiência dos gestos como símbolos significantes. A internalização dos significados dos gestos possibilita o diálogo do indivíduo consigo mesmo e abre a possibilidade de uma relação de entendimento com os outros. (CASAGRANDE, 2014, p. 15).

Mead (1962) entende que o self somente pode ser reconhecido na ação e na interação no decorrer da vida. O self - autocompreensão reflexiva de si mesmo - é constituído sob a lógica dos processos de socialização, numa matriz intersubjetiva e simbólica. Assim, para Mead, a individuação só é possível por conta da socialização, visto que a formação do self 
ocorre por meio da inserção do indivíduo nos processos de comunicação e consequente internalização das estruturas simbólicas presentes na linguagem. "O mecanismo empregado nesse processo é o da internalização da atitude do outro.” (CASAGRANDE, 2014, p. 7).

Compreendo, a partir daí, que muitas das referências de representação social da mãe são comuns entre as mães entrevistadas, fazendo elas parte de uma mesma semiosfera ${ }^{26}$ brasileira. Referências que estão imbricadas na constituição do sujeito a partir da materialização do sexo e naturalização do gênero, e consequente nomeação de si mesmo, enquanto indivíduo, e das coisas.

Nesse sentido, retomo d'Ors, “pensar es siempre 'pensar con alguien'..." 27 Isto tomando como base a corrente epistemológica que Peirce denomina sinequismo, como a união de tudo o que é, que foi e do que poderia ser.

O self, sobretudo, é um signo em ação. Cada incremento de informação de si implica e é implicado por um incremento correspondente de informação da palavra. (CP 5.313, 1868). Isto porque a palavra é feita pelo ser humano e não significa nada que aquele não haja feito que signifique.

Dado que o ser humano só pode pensar por meio de palavras ou por outros símbolos externos, os dois se educam reciprocamente. Por isso, reconhecer as coisas pelo seu nome é um processo de reconhecimento de nós mesmo, que envolve o ato de nomear e de ser nomeado, ou seja, de agir em acordo com o que nomeamos, em uma relação com a ética agir em acordo com o que se nomeia como mulher e como mãe. A palavra e o self estão em uma constante elaboração mútua, relação que não deixa de estar em tensão:

Desta maneira, "dizer" vai além de 'colocar para fora' algo que estou pensando, é compreender a razão e razoabilidade no que será expresso, um motivo que potencializa a exteriorização de "dizer as coisas". Isso pressupõe o elenco: alter- self e não um soliloquio. Por isso reconhecemos as coisas e a nós mesmos ao nomea-las; descubrir para comunicar. (RUSSI, 2016, p. 166). ${ }^{28}$

\footnotetext{
${ }^{26}$ Esse conceito de Lotman será melhor abordado no terceiro capítulo. Por enquanto, queria apenas explicar que a semiosfera é um espaço signico abstratos, em que estão submersos códigos e linguagens distintos, onde ocorrem formações de sentido. Para Lotman um signo adquire significado na relação com outros elementos dentro desse espaço. Espaço que é dotado de memória.

${ }^{27}$ d'ORS, Eugenio. Diálogos. Ed. de Carlos d'Ors. Madrd: Taurus, 1981, p.28. apud RUSSI, 2016, p. 166.

28 Tradução livre da autora, do original 'De esta manera, 'decir' va más allá de 'sacar para fuera' algo que estoy pensando, es comprender la razón y razonabilidad en lo que será expresado, un motivo que potencializa la exteriorización de 'decir las cosas'. Eso presupone el elenco: alter- self y no un soliloquio. Por eso reconocemos las cosas y a nosotros mismos al nombrarlas; descubrir para comunicar. (RUSSI, 2016, p. 166).
} 
O self, como mente finita capaz de tornar-se um agente autônomo, segundo Peirce (MS 670, 4-7 apud COLAPIETRO, 2014, p. 138), possui necessariamente três forças distintas, que são relativas às categorias. A primeira é a força da consciência de ser; a segunda é a força da resistência às coisas; e a terceira é a de adquirir hábitos - pela e na nomeação - e de livrar-se deles também.

Ao pensar nas mães, entendo que se configuram enquanto selves dotados dessas três forças distintas. Além de se referirem às categorias, as três também estão relacionadas às três Ciências Normativas: Estética, Ética e Lógica. Ou seja, os movimentos do pensamento, que resultam em ações - que produzem sentido, pois pensar é ação e atuar é criar sentido - podem ser analisados enquanto processos que envolvem estética, ética e lógica. Tais processos são o próprio ato de filosofar como ação de vida inevitável, em interações entre trabalho e jogo (d'ORS, 1998). O primeiro refere-se ao esforço de superar resistências; e o segundo, à contemplação de nossos próprios atos.

Importante para o entendimento do self é o caráter de unidade da consciência pessoal, que é condição necessária para conflitos metais e intrapessoais. "Em conflitos interiores, o self sente-se dividido contra si mesmo; isto só é possível se houver uma unidade de sentimento que esteja sendo rompida." (COLAPIETRO, 2014, p. 139). Tornar-se mãe é um rompimento. Vê-se que, para muitas mães, o centro da vida passa a ser outro nesse processo.

E a constituição dessa unidade se dá por um conjunto de hábitos, que podem ser mais ou menos integrados: quanto maior a integração deles, maior será sua unidade. Essa integração envolve adquirir hábitos que influenciam a aquisição de novos. Tal integridade é o que permite que se afirme ser mulher e mãe. O nascimento de um(a) filho(a) traz conflitos, por isso passar a se ver como "outra pessoa" e ter de adquirir novos hábitos.

Enquanto a capacidade de criar hábitos e segui-los está vinculada à possibilidade de crescimento, a capacidade de ser consciente deles garante a unidade do self mãe. Por isso, apesar de considerar-se "outra pessoa", essa capacidade permite que a pessoa entenda suas transformações no tempo como encadeadas na memória do self.

Claro está, com base em Peirce e Mead, que o ato de nomeação não é um ato limitado a um self, pois existe uma estrutura comum entre ele e outros para que possam ser membros de uma mesma comunidade; mesmo que o self não seja apenas aquilo que é comum a outros, já que cada pessoa é distinta das demais. Ele é ele mesmo na medida em que também é membro de uma comunidade. 
Assim, ao abordar as formações de sentido nas memórias das mães, busco por hábitos nessa nomeação, que remetem a uma memória comum. Nesse ínterim, interpreto as configurações nessas memórias com o pressuposto não apenas de que existe algo na constituição de um self que pertence também a outros, mas também de que os selves somente se constituem enquanto tais porque têm memórias em comum - a constituição se dá na relação.

Dessa forma, a concepção do conceito de mãe vai se dando a partir de memórias delas junto a outras pessoas pertencentes à comunidade; por isso, existirem relações muito parecidas, nas entrevistas, como mencionei, a palavras como "doação", "entrega", "transformação", “aprendizado", "amor" - que estão conectadas às noções de completude. Concepções formuladas, reformuladas e reforçadas pelas representações que vemos das mães em objetos diversos.

\subsubsection{Indivíduo, substância, organismo e mente}

Continuando o entendimento do conceito de self, trago as quatro noções enunciadas por Colapietro (2014, p. 137), como pressupostas para o estudo da abordagem de Peirce: indivíduo, substância, organismo e mente.

O indivíduo é um ser individual que reage às coisas no aqui e agora - ou seja, enquanto durar a sua reação a algum outro. No entanto, ele não é apenas isso, pois sua existência não é apenas transitória. Para Peirce (CP 3.613), os indivíduos, em um sentido mais amplo, duram mais que um momento já que a continuidade de reações define sua identidade. Assim, quando dizemos que somos as mesmas pessoas que aquelas que brincavam de boneca quinze anos atrás, estamos afirmando que existe uma série ininterrupta de reações reais que ligam quem somos no instante do agora a quem éramos. Como indivíduos, somos uma continuidade de reações às coisas do mundo. Essa noção de indivíduo está em conformidade com as ideias de unidade e de hábito.

Bianca, 20, fala um pouco do desejo que tinha de ser mãe a partir das brincadeiras, desejo que se foi - e ela pode permanecer sem ele, ou pode ser que retorne.

Não penso em ser mãe. Acho que quando a gente é criança, a gente pensa em ser mãe porque a gente é condicionado a brincar de boneca, então a nossa brincadeira já é um projeto de ser mãe. Então eu acho que eu pensei em ser mãe quando eu era criança e quando eu brincava de boneca. Mas quando eu tinha uns nove, dez anos, eu dei todas as minhas bonecas e não senti mais falta de ser mãe brincando. 
A noção de substância para Peirce está vinculada à ideia do indivíduo no amplo sentido. A regularidade de comportamento é da ordem da continuidade das ações. Tanto regularidade quanto continuidade indicam aspectos de terceiridade, enquanto que a reação imediata indica aspecto de secundidade. "Uma coisa existente nos confronta como um fenômeno complexo e não como um mero segundo; ele exibe terceiridade, bem como secundidade." (COLAPIETRO, 2014, p. 131).

As substâncias, portanto, possuem o caráter de secundidade quando se apresentam em oposição às coisas - que se refere à capacidade de resistência do self ao mundo ao redor, como enunciado no início desse subtítulo. Por outro lado, elas são reconhecíveis por nós em virtude de suas qualidades próprias - primeiridade - e em virtude da regularidade das suas ações - terceiridade. Aquela referente à consciência de ser do self e esta à capacidade de adquirir hábitos.

Por isso, também, o impulso a devolver o bebê para algumas mães ao se depararem com a nova realidade - ou secundidade - e, em virtude de todo o entendimento do que é um ser humano e do que é ser mãe, a terceiridade vem para impedir que se devolva a criança. E a regularidade das ações daquele novo ser vai sendo incorporada à vivência dessa mãe e vai sendo interpretada à medida que esse self, que também é dotado de substância e de hábitos regulares, vai se reposicionando no mundo como uma nova mãe, seja do primeiro filho, seja de um novo. Esse é um processo de estabilização para se reconhecer em sua própria história.

A noção de organismo, conforme Peirce (CP 4.6), é a de que o self, como um signo, possui individualidade e apresenta-se com alguma matéria. Para Peirce (CP 5.3313 apud COLAPIETRO, 2014, p. 39), signos não são expressões da mente, mas a própria realidade da mente é o desenvolvimento de um deles. E para que o self funcione como tal, deve haver corporização, embora a mente, por mais que necessite do corpo, nunca seja reduzida a ele. (COLAPIETRO, 2014, p. 134). "No caso do homem-símbolo, essa forma é fornecida pelo organismo humano compreendido como uma coisa duradoura" (COLAPIETRO, 2014, p. 137).

Isto reforça o que eu vinha falando sobre o self ser um signo e sobre nomear e ser nomeado. As noções de substância e de organismo contribuem para a relação que se estabelece entre mente e corpo - nesse sentido, existe regularidade na constituição do self. Sua identidade se faz também pelo/no corpo. Por isso também ser tão imbricado no entendimento de si enquanto indivíduo o binarismo que se cria com a separação dos corpos em dois sexos e dois gêneros. 
A quarta e última noção assinalada por Colapietro é a de mente. O self é um tipo específico dela. A mente, segundo Peirce (MS 318, p. 18 apud COLAPIETRO, 2014, p. 138), é rudemente definida como um "criador de signo" em conexão com uma "máquina de reação" - esses dois aspectos vistos não de forma dualística, mas como pontos de um contínuo. A máquina de reação está vinculada à regularidade invariável do sujeito consciente, enquanto que o criador de signo refere-se à parte do indivíduo que está mais aberta a novas variações.

Essas duas faculdades da mente acontecem no processo de semiose; no desenvolvimento do signo, que se torna cada vez mais complexo; na continuidade dessa ação. A semiose acontece pelas inferências, que são possíveis apenas dentro da experiência, quer dizer, do encontro com o outro, da linguagem. Pode-se associar a isso, uma vontade inicial de ter filhos, a partir do hábito social de brincar de boneca; e depois, pela abertura da mente a novas variações e relações com o outro, pelo criador de novos signos, a vontade passa, e pode voltar novamente.

Por meio dessas duas faculdades, também, pode-se analisar os processos de reconhecimento da importância da mãe ou de gratidão ao se perceber a nova experiência quando se tem o desafio de criar um filho. Uma importância que não se dava, depois, por conta do "criador de signos", passa-se a dar ao remetermo-nos à memória e inquirirmos a partir da nova experiência. Fabíola, 28 diz:

Quando eu engravidei, várias pessoas me falavam "ah, é muito difícil, é muito difícil", mas eu achava, eu subestimava um pouco, eu acho, é porque eu sempre, sempre, sei lá, eu sempre achei assim, ah... eu sempre dei conta, sei lá, de passar nas matérias, de me formar, de passar na Universidade, de passar num concurso, de fazer não sei o que, e tal... então, tipo, ai as pessoas sempre achavam muito difícil. Eu pensava, ah... gravidez, maternidade deve ser mais ou menos assim, também, eu vou dar conta. Sei lá, se fulana, ou sicrana, que às vezes eu acho elas superfracas, dão conta, por que eu não vou dar conta e tal. Tipo, eu era já um pouco arrogante nisso. E depois que eu pari, que eu fui começando a, sei lá, que veio o primeiro choque de tudo, aí eu lembro que eu comecei a olhar pras pessoas na rua, na televisão, e ver, caramba, todos saíram de uma mãe, assim. Então todos tem uma mãe que passou por isso, tal, sinistro, então eu comecei a admirar muito mais as mulheres que às vezes eu subestimava.

A ação de subestimar as mulheres como uma "máquina de reação", a partir de um hábito da mente acaba se transformando, após o nascimento do(a) filho(a), por conta do "criador de signos". Este último é relativo à primeiridade, equanto àquela se refere à terceiridade. 


\subsubsection{O Sinequismo e o self: processo histórico}

Como já mencionado aqui, de acordo com Peirce (CP 1.357) qualquer coisa é algo em si mesma separada das outras. Ou seja, as coisas sempre possuem um aspecto de primeiridade. Ao reconhecermos a primeiridade do self, estamos vendo ele em sua unicidade e totalidade qualitativa. Quando pensamos nas nossas memórias, sabemos que existe algo delas, algo de primeiridade, que pertence somente a cada indivíduo em particular, ao mesmo tempo em que elas se constituem em diálogos com outros indivíduos.

Conforme Colapietro (2014, p. 113) há três principais momentos de desenvolvimento dos estudos de Peirce sobre o self: a série de artigos publicados no The Journal of Speculative Philosophy em 1867-1868; a série de cinco artigos publicados no The Monist, começando por 1891; e os últimos estudos de Peirce sobre o pragmaticismo.

No primeiro momento, encontra-se uma interpretação semiótica da consciência humana. O conteúdo e o próprio sujeito de consciência são interpretados como signo - o self é um signo, como disse antes. (PEIRCE CP 5.283; 5.314). No segundo momento, existe a articulação sistemática de uma cosmologia evolutiva, com princípios essenciais desta cosmologia, temos o tiquismo, o sinequismo e o agapismo. Nesse contexto, Peirce formulou uma teoria da personalidade. No terceiro momento, existe o desenvolvimento dessa cosmologia, uma evolução que incorpora em si mesma os discernimentos mais fundamentais da reviravolta inicial da semiótica de Peirce. (COLAPIETRO, 2014, p. 114).

Mead (1992) segue a mesma linha de pensamento de Peirce ao considerar os seres humanos como organismos, cuja condição de existência consiste em experiências de interação, cooperação e comunicação. Dessa forma, para ele, a emergência do self e a evolução da sociedade humana são pautadas na linguagem, na capacidade de comunicação e na interação simbólica. Assim, como dito anteriormente, a comunicação é a base estrutural no processo de cooperação. (CASAGRANDE, 2014, p. 3). Nesse sentido, a evolução humana produz-se no discurso, mediante a participação de diferentes indivíduos ao desenvolverem entre si símbolos significantes.

Dessa forma, a pessoa - sendo um self no contexto social vigente - aparece como um sujeito que encontra a possibilidade de reconhecer-se e de referir o sentido de seus atos em direção a si mesmo, em um processo contínuo de encontrar-se em relações com outros sujeitos, que formam parte, de maneira íntima, de sua própria realidade existencial. Assim, o conceito de adaptação utilizado por Mead (1992) está alinhado à capacidade do ser humano de resolver de forma criativa os problemas reais do quotidiano, não significando a simples 
adequação dos organismos às condições naturais. Daí hábitos de ação que caminham em fluxos contínuos de trabalho e jogo, retomando d'Ors (1998).

A diferenciação evolutiva da sociedade humana em relação às outras sociedades animais pauta-se no uso comunicativo da linguagem. (CASAGRANDE, 2014, p. 4). Para Mead (1992), portanto, a subjetividade e a consciência são produtos de diálogos intersubjetivos e de interações simbólicas.

Entendemos, portanto, que uma das mais importantes implicações da teoria psicossocial de Mead centra-se no reconhecimento de que nós somos inscritos numa matriz (matrix) intersubjetiva, numa espécie de rede de relações e de interações a partir da qual emerge a consciência, a identidade individual e um mundo de sentidos, produtos ou efeitos da interação social. (CASAGRANDE, 2014, p. 5).

Pensando nas conexões entre selves, no social frente ao individual, os conceitos normativos encontrados no social são elementos que tentam limitar e conter as possibilidades metafóricas de interpretação. Eles estão expressos nas doutrinas religiosas, educativas, científicas, políticas ou jurídicas e tomam a forma típica de uma oposição binária fixa. Afirmam, de maneira categórica e inequívoca, o significado do homem e da mulher, do masculino e do feminino. De fato, essas afirmações normativas são, às vezes, abertamente contestadas, mas a posição que emerge como dominante é declarada a única possível. A história posterior é escrita como se essas posições normativas fossem o produto do consenso social e não do conflito.

O desafio da nova pesquisa histórica consiste em fazer explodir essa noção de fixidez, em descobrir a natureza do debate ou da repressão que leva à aparência de uma permanência intemporal na representação binária do gênero. Esse tipo de trabalho deve incluir uma concepção de política bem como uma referência às instituições e à organização social - este é o terceiro aspecto das relações de gênero (SCOTT, 1995, p. 95).

Exemplo disso são as crises demográficas - causadas pela fome, pestes ou guerras que, apesar de terem colocado em questão visões normativas de casamento heterossexual (como foi o caso em certos países no correr dos anos 1920), igualmente provocaram políticas pró-natalinas, que insistiam na importância exclusiva das funções maternais e reprodutoras 
das mulheres. Em certo sentido, a história tem sido traçada pelo terreno do gênero, que parece fixo, mas cujo significado é contestado e está em fluxo. (SCOTT, 1995, p. 93). ${ }^{29}$

A história, enquanto ciência, também é um discurso construído. Trago essas formulações desse campo do saber - que vem se redesenhando, a partir principalmente da década de 1970 no Brasil, por vertentes diferenciadas do feminismo - porque entendo que os processos de constituição do self das mulheres, e das mães em específico, têm muito a ver com essas concepções naturalizadas de gênero e sexo. Mas existe, também, a pergunta, que fiz às entrevistadas: “O que maternidade tem a ver com ser mulher?”, ao que recebi respostas diferenciadas. A entrada do feminismo nas várias áreas do conhecimento, nos meios de comunicação e nos diálogos diários dos brasileiros, permite que novas respostas sejam dadas a essa pergunta. Essa é a da Clara, 30:

Maternidade tem a ver com ser mulher? Não, eu acho que isso é muito relativo porque não faz diferença, né? Tem mulher que não vai querer ter filho, não quer dizer também que ela não é uma pessoa maternal ou que ela é menos mulher por isso, né?! Mas acho que, pra quem quer ter filho, eu acho que a maternidade acaba complementando a pessoa, a mulher. Mas também acho que uma coisa é bem distanciada da outra. Porque também tem homens que também vão fazer o papel da mãe ou maternal.

Vale notar a aproximação entre as formulações da teoria feminista e a valorização da cultura pelo assim denominado pós-modernismo. Nesse contexto, a História Cultural vem sendo trabalhada pelos historiadores e historiadoras enfatizando a importância da linguagem, das representações sociais culturalmente constituídas e esclarecendo que não há anterioridade das relações econômicas e sociais em relação às culturais.

\footnotetext{
${ }^{29}$ Esse discurso, que traz a noção binária dos sexos e gêneros, é visto em outras áreas do conhecimento e, muitas vezes, trazendo a hierarquia entre os dois. Na psicanálise de Lacan, "o falo é a parte da falta e, em geral, da diferença, e, em particular, da diferença sexual. Como a marca da falta, refere-se ao fato de que o sujeito não está completo em si mesmo. [...] Como marca de diferença em geral, o falo está aliado ao logos, ao princípio de que o reconhecimento da diferença é a condição da lógica e igualmente da linguagem. Quer dizer, o pensamento, como tal, exige a diferença. Isso nos leva à asserção crítica lacaniana de que a diferença sexual é a diferença crucial para que se possa falar e, portanto, pensar; e, mutatis mutandis, de que falar é crítico para a diferença sexual. [...] Pelo fato de parecer mais visível, e porque pode representar a falta, o pênis ocupa o lugar do falo potencialmente neutro. Em outras palavras, num plano não-visual, o falo não deveria ser senão um sinalizador neutro: um significante que nada represente, ou nada mais represente do que aquela falta que nos impele a falar, e, ao falar, nós nos diferenciamos. Entretanto, ao ligar o corpo a esse processo de reflexão, nós confiamos na representação visual da diferença sexual. Daí que o falo idealmente neutro é representado de um modo masculino unilateral. E não é só isso: a oposição feminina, como oposta à posição fálica masculina, é considerada desprovida de conteúdo, nada mais do que a diferença em relação ao masculino. As feministas influenciadas por Lacan enfatizaram que ambos os sexos podem ocupar o lugar masculino e o feminino; estes se alteram e se deslocam nenhum deles contém o falo. No entanto, o vínculo entre o falo e o pênis existe, e persiste. (BRENNAN, 1989, p. 14).
} 
Rago (2000, p. 8) fala da dificuldade de se configurar a epistemologia feminista sem tocar na discussão sobre os perigos da reafirmação do sujeito "mulher" e de todas as cargas que essa identidade traz no imaginário social. Afinal, a questão das relações sexuais e da mulher especificamente nasce a partir das lutas pela emancipação desse sujeito antes definido como "sexo frágil". É na luta pela visibilidade da "questão feminina", pela conquista e ampliação dos seus direitos específicos e pelo fortalecimento da identidade da mulher que nasce um contradiscurso feminista e que se constitui um campo feminista do conhecimento. É a partir de uma luta política que nasce uma linguagem feminista. E é esse novo olhar que permite reler a história da colonização no Brasil.

Durante o processo desta dissertação, foi-me perguntado o que eu faria em relação aos homens, onde é que eles entrariam, por que eu não os entrevistaria, já que compõem o social. Tomando como pressuposto que este discurso que faço está, também, atrelado a uma ideologia e possui um viés político, tenho a liberdade de propositadamente dar o protagonismo às mulheres. Os homens entram aqui nas falas delas, haja vista que este assunto diz respeito muito mais a elas, embora eu tenha conversado a respeito com alguns deles nas ocasiões que chamo aqui de "jogar conversa fora".

Enquanto escrevo, lembro-me de várias conversas sobre maternidade, recordo-me de um grupo em que mães que perderam os filhos se encontram para desabafar; penso nas mães levando os filhos aonde vão; lembro-me das mães que abandonaram as crianças, que esconderam a gravidez; lembro-me das mães que acreditaram no sonho de construir uma família; penso na ideia que muitos trouxeram da presidenta Dilma como mãe do Brasil, ela que foi a primeira mulher a atingir esse posto. Lembro-me, principalmente, da relação que tenho com minha mãe, que me ajuda e apoio sempre que preciso. Penso, também, na relação dela com minha avó e na nossa família de gerações marcadas pelo matriarcado.

Escrever sobre as mães é também lembrar-se de sofrimentos, de silêncios que percebo agora ao ouvir novamente as entrevistas, de palavras engasgadas. Escrever sobre as mães é, também, pensar na luta diária dessas mulheres, desamparadas pelo Estado brasileiro, que sempre entendeu que esse é um assunto privado. Penso nos desabafos que não tenho coragem de expor aqui. Penso nas mulheres que não quiseram ser entrevistadas dizendo que não gostavam de falar sobre o assunto, pois "provoca dor"; ou que não quiseram, afirmando que não eram "exemplo para ninguém". Penso na responsabilidade, na doação, na culpa dessas mulheres.

Quando escrevo sobre maternidade e sobre configurações na memória do self mãe, estou atrás dessas histórias individuais, mas que só são possíveis pelo, e através do social. 
Enquanto constituídos como seres históricos, dotados de memórias, capazes de registrar traçados e caminhos de outros tempos. Remeter-me a uma nova concepção de história é fundamental para entender que as memórias sociais estão sendo reconfiguradas por outras vozes. A história feminista vai de encontro à predominante do imaginário androcêntrico, da ideologia patriarcal, que ainda é ensinada nas escolas brasileiras, em que ainda existe a emblemática imagem de uma mulher sendo rastejada por um homem na idade da pedra.

Os feminismos formam processos que vemos se desenrolar no social, que permite às mulheres, e à sociedade em geral, criar novidades possíveis para as imagens que são feitas da mãe. Retomando as três categorias de Peirce, o que era primeiridade, uma possibilidade, vai sendo decodificado em terceiridade.

As ideias feministas, que vão avançando a partir das fronteiras da semiosfera brasileira desde meados da década de 50 em direção ao centro são o que permitem que as mães que entrevistei e as conversas que tive trouxessem signos diferentes da monótona narrativa do mesmo patriarcado. São esses processos de entendimento que permitem que novas concepções do conceito de mãe desemboquem em exigências a direitos como o aborto, o aumento da licença paternidade, a diminuição da jornada de trabalho da mulher nos meses seguidos à licença maternidade até que o filho complete um ano de idade, etc...

No próximo capítulo, abordarei aspectos específicos da memória, de como estou a entendendo como constituição simbólica. Para compreender os processos de significação do self enquanto se constitui e age, trarei os conceitos de ícone, índice e símbolo. São eles que me ajudam a trabalhar a noção da "personalidade como coordenação de ideias", que será abordada, também, no próximo capítulo. 


\section{Capítulo 3}

\section{As formações de sentido no self mãe}

Eu ouvi dizer, amor, eu ouvi falar, Eu ouvi dizer, amor, eu ouvi falar, Que a filha chamou a mãe

"Cabelo de arapuá"

(Corrido de Capoeira Angola)

Essa noção de que o feminismo possibilita novas leituras sobre a maternidade por parte do social é interessante de ser observada, pois ela aparece nas entrevistas e nas conversas que tive no percurso da pesquisa como um hábito que vem sendo constituído no self das mães. Isto é o que permite que se questione as relações de completude e incompletude, associadas à figura materna e à mulher sem filhos, ou mesmo as noções de completude e incompletude, que seguem a mesma lógica de um papel social da mulher pautado na ideia da gestação.

Seguindo essa linha de raciocínio, enfatizo aqui as categorias de interpretação já mencionadas algumas vezes nesta dissertação: memória-esquecimento, isolamentocomunhão. Só gostaria de reforçar, como apontei anteriormente, que alguns conceitos centrais do feminismo da classe média branca, como as noções de patriarcado, reprodução e família são vistos de forma diferente pelo feminismo negro ${ }^{30}$. Portanto, também, um conceito central na minha dissertação, que é o de reprodução é visto de forma diferenciada no feminismo negro.

Com isso, enfatizo novamente desde que lugar eu estou falando porque não quero incorrer no erro de invisibilizar as mulheres negras. Por isso, enquanto apresento as falas das entrevistadas neste texto, contextualizo brevemente suas vivências familiares e explicito dados como cores e classe social. Isto tomando o cuidado do anonimato dessas mulheres. Tento, com a exposição dessas diferenças, trazer um pouco das contradições que existem nos

\footnotetext{
${ }^{30}$ No trajeto da pesquisa, tive a oportunidade de conhecer algumas feministas do feminismo negro e elas apontaram a questão de essa valorização toda atribuída às mulheres brancas de classe média através da reprodução, não ser na mesma proporção em relação às mulheres negras. Alguns casos relatados em sala de aula apontam justamente para o contrário, para um discurso, por parte dos médicos em especial, que vá contra a reprodução dessas mulheres.
} 
discursos por conta da relevância fundamental das relações de poder que são estabelecidas entre classes, gêneros e raças.

As categorias de análise são pensadas notando-se que o self encontra-se em contínuos processos e relações com outros selves e com o mundo ao redor. São categorias analisadas, portanto, a partir da percepção do sinequismo. Dessa forma, retomo novamente a questão-problema: como o self mãe cria forma? Essa é uma pergunta que vem sendo colocada, instigada e analisada continuamente nesta dissertação, e não apenas neste último capítulo. Mas este é um momento de privilégio porque vários conceitos que ajudam na análise já foram abordados anteriormente e me sinto à vontade para retomá-los e conectá-los nesta "chamada" que proponho agora.

A "chamada" que faço neste capítulo não é uma virada de jogo, mas uma continuação do que se estava propondo, é como dizer "vamos continuar", mas de forma a instigar o outro a continuar e a se imbricar no que está sendo proposto. E não apenas uma continuação pela continuação, com um sentimento já quase tedioso. Eu considero o presente capítulo fascinante porque muito do jogo já foi colocado, então muito da potência da primeiridade já virou, no mínimo, uma secundidade.

\subsection{Personalidade como coordenação de ideias}

Pensando nas transformações no self, adquiridas no tempo - no sentido cronológico e simbólico (que acontece em retomadas constantes). Pensando, também, que tais transformações são elaboradas a partir da nomeação que se faz da mãe por parte das mulheres entrevistadas, que pertencem, obviamente, ao social. Levando em consideração, ainda, que essas reconfigurações, que se apresentam em retomadas constantes a situações passadas, podem ser vistas a partir de um discurso feminista tanto por parte das entrevistadas quanto por minha parte, uma pergunta que faço às mães entrevistadas é a seguinte:

- Existem diferenças entre você no início da sua vida enquanto mãe e agora?

Essa pergunta me trouxe a possibilidade de entender melhor as formações de sentido ao longo do tempo. Com ela, trago principalmente a categoria memória-esquecimento e identifico nas respostas os hábitos das mães, que envolvem as outras características de análise já mencionadas aqui.

A partir do sinequismo, de Peirce, a personalidade é definida como uma coordenação de ideias, que não estão organizadas apenas para um fim predeterminado, mas em contínuo processo evolutivo. Essa teleologia evolutiva constitui o caráter pessoal. "Uma ideia geral, 
palpitante e vívida agora, já é determinante de atos no futuro em um nível que não é agora consciente" (PEIRCE, 6.156). A personalidade é, portanto, uma força viva no presente, orientada em direção a um futuro não determinado - sem deixar de perceber que o presente se constitui com a memória do passado. Essa conexão entre ideias desenvolve uma ideia geral crescente, sentimento vivo. (PEIRCE, 6.155). E as ideias não podem ser outra coisa fora da personalidade, elas existem apenas no self.

Por isso, ao falar de memória, estou visualizando-a desenvolver-se por meio de interconexões entre ideias, que são transformadas pelos contínuos contatos entre si, gerando novas ideias e novas relações. Isso é o que faz expandir a personalidade do self, seguindo uma organização interna, que não é linear e uniforme, e que ocorre em níveis de semiosfera de Lotman.

Penso na noção de semiosfera tomando como base que no self existe um fluxo de textos - advindos das experiências e referências próprias de cada um - que vai aos poucos recompondo a memória, recente ou longínqua - o bebê que acaba de nascer, ao ser visto novamente um minuto depois pela mãe, já se modificou para ela. Isso ocorre porque o self já se transformou.

Em novos contextos, experiências da maternidade (o próprio ato de brincar de boneca quando criança, ou a experiência de cuidar de uma criança, uma irmã ou irmão) sensações em esquecimento na mente - retornam de forma distinta, reconstruídas pelos elementos que foram sendo organizados e correlacionados no decorrer do tempo simbólico e cronológico, e ainda pelos latentes no instante em que se recorda. Imagino novos signos sendo criados a partir de outros já existentes nos processos de releituras a novos contextos. Vânia, 57, fala um pouco de experiência que teve na infância. No novo momento, após ter tido filhos, é possível que reconfigure a memória a partir da ideia do amor materno:

- Você se lembra de ter sentido amor materno na sua infância?

- Ah... tá... aquele negócio de você gostar muito de um bebê, né? Mas não é amor materno, não. Mas eu não lembro de nenhum bebê na minha família. Ah... tinha, tinha a Vanilda. Ah... tinha sim! Tinha minha irmã! Minha irmã nasceu, eu tinha oito anos e eu gostava demais dela. Mas eu não sei. Eu adorava a Vanilda! E ela me adorava! Então acho que é mais ou menos o amor materno. Você tem aquele carinho por um bebê, por uma criança.

- Um cuidado, né?

- É, um cuidado. Eu gostava de dormir com ela. Nossa... Até assim, coisa de mãe mesmo. Porque, assim, ela sempre pegava piolho na escola, eu nunca peguei. Eu acho que eu devo ser meio, meio tóxica, assim, sei lá. Ai eu lembro que ela vinha dormir comigo cheia de piolho eu nunca briguei porque... minha mãe até falava "não vai lá, não porque você vai pegar piolho na Vânia." Mas eu deixava. Eu nunca peguei também, mas... eu não tinha 
medo porque eu gostava demais da Vanilda, se pegasse, pegava, não me importava. Isso é coisa de mãe, só a mãe que faz isso.

Esses textos e linguagens, que compõem as experiências do self, são organizados de tal forma, a partir dos diálogos que vão sendo criados entre si, que se pode entendê-los como dispostos em estruturas nucleares submersas em um mar de elementos cada vez mais informe. Sempre que, em um relato, uma lembrança específica é retomada, ela passa a ocupar posição dominante e se eleva ao estado de autodescrição, então, acima da irregularidade do mapa semiótico real, se constrói seu nível de unidade ideal.

Nesse sentido, uma lembrança recordada por uma das entrevistadas para descrever sua experiência enquanto mãe passa a ocupar lugar central na semiosfera de sua memória em um processo de autodescrição. Na entrevista, essa experiência colocada no centro torna-se a referência do que é sua experiência enquanto mãe. Ao ser questionada sobre o que vem à mente quanto pensa na palavra mãe, Vânia responde:

-A minha experiência de ser mãe foi essa. Parece que é uma coisa do corpo, o corpo exige aquilo, parece que chega uma época que você tem. Parece que é uma coisa biológica, né, também. Então é uma vontade muito grande de ser mãe.

- Então você disse que maternidade tem a ver com uma coisa mais biológica?

- Não, é muito biológica também. Depois vêm outras coisas também porque parece que depois que a pessoinha nasce então assim tudo é novidade. Então você tem a responsabilidade. Você é totalmente responsável por aquele serzinho que nasce, assim, não tem ninguém mais. Pelo menos para mim era eu, eu tinha que fazer tudo por aquela pessoa.

Interessante pensar, também, a partir de Lotman (1996, p. 18), que a irregularidade em nível estrutural é complementada pela mescla dos níveis. $\mathrm{Na}$ realidade do espaço semiótico, por regra geral, se viola a hierarquia das linguagens e dos textos, o que permite que, além de encontrarem-se submersos em linguagens que não correspondem a eles, sejam decifrados por códigos que estejam ausentes do todo.

Imaginémonos la sala de un museo en la que en las diferentes vitrinas estén expuestos objetos de diferentes siglos, inscripciones en lenguas conocidas y desconocidas, instrucciones para el desciframiento, un texto aclaratorio para la exposición redactado por metodólogos, esquemas de las rutas de las excursiones y las reglas de conducta de los visitantes. Si colocamos allí, además, a los propios visitantes con su mundo semiótico, obtendremos algo que recordará un cuadro de la semiosfera. (LOTMAN, 1996, p. 18). 
A heterogeneidade estrutural do espaço semiótico forma reservas de processos dinâmicos e é um dos mecanismos de produção de nova informação dentro da esfera. Nos setores periféricos, organizados de maneira menos rígida e possuidores de construções flexíveis, os processos dinâmicos encontram menos resistência e, portanto, se desenvolvem mais rapidamente.

A criação de autodescrições é um fator que aumenta bruscamente a rigidez da estrutura e faz mais lento o desenvolvimento dela. Entretanto, os setores que não foram objeto de uma descrição ou que foram descritos em categorias de uma gramática estrangeira, inadequada a eles, se desenvolvem com mais rapidez. Esse movimento faz transladar a função de núcleo estrutural à periferia da etapa anterior e a conversão do antigo centro em periferia.

Nesse sentido, é possível perceber nas falas o que estaria no centro da semiosfera como autodescrição do self mãe a partir das entrevistas. Muitas entrevistadas concordam com a ideia da completude na experiência da mãe. Muitas falas estão no sentido de colocar os(as) filhos(as) como centro da vida. Ou seja, a autodescrição deixa de ser dada pela mulher enquanto indivíduo e passa a ser dada a partir do referencial do(a) filho(a).

- E quando você pensa na palavra mãe, o que vem a sua mente?

- Acho que eu penso na complexidade da coisa toda mesmo. Maternidade eu acho que é uma coisa que transforma muito a vida de uma pessoa. Ela revoluciona de forma irremediável. A pessoa nunca mais é sozinha, assim, ela passa a ser duas pra todo o sempre. Não sei. Você era uma pessoa e agora você é uma pessoa mãe, então já muda completamente todo o seu, toda a sua vida, porque você nunca mais vai ser sozinha. Tudo que você fizer, desde as coisas mais simples, como beber água, ir ao banheiro, como as coisas mais complexas, como planejar uma viagem, um curso, uma profissão, tudo vai estar influenciado por esse ser que agora faz parte da sua vida. Então maternidade me vem sempre essa ideia da transformação na vida.

(Fabíola, 28)

- Você se acha parecida com outras mães?

Com outras? Não, acho que até hoje eu não encontrei uma pessoa, assim, próxima a mim que fosse, que tivesse a mesma personalidade como a mim em relação à filha.

É?

É, porque geralmente as minhas amigas são mais avoadas, sabe, em relação à maternidade. Pensam mais em si. Eu sou mais pra ela, de certa forma.

- Suas amigas tiveram filho cedo?

- Cedo, minha outra amiga teve primeiro, só que assim, elas pensam mais, assim, visam mais ela. Primeiramente, eu acho que eu viso ela mais como prioridade do que eu. Ah... se eu tiver que comprar alguma coisa, eu compro pra ela. Depois pra mim, né? Mas as minhas amigas, assim, sempre foram diferentes em relação a isso. (Roberta, 22). 
- Como você falou agora, você vira uma mulher mesmo, isso quer dizer uma mulher madura?

- É exatamente, a maturidade, você cria, você tem mais maturidade, quando você não tem criança, você não tem que se preocupar com nada, você se preocupa só em sobreviver e ponto, não a partir do momento que você tem uma criança, que você cria amor por ela você já tem esse amor, você vai fazer o que, não, tudo que você for fazer será para ela, não será mais para você, é isso que eu penso. (Cordolina, 28).

Voltando à noção de que a personalidade é uma coordenação de ideias, que estão organizadas em um contínuo evolutivo; as ideias são fenômenos mentais que tendem, na ausência de qualquer impedimento, a integrações que se complexificam em sínteses de alcance cada vez maior, pois é da própria natureza delas espalharem-se. "Neste espalhamento elas perdem a intensidade e, especialmente, o poder de afetar a outros, mas ganham generalidade e unem-se a outras ideias" (PEIRCE, 6.155).

A personalidade, como uma ideia geral que liga outras ideias, não pode ser apreendida em um instante, mas é vivida no decurso do tempo - ela é essencialmente temporal e, portanto, inerentemente irrealizável. Portanto, essas mães não podem ter a compreensão geral de quem são. "A pessoa é, em certo ponto, consciente do presente e, de maneira mais extensa, inconsciente do curso de sua vida. Pessoas são sempre simultaneamente quem foram, quem são agora e alguma coisa outra e mais do que isso." (COLAPIETRO, 2014, p. 124). Por isso, as configurações do self mãe são vistas como processos que ocorrem sem um fim determinado, mas como ideias que vão sendo ligadas a outras a partir da nomeação do que é ser mãe.

O futuro, nesse sentido, envolve a possibilidade de tomar caminhos diferentes daqueles traçados por propósitos definidos e perseguidos no presente. Se os fins de uma pessoa já estivessem explícitos e estabelecidos com antecedência, não haveria espaço para o crescimento do self, para a vida em sua espontaneidade; não haveria, portanto, personalidade. (PEIRCE, 6.157). Por isso, ao pensarem no passado, as mães trazem as mudanças que foram se configurando nas formulações e reformulações da experiência; modificações que não eram perceptíveis na época, mas que foram sendo constituídas no tempo (cronológico e simbólico). Sobre a vontade de ser mãe, Fabíola (28) diz:

- Mas aconteceu alguma coisa para te fazer ter essa vontade?

- Conscientemente, assim, eu acho que tem muito a ver com o fato de que eu sempre morei, nunca tinha morado sozinha, aí de repente eu tava num estado a $2000 \mathrm{~km}$ da minha família, morando sozinha, tanto é que eu pensava que ia ficar sozinha mais tempo. Com uma semana morando lá eu já tava com um companheiro, assim, que já ficava praticamente todos os dias junto, e aí acho 
que eu... acho que inconscientemente foi surgindo um pouco essa vontade de ter algo pra completar assim, não sei, uma coisa assim, uma companhia familiar, não sei, construir uma família e tal porque eu já tinha me afastado da minha. Acho que hoje eu penso que tem muito a ver com isso, mas na época eu pensava muito porque o namorado que eu tava, meu namorado, que agora é meu companheiro, é uma pessoa que eu sempre admirei muito e tal, e ele já tinha tido experiência de ter tido alguns abortos na história dele, nunca teve filhos e tal, já tava com 40 anos e ele tinha muita vontade de ter também.

Nos processos e formações dos hábitos e leis que se constituem no self mãe pela relação com o conceito abstrato "mãe", pode-se observar a presença constante da criatividade genuína do acaso. Um signo isolado de futuros interpretantes é um signo ao qual é negada a possibilidade de cumprir com sua essência; ele é a negação da semiose. O self como um signo não pode, portanto, ser destacado de seus futuros desenvolvimentos, ou lhe é negada a possibilidade de atualizar sua essência. (PEIRCE, 5.317).

\subsubsection{O self e as possibilidades da primeiridade}

Pensando nessa potência que o self mãe tem de ir se complexificando por meio das relações entre as ideias, que vão fazendo o signo se expandir. Ao olhar para trás, as entrevistadas não sabem exatamente o que as fez tornarem-se quem são no momento da entrevista - e o que são já é em si um processo contínuo de transformações - e nem quais circunstâncias as trouxeram pelo caminho percorrido. As mudanças na vida não dependem apenas da vontade consciente do indivíduo. Os desejos de criança não foram todos concretizados e a personalidade transformou-se de modo incontrolável, por meio da coordenação das ideias. Mas a memória é uma chama que conecta o presente ao passado e as faz presumir que viveram determinadas situações e que eram realmente elas que estavam lá, por mais que seus planos tenham seguido caminhos diferentes.

Para Peirce (PEIRCE, 6.157), um futuro ainda sem contornos é fundamental para a constituição da personalidade. Assim, ao olhar o passado e pensar no por vir, o self percebe que a realidade do aqui e agora "estaría constitutivamente rodeada por una penumbra de posibilismo, de "caminos no tomados"” (ANDACHT, 2006, p. 3). Graças a esse salto possibilista, encontra uma solução inesperada, móvel, flexível para o que, a princípio, pode parecer um caminho fechado e rígido. É nesse sentido que, ao serem questionadas sobre as transformações ocorridas em si na trajetória da maternidade, as mães percebem as diferenças do antes e do momento da entrevista: 
- Agora, você consegue lembrar de antes de você ter filho, qual era a ideia que você tinha de maternidade, quando você pensava na sua relação com mãe como é que era, como você poderia ser como mãe?

- Achava que eu ia, ia ser tudo fácil, porque eu ia ser muito compreensiva, muito paciente, muito divertida e assim a gente viveria sempre felizes brincando juntas, de mãos dadas, fazendo todas as coisas super-felizes, divertindo. Nunca encontraria conflitos e transtornos e, se encontrasse, eu ia saber facilmente dar a volta e mostrar uma situação divertida para encararmos. [...] Agora vejo essa coisa mais real da maternidade, essa realidade de compreender o amor, mas compreender também que muitas vezes tem conflitos ali, tem desrespeitos, tem mágoas, sei lá, tem expectativas às vezes frustradas, não vejo perfeição, vejo essa coisa humana mesmo.

Essa fala é de Marinalva, 29, que mora em Brasília com a filha de 3 anos e o companheiro. Ela conta que a imaginação era algo mais perfeito do que a realidade bruta. Ela traz a referência dessa realidade tanto na relação com a filha quanto com a mãe. Essas são associações que os próprios processos de organização das ideias vão possibilitando

A espontaneidade no modelo triádico de Peirce é um ingrediente vital que contemplamos e exercemos ao mesmo tempo em que lutamos contra a regularidade e previsibilidade da terceiridade. A imaginação livre de relações objetivas e as expressões espontâneas do corpo e da mente são o que nos possibilitam, ao olharmos o presente e os feitos que nos limitam a determinado lugar e tempo, sonharmos outros de nós mesmos e outros caminhos e crescermos. Dessa forma, os motivos particulares que levam uma mulher a querer tornar-se mãe são decorrentes desses movimentos constantes:

- Ah, eu achava que eu ia ser, que eu ia me engrandecer muito, que eu ia me tornar uma pessoa mais pé no chão, mais ligada ao trabalho, mais produtiva trabalhando, por conta da necessidade de ter que criar, achava que eu ia perder várias das minhas angústias, sabe angústias de querer sair, de querer encontrar pessoas, de querer estar na rua, sei lá, achava que um filho ia me dar vários, sentimentalmente ia diminuir muito minhas ansiedades sociais. (Marinalva, 29).

- O que mudou em você desde o inicio e agora?

- Mentalmente, assim? Mais responsabilidade com as coisas. Eu era responsável, assim, desde quando casei, né, que eu casei nova, com 16 anos, mas depois que eu tive ela a responsabilidade dobrou. Eu vejo tudo com mais responsabilidade. Eu não tinha essa responsabilidade antigamente, que eu tenho hoje.

- em relação a que por exemplo?

- a tudo, assim, financeiramente, a organização das coisas. Antes eu era mais desajeitada com tudo. Financeiramente. Não ligava, pegava meu salario 
gastava só com roupa, essas coisas. Futilidade, de certa forma. Hoje não, hoje eu tento construir algo... pra ela. (Roberta, 22).

- Eu acho que eu era muito ... meu pensamento, meu dia-a-dia era outro, eu era muito afoita, qualquer coisinha eu brigava, então mudei isso, aí que eu falo, agora eu começo a agir diferente, não é, eu não quero mostrar para o mundo que eu sou daquele jeito, eu fui, não é, então hoje, é igual eu falo, a gente amadurece, não é? Então acho que eu era muito afoita, isso, qualquer coisinha brigava...

- Mas por que você brigava?

- Brigava o que eu falo assim, a pessoa não podia falar comigo, eu achava que era dona do mundo, achava que era perfeita, então discutia, brigava, hoje não, hoje você começa a ter mais educação não é, perante a sociedade. (Cordolina, 28).

Assim, o self percorre o processo de desenvolvimento de uma razoabilidade evolutiva na inseparável união entre o crescimento da razoabilidade, a liberdade e a criatividade humanas. Essa criatividade que a primeiridade permite é uma propriedade intrínseca da razão humana, definida como a capacidade de crescer, não sendo, portanto, patrimônio de poucos, mas característica central dessa razão.

Ela também não é um fenômeno pontual, algo de um momento passageiro de inspiração, mas algo que está presente em todos os nossos atos e pensamentos. "Cada cosa que hiciéramos podría ser creativa y esa constancia sería precisamente la que nos permitiría dar una continuidad a nuestro vivir, crecer como seres humanos.” (BARRENA, 2008, p. 12).

Nos encontramos nuevos al renacer, surcando raudos por el proceso del self como determinación semiótica creciente. En cambio, cuando nos encontramos enfundados en la camisa de hierro inclemente de una única identidad asfixiante, esto nos lleva a creer que ya no hay donde ir, ni qué soñar, pues la imagen y el cuerpo se han confundido en una inmóvil y conformista posición. Todo el ser entonces se agota en esa identidad inamovible. (ANDACHT, 2008, p. 6).

Andacht (2008, p. 2) apresenta a "identidade" como um produto interpretativo manifesto, específico, que se fixa em um momento dado da história de uma pessoa ou de uma sociedade - como exemplo, pode-se citar a ideia do padre, do funcionário, ou a de pertencer a certa etnia ou nação -, manifesta pela terceridade. E, em contrapartida, desenvolve o conceito de self, entendido como o signo que evolui em um contínuo movimento interpretativo, que é muitas vezes inconsciente.

A semiose humana discorre entre um limite de segundidad que bordeia com o não-semiótico, a coisa que empurra e resiste, e um de primeridad, do que é 
abertura, puro jogo criativo e visionário, do que ainda não é mas que também não é futuro provável e regularizador, senão mero instante vibrátil, flutuando no limbo do concebível e interpretável. (ANDACHT, 2006, p. 4). ${ }^{31}$

A possibilidade livre da categoria do primeiro é uma espécie de ligeira brisa, que emerge com caráter apenas sugestivo, mas consegue alterar por completo o curso de nossas vidas. Esse estado de sentimento, essa iminência do acontecer, tão leve e sutil como uma "burbuja de jabón" é suficiente para que se ponha em movimento a roda viva de nossos caminhos. "Esa hegemonia de la primeridad, aún si pasajera, hace que esos momentos merezcan ser llamados 'estéticos', aunque nada tengan que ver com la creación de uma obra de arte, del tipo que sea.”. (ANDACHT, 2008, p. 42).

Indo por essa linha de raciocínio, pode-se pensar também que o gênero, abordado no segundo capítulo deste texto, constituiria uma "identidade fixa", ou seja, nasce-se homem ou mulher, com toda a carga de memória cultural que isso significa e, então, as mulheres entrevistadas nasceriam programadas para agirem de determinada forma que fosse totalmente de acordo com a noção que se tem do que é ser uma mulher. Mas os próprios conceitos não são fechados em um significado único, e é por isso que esta análise que faço é possível, porque o conceito não é fechado e as experiências de cada uma das mães entrevistadas seguem e não seguem ao mesmo tempo hábitos, crenças relativas a tal conceito.

Nesse sentido, uma mulher seguir a ideia de querer ser mãe para se sentir mais completa não é algo certo e fechado. Ser mulher, em si, não é uma determinação. Mas nas configurações de si mesmas enquanto mães, instiga-me a relação da mãe com a mulher, já que, como mencionei no capítulo anterior, o binarismo entre homem e mulher é bastante presente em nossa cultura, o que supostamente levaria a identidade de uma pessoa a ser estabelecida a partir dele. Então fiz a seguinte pergunta nas entrevistas: - o que a maternidade tem a ver com ser mulher?

- Uai, tem tudo, né? A maternidade é do lado feminino, né? O homem colabora com, né, o...espermatozoide. mas ele deve também contribuir com amor, com educação, com apoio. (Rute, 57).

\footnotetext{
${ }^{31}$ Tradução livre da autora, do original "La semiosis humana discurre entre un límite de segundidad que bordea con lo no-semiótico, la cosa que empuja y resiste, y uno de primeridad, de lo que es abertura, puro juego creativo y visionario, de lo que aún no es pero que tampoco es futuro probable y regularizador, sino mero instante vibrátil, flotando en el limbo de lo concebible e interpretable." (ANDACHT, 2006, p. 4).
} 
- Assim, eu acho que. Tem muitas opiniões, mas eu acho que o filho completa a gente. Não como mulher, mas assim como uma pessoa mais completa, feliz. Eu acho. Eu sinto isso. Eu não me arrependo de ter tido ela nova.

- Como é que é essa completude? Por que você acha que o filho acaba completando?

- Porque, de certa forma, eu me sentia sozinha, assim, sabe. É... as pessoas. Em relação às pessoas, eu me sentia muito sozinha, sabe? Um vazio. Hoje, em relação à separação, eu não to sozinha. Então isso pra mim é mais fácil encarar uma vida sozinha porque eu não vou tá sozinha, eu vou ta com ela, né? Então, tipo assim, não tem momento pra tristeza, eu sempre to com ela. Então eu acho que te completa, sabe? Cê nunca vai ta sozinha. De certa forma, né. Até um certo tempo. Mas depois que crescer. Mas é uma companhia que você tem, sabe, uma boa companhia. (Roberta, 22).

- Muito. Na verdade tem muito a ver porque quando a gente engravida, a vida de um filho, a responsabilidade maior é pra ela, né? $\mathrm{O}$ pai às vezes não dá a assistência que deve. $\mathrm{O}$ pai de modo geral, ele não cuida como a mãe. Essa é a minha experiência de vida, que eu tenho. (Maria, 54).

Apesar de uma identidade constituída a partir da noção do que é ser mulher, e de uma suposta oposição entre mulher e homem, as mulheres enquanto selves têm a possibilidade de ir se constituindo por esse entendimento e por outros, advindos dos próprios questionamentos a respeito dos papéis sociais estabelecidos por esse binarismo e das hierarquias que surgem daí. Com a possibilidade da inquirição e de novas ideias, pode-se inclusive, ir contra o que está estabelecido, em um movimento estético garantido pela primeiridade.

- Eu acho que tem a ver nas cobranças, nas limitações, nas dificuldades que a gente tem no mundo. Não é que toda mulher vá ter filho, ou tem necessidade de ter filho. Houve um dia que eu pensei nessa possibilidade. (Fabíola, 28).

- Com ser mulher. Eu acho que é exatamente isso, maternidade não tem nada a ver com ser mulher. Você pode ser uma mulher completa, feliz e realizada, independente da maternidade. Eu acho que a maternidade ela tem a ver com o indivíduo, inclusive uma mãe pode ser uma tia, pode ser uma avó, pode ser um pai, pode ser, sabe, pode ser... pode ser qualquer pessoa que vai assumir a educação de uma criança e vai fazer por ela todos esses cuidados inerentes a esse papel maternal né .... vai suprir de amor, de alimentação, de tudo. Então uma mãe pode ser qualquer indivíduo na sociedade e uma mulher pode ser qualquer coisa, inclusive não ser mãe. (Fátima, 36).

Pensar o hábito de enxergar a maternidade como algo que completará a mulher - que naturalmente a mulher virá a ser mãe, e que essa função acaba por distanciá-la da vida política e da cidadania - faz perceber que a maternidade, vista por esse viés, como discutido durante este texto, é encarada como assunto da esfera privada. Maternidade e política, por essa 
perspectiva, são mutuamente excludentes. Mas, se a maternidade representa o que exclui as mulheres da cidadania, ela também é constuida como status político. Nesse sentido, ela existe como um mecanismo central através do qual as mulheres são incorporadas à ordem pública. ${ }^{32}$

Dessa forma, existem os enfoques que a consideram uma experiência privada característica da identidade feminina construída em torno da mulher-mãe, distanciada em seu lar e subordinada aos valores do casamento e ao homem na esfera doméstica. Por esse caminho, se reconhece na mãe unicamente seu poder afetivo sobre os filhos(as). Por outro lado, a maternidade pode ser uma experiência pública, cujas práticas vinculam as preocupações pelos próprios filhos e filhas e por questões coletivas. Esta é uma forma de encará-la também como experiência política e como instrumento de transformação social.

Esta última concepção pode ser entendida por mutiplos ângulos. Penso em mães que, preocupadas com problemas referentes à maternidade, acabam por levantar questões e debates públicos relacionados ao tema da educação do Estado, por exemplo. Penso também que, encarada dessa forma, a maternidade pode levar a demandas por leis ou projetos que sejam especificamente vinculados ao bem-estar e melhoria de vida das mães. Dessa forma, passa-se a entender o papel central das mães na criação, educação e formação de novos cidadãos, pessoas que se relacionam e convivem no espaço público.

A maternidade social elabora demandas e propostas, interpelando ao poder de diversas maneiras, seja por ampliação e qualidade dos serviços, seja pelos direitos a uma vida sexual e procriativa plena, ao trabalho ou contra a violência sexual e os exercícios abusivos de poder. (GABA, 2007, p. 212). ${ }^{33}$

Percebo falas das entrevistadas que perpassam esse segundo sentido de interpretação, o que leva a acreditar em mudanças sociais possíveis, de empoderamento para as mães:

- Mas quando você fala em educação, você pensa em quê?

- Igual eu te falei, respeito, não é? Se eu falar para ele que ele tem que me respeitar, não só a mim, mas também com as outras pessoas - até porque a criança está crescendo, se desenvolvendo, não para ficar o tempo todo do lado dos pais, ele vai ficar no mundo, então além dele respeitar dentro de

\footnotetext{
32 PATERMAN, 1991 apud GABA, GABA, Susana B. (Org.) Diccionario de estudios de género y feminismos. Buenos Aires: Editora Biblos, 2007, p. 211.

33 Tradução livre da autora, do original: "La maternidad social elabora demandas y propuestas, interpelando al poder de diversas maneras, sea por ampliación y calidad de los servicios, sea por los derechos a una vida sexual y procreativa plena, al trabajo o contra la violencia sexual y los ejercícios abusivos de poder." (GABA, 2007, p. 212).
} 
casa, ele tem que respeitar fora também, tem que ter todos os limites (Thaís, 28).

- E quando você pensa na sua relação com sua mãe, você consegue associar as mesmas palavras ou é diferente?

- Mais ou menos porque, assim, eu vejo a minha criando uma mulher, então algumas coisas que ela me ensinou... ela me ensinou a me defender de determinadas práticas, por exemplo, e são essas coisas que eu vou ensinar o meu filho a não fazer. Eu acho que é meio um contraponto, assim, mas eu vejo, eu me inspiro muito nela, ela é muito dedicada e ela é muito direta também, ela é aquela mulher assim, o papo é reto. Ela é carinhosa, é amiga, companheira, mas ela sempre fala as coisas de uma maneira clara, de uma maneira direta, eu tenho que fazer isso com meu filho também. (Priscila, 36).

A primeira entrevistada, Thaís, aponta o respeito e a educação como noções e valores que estão para além da ideia de núcleo familiar e abrengem vivências sociais. A segunda, Priscila, fala da diferença entre a criação de um menino e de uma menina no âmbito da sociedade.

\subsubsection{Compartilhamento entre selves em processos de nomeação}

Essas novas acepções de identificação e de reconfiguração de si por um viés para além do binarismo homem-mulher são formuladas, como disse, pelas entradas de novos textos na semiosfera brasileira. Um representamen novo ao entrar em contato com um objeto desse espaço sígnico cria um interpretante. Esse interpretante é capaz de formar uma relação triádica com outro objeto gerando um novo interpretante, e assim sucessivamente, em cadeias que acontecem concomitantemente, a todo momento, nos selves. E o caráter da primeiridade - como a categoria da imaginação livre de relações definidas, do jogo de ideias só pelo jogo, das qualidades absolutas que ainda não têm residência fixa - é uma evidência legitima do sinequismo, da continuidade que as coisas do mundo têm entre si.

Para Peirce (MS 886 apud COLAPIETRO, 2014, p. 140), um sinequista nunca diz "eu sou todo eu mesmo e em absoluto você", pois, se aceita o sinequismo, os vizinhos e outras pessoas são, de certa maneira, ele também. "Realmente a identidade que você quer atribuir a si mesmo é em grande medida o mais vulgar engano da vaidade”. E existe outra direção pela qual deve ser ampliada a bárbara concepção de identidade pessoal ${ }^{34}$, pois a comunicação que ocorre entre mentes é fruto da continuidade do ser.

\footnotetext{
${ }^{34}$ Peirce, em MS 866, diz o seguinte: "Un himno brahmán empieza de la siguiente manera: 'Yo soy ese Yo puro e infinito, que es dichoso, eterno, evidente, que se extiende por todo y que es el sustrato de todo lo que posee nombre y forma'. Esto expresa, más que humillación, la total disolución del pobre yo individual en el espíritu de
} 
O sinequismo, indo ainda mais longe, reconhece que a consciência do próprio corpo (de sua substância e individualidade) é apenas uma pequena parte do ser humano. Através da consciência social, o espírito ${ }^{35}$ do homem se incorpora a outros, é por onde o ser se mantém muito mais longe do que possa crer observações mais superficiais - por isso também a criação natural do binarismo feminino e masculino pelo corpo biológico e suas consequências nas constituições de identidades possíveis ser algo a ser questionado.

Partindo, então, do pressuposto de que o self em momento algum está isolado, podese dizer que os eventos são lembrados entre as pessoas e que "não é preciso que outros estejam presentes materialmente distintos de nós, porque sempre levamos conosco e em nós certa quantidade de pessoas que não se confundem.” (HALBWACHS, 2006, p. 30).

O descentramento do sujeito significa a centralidade das práticas em sua materialidade, pluralidade, historicidade e, portanto, mutabilidade. Consciência, engenhosidade, criatividade e outras características, que atribuímos a agentes criativos, são sempre funções de sua constituição cultural e localização histórica. Os sujeitos agem, portanto, em meio à multiplicidade de interações e diálogos. (SALLES, 2014, p. 16)

Por isso falo em uma semiosfera brasileira, em que as memórias são organizadas e os signos se interconectam em um continum de textos, códigos e linguagens, que configuram sentidos. E dentro dessa semiosfera existem outras tantas, existem todos os selves que compartilham de sua memória. Selves que compartilham das referências e significações de outros países também e que comunicam memórias entre si. Portanto, as vivências das mães são situadas historicamente no tempo e no espaço. Suas experiências e as vivências que aparecem em suas falas são possíveis por conta do momento histórico em que habitam.

Pensando nessa comunicação entre selves, não se pode perder de vista que as possibilidades de compartilhamento de memórias não vinculam a destruição da unicidade do ser. O self é algo único e irredutível, e o que ele é em si mesmo somente é revelado, ou percebido, através de suas relações com outros - outros que não precisam necessariamente estar presentes, que podem nem mesmo existir. Peirce escreveu principalmente para aqueles que vieram depois dele. (COLAPIETRO, 2014, p.121-122).

\footnotetext{
la oración.” (tradução espanhola de Marta Revuelta de 2001). O hino, segundo o MS S70: 7, é do princípio de La metafísica de los Upanishads, ou Vichar Sagar, uma obra de Niscaladasa (1863), titulada originalmente Vicarasagara; traduzida por Lala Sreeram (1885).

${ }^{35}$ Nessa mesma tradução, Peirce afirma: "Creo que he dicho lo suficiente como para mostrar que, aunque el sinejismo no es una religión, al contrario, es una filosofía puramente científica, podría llegar a aceptarse con carácter general que, como confiadamente anticipé, puede jugar un papel en la reconciliación entre religión y ciencia." (MS 866, tradução espanhola de Marta Revuelta de 2001).
} 
Pensando nessas relações históricas que acontecem no tempo e espaço, pergunto às mães se elas se acham parecidas com outras, isto para entender como elas percebem os possíveis hábitos. Isto sabendo que as respostas estão situadas no tempo-espaço, ou seja, que são o que as entrevistadas recordaram naqueles momentos específicos e trouxeram para o centro da semiosfera como descrição de semelhanças e diferenças:

- Acho que sim. A maioria das mães acaba tendo alguma coisa em comum, não sei o que. Talvez [silêncio]. Ah.. não sei porque as mães são bem diferentes, né? Algumas vezes eu vou parecer com umas, outras eu vou parecer com outras. Tipo, algumas mães são mais dedicadas, nessas eu posso me incluir. Mas isso vai ser bem relativo também, ne, eu acho. Por que é como se tivessem vários níveis. Por exemplo, responsabilidade, dedicação, amorosidade, ou respeito, sei lá... várias coisas. E aí cada mulher vai tendo uma porcentagem. Em algumas eu to mais, noutras, to menos, tipo, paciência é uma coisa que eu não tenho muita, que outras mães vão ter mais que eu. (Clara, 30).

- Eu conheço dois extremos assim, as mães que são mais próximas de mim, dois extremos, algumas que levam os filhos pequenos para bares e para restaurantes e para shows na rua e aquela coisa assim que foi um sacrifício para meu filho e outras mães que também abdicaram de tudo para se dedicar exclusivamente aos filhos, o que eu também acho uma situação muito estranha, as vezes eu me sinto meio no meio, assim, sabe, eu abdiquei de algumas coisas mas, também fiz questão de tocar minha vida em outros aspectos, estou tentando equilibrar assim, quem eu sou e a que eu preciso ser, a mãe. (Fátima, 36).

- Ah... acho que são todas iguais. As mães são tipo heroínas, eu acho. Assim, elas podem não ter nada que elas tão atrás de fazer tudo pelo filho e de certa forma elas conseguem. Cada uma do seu jeito, cada uma vai conseguindo. As mães são heroínas, eu acho. Todas, a minha também. (Vânia, 57).

Nesta investigação, os sujeitos são os principais atores para o entendimento dos hábitos referentes à nomeação da mãe. Resgato nas narrativas os processos comunicacionais de formação de sentido que, ao trazerem à tona representações sociais, constroem a experiência da maternidade e sua diversidade. Os sujeitos não são, no entanto, as únicas fontes, pois para dar forma ao social coletivo-individual é necessário trazer outros elementos presentes na cultura: fotos, filmes, novelas, livros, revistas, músicas, etc. As lembranças dos próprios sujeitos também fazem referência a esses outros materiais. Os relatos vão dando forma ao que está sendo nomeado. E o reconhecimento das coisas pelo seu nome é o reconhecimento de nós mesmos.

A nomeação, a partir da compreensão do pragmaticismo e seu sentido de clareza, como desenvolvi no segundo capítulo deste texto, permite que se entenda que para saber o 
nome tem-se que indagar e chegar a saber seu nome. "Son esferas de reconocimientos diferentes, una cosa es informarnos sobre «su nombre» y otra, comprender «su nombre». Es justamente en este último que se da el proceso de reconocernos a nosotros mismos." (RUSSI, 2016, p. 169).

Há, portanto, um sentido ético que traspassa a breve frase. Isto é, compreender, ter sapiência do que nomeio, implica que minhas decisões estejam adequadas a esse conhecimento. Assim, «a mente não está sujeita a 'lei' no mesmo sentido rígido em que o está a matéria. (...) Sempre permanece uma certa quantidade de espontaneidade arbitrária em sua ação, sem a qual estaria morta» [CP6.148, 1891]. Desta maneira, nomear é reconhecermos a nós mesmos, nas espontaneidades e tonalidades de como nomeamos, iss fala de nossa obrigação ética de saber o que nos sucede; é dizer, nomeamos e nos nomeamos - a rigor, nos fazemos em nossos atos-. (RUSSI, 2016, p. 169). ${ }^{36}$

Russi (2016) faz longa explanação sobre uma frase de Nubiola, pensador da obra de Peirce e de D’Ors: “...del lenguaje esencial que nos permite reconocer las cosas y reconocernos a nosotros mismos al decir las cosas por su nombre." ${ }^{37}$. Primeiro, enfatiza dois conceitos "reconocer" e "esencial", que, em sua interpretação, se tornam centrais para compreender a ação que sustenta a frase.

Por “reconocer", Russi (2016, p. 170) destaca a qualidade de palíndromo, qualidade que se mostra em uma figura circular. Recorre, também, a definições de um dicionário geral etimológico. Reconhecer demanda um reconhecedor que examina alguma coisa ou pessoa para se inteirar de sua identidade, natureza ou circunstâncias. É examinar todos os seus lado e aspectos para compreendê-la ou retificar um juízo anteriormente dado sobre ela e, também, distingui-la das demais.

Com relação à “esencia”, Russi (2016, p. 172) qualifica como algo que é por sua mesma virtude o ser e a natureza das coisas, caráter radical e profundo. "Cosas por su nombre” é a essência que nos configura como seres em ação. Como cada pensamento é um

\footnotetext{
${ }^{36}$ Tradução livre da autora, do original: "Hay, por lo tanto, un sentido ético que traspasa la breve frase. Es decir, comprender, tener sapiencia de lo que nombro, implica que mis decisiones estén adecuadas a ese conocimiento. Así, «la mente no está sujeta a 'ley’ en el mismo sentido rígido en que lo está la materia. (...) Siempre permanece una cierta cantidad de espontaneidad arbitraria en su acción, sin la cual estaría muerta» [CP6.148, 1891]. De esta manera, nombrar es reconocernos a nosotros mismos, en las espontaneidades y tonalidades de cómo nombramos, eso habla de nuestra obligación ética de saber lo que nos sucede; es decir, nombramos y nos nombramos - a rigor, nos hacemos en nuestros actos-." (RUSSI, 2016, p. 169).

${ }^{37}$ NUBIOLA, J. El compromisso esencialista de la lógica modal, estudio de Quine y Kripke. Pamplona, EUNSA, 1991. In: RUSSI, 2016, p. 167.
} 
signo e a vida é uma sucessão de pensamentos, o ser humano é um signo (CP. 5.314, 1868) por isso, self.

\subsection{A passagem do tempo e as transformações na memória}

A nomeação também vai se modificando com o tempo, conforme a expansão do self em encadeamentos e organizações das ideias. Os selves, nos percursos das mães, adquirem formas flexíveis, móveis. A consciência do processo como elemento da cognição aparece na forma de aprendizado, de aquisição de desenvolvimento mental. Esse tipo de consciência não pode ser imediato porque cobre certo período do tempo, continuando através de cada instante, não podendo ser contraído para caber em um único momento.

Tal consciência é a responsável por unir os eventos de nossa vida em um ato de síntese. Aquilo que existe apenas como instante presente, completamente separado do passado e do futuro, é algo um tanto obscuro, sem possibilidade de ação e, portanto, de binariedade aqui no sentido de binaridade entre ação e reação em trabalho e jogo (d'ORS, 1998).

O sentimento do momento presente, obscuro, não poderia referir-se de fato a nenhum "eu", nem mesmo nitidez nesse sentir seria encontrada sem a continuidade das partes e a função da síntese. Portanto, apesar de a primeira categoria permitir que acontecimentos inesperados ou sem razão de ser realmente ocorram, a consciência da síntese desses eventos e de outros no tempo é atributo da terceridade. O ser voltado para o futuro aparece em formas mentais, intenções e expectativas. A memória retoma o passado através de uma espécie de força bruta, uma ação binária.

- Agora, quando você pensa na palavra mãe, o que vem a sua mente?

- Na minha mente, vem cuidado. A gente aprende a cuidar do outro. Pra mim, foi muito mais forte ainda, porque eu pensava que eu não sabia cuidar de nada. Eu tinha uma vida muito livre, entende? E aí eu me deparei com meu primeiro filho, que tem 28 anos, especial. Ai é que eu fui começar a botar meu pé no chão e via que eu precisava cuidar dele. Levava ele pra fazer tratamento, levei, passei a cuidar dele. Sabe, eu fiz isso como um objetivo da minha vida. Ele não andava, eu falei "eu quero que ele ande, eu vou cuidar dele". Então pra mim é o cuidado, que a gente aprende, a cuidar do outro. (Camila, 54).

Portanto, a maturação, a consciência da síntese traz a noção de que ser mãe tem a ver com cuidado, pois foi pela maternidade que se aprendeu a cuidar do outro.

A respeito da memória, Peirce tem uma passagem que diz que temos uma cognição que declara reproduzir as sensações advindas da primeiridade, contudo, segundo ele (2010, p. 
15), não existe semelhança alguma entre a memória e as sensações porque nada se assemelha ao sentimento imediato. "A semelhança pressupõe um desmembramento e recomposição que são totalmente estranhos ao imediato" (ibid.).

Olhe para uma superfície vermelha e tente sentir a sensação correspondente, e a seguir feche os olhos e recorde-a. Não há dúvida de que pessoas diferentes se manifestam diferentemente sobre isto: para algumas, a experiência parecerá produzir um resultado oposto, mas eu me convenci de que nada há em minha memória que seja, ainda que minimamente, tal como a visão do vermelho. Quando o vermelho não está diante de meus olhos, não consigo vê-lo de modo algum. (PEIRCE, 2010, p. 15).

Da mesma forma como não se pode rememorar com precisão uma cor, não se pode recordar com total minúcia de detalhes as sensações de quando se vê um(a) filho(a), pois são dados do imediato que se perdem com o tempo, porque a memória é articulada com as experiências que se sucedem. Quando se traduz ao rememorar, traz-se o passado por meio de novos códigos. O imediato se esvai com o tempo nesse processo de transfiguração. $\mathrm{O}$ imediato aparece em uma relação icônica, ou seja, de qualidade. Mas a relação entre mãe e filho não se estabelece no imediato, mas nos representamens que vão aparecendo com o tempo. Gostaria de trazer para esta discussão a divisão dos signos de Peirce. A mais importante divisão dos signos faz-se em ícones, índices e símbolos.
Embora nenhum representamen realmente funcione como tal até realmente
determinar um interpretante, torna-se um representamen tão logo seja
plenamente capaz de assim proceder; e sua qualidade representativa não
depende necessariamente de ele alguma vez realmente determinar um
interpretante, nem de ele alguma vez ter realmente um objeto. (PEIRCE,
2015, p. 64).

O representamen se divide por tricotomia em símbolo, índice e ícone. Um ícone é um representamen que cumpre essa função em virtude da qualidade que tem com alguma coisa sua qualidade representativa é a primeiridade. ${ }^{38} \mathrm{Um}$ signo por primeiridade é uma imagem de seu objeto, ele é uma ideia que produz uma ideia interpretante. O objeto externo excita tal ideia através de uma reação sobre o cérebro.

Um índice é um representamen que cumpre tal função em virtude da qualidade que ele não poderia ter se o seu objeto não existisse, mas que continuaria a ter se ele fosse interpretado como um representamen ou não. Um exemplo que Peirce (CP 5.73) traz é um higrômetro à moda antiga, que é um índice feito de modo a ter uma reação física de acordo

\footnotetext{
${ }^{38}$ Ver o primeiro capítulo desta dissertação, p. 36.
} 
com a umidade do ar. Sua reação continua ocorrendo mesmo que o instrumento seja esquecido inteiramente, ou seja, mesmo que a transmissão de informação cesse. Portanto, a forma específica que se cuida de um(a) filho(a), o modo como lhe fazer carinho, lhe dar atenção, lhe preparar comida. Esses representamens aparecem em virtude da qualidade que eles não poderiam ter se o filho não existisse, mas é interessante notar que não costumamos interpretar esses representamens indiciais e mesmo assim eles continuam a ter suas qualidades.

Um símbolo é um representamen que cumpre sua função independentemente de qualquer semelhança ou analogia com seu objeto. Sua função também é independente de qualquer relação factual, ela acontece única e simplesmente porque ele é interpretado como um representamen. Exemplos de símbolo são a palavra, a sentença e o livro.

Por meio desses representamens, a memória materna vai sendo construída. Antes do presente da entrevista, por exemplo, existe todo um percurso de vida. E o afloramento do passado se revela em palavras, gestos, expressões, corpo. Mesmo sem os dados do imediato, a memória permite a relação do corpo presente com o passado e, além do mais, é determinante para o curso atual das representações. A consciência que une os momentos de nossa vida vai sendo mostrada com o tempo (em sentido cronológico, que passa) constituída instante por instante, unindo memórias de momentos diferentes e sintetizando.

Nessa síntese, a diferenciação entre memória e lembranças ${ }^{39}$ não fica clara para a mente. Mas o vínculo com o passado, que garante a continuidade temporal de uma pessoa e sua identidade, sem ruptura com o presente, é premente, embora esse vínculo não seja tratado como posse de um sujeito, mas como memória compartilhada entre selves ${ }^{40}$.

As memórias estão ancoradas em teias de lembranças em que confluem pensamentos de origens diversas, que provêm de tempos distintos (em sentido cronológico, de convenção

\footnotetext{
39 Tomando como base os estudos da tradição do olhar interior - que remonta Platão e Aristóteles, passa por Santo Agostinho e chega a John Locke e Husserl -, a memória é diferenciada das lembranças - no plural. De um lado, a memória continua sendo a capacidade de voltar no tempo e prosseguir até o presente, em um ato contínuo, sem rupturas temporais. Por outro lado, as lembranças são vistas como distribuídas e organizadas em níveis de sentido, "em arquipélagos, eventualmente separados por abismos" (RICOEUR, 2007, p. 108). Uma representa a continuidade da experiência e da pessoa, e as outras, a diferenciação e a separação.

${ }^{40}$ Maurice Halbwachs inicia a atribuição da memória diretamente a uma entidade coletiva, chamada por ele de grupo ou sociedade em A Memória coletiva. Para rememorar, a partir desse texto, precisa-se dos outros: a memória coletiva não pode ser vista como derivada da privada. $\mathrm{O}$ viés de seus estudos difere das pesquisas de Bergson, em que o método introspectivo conduz à reflexão sobre a memória como subjetividade livre e conservação espiritual do passado, sem levar em consideração quadros social ou cultural. Halbwachs (2003) relativiza o princípio de Bergson pelo qual o espírito conserva em si o passado na sua inteireza e autonomia, para ele nos lembramos porque os outros e a situação presente, nos fazem lembrar. Entretanto, a concepção de que nos lembramos pelo social, apesar de interessante, não é suficiente para esta análise, pois com o conceito de self não existe um sujeito primordial que se lembra: o social ou o individual. Existem relações entre selves que formam sentidos na memória.
} 
social), que sempre estão ligados ao tempo simbólico. Algo da memória de um self mãe aparece pela retomada das lembranças a partir de outros pensamentos que ela tenha contato em outros momentos e que compõem o todo de sua memória.

- E quando você pensa no inicio da sua primeira gravidez, da gravidez que vingou, até hoje, o que mudou na ideia de mãe? Você acha que pensa a mesma coisa sobre esse conceito? Naquela época, você acha que já pensava em cuidado?

- Não. Eu fui adquirindo isso com as circunstancias, com os aperreio que eu passava, sabe? Na tora. Como cuidar de uma criança especial? Como cuidar de uma criança, toda criança é especial, né, como cuidar de uma pessoa, de um ser humano, né, para ele ser um, né, para ele viver.

- Agora, você consegue entender como é que é esse processo de modificação pelo que você passou?

- Eu consigo entender agora que valeu a pena, mas durante o processo a gente se culpa muito, sabe, a gente não entende até aceitar. No meu caso, eu considero um caso diferenciado porque até eu aceitar que eu tinha um filho especial era um cuidado maior, né? E aí eu fui, me revoltei, neguei, achava que eu não tinha condições de ser mãe. Por quê? Aquela pergunta toda: por quê? Por quê? Por que eu? Por que eu? Você se vê de vítima, né, mas aí depois você vai entendendo. Hoje, com a maturidade, eu já entendo que eu precisava disso pra hoje eu ser a pessoa que eu sou. (Camila, 54).

Tomando, então, a palavra "filho", o ícone é a fotografia mental composta de todos os dias em que se depara com esse filho, que a mãe vivencia. $O$ índice é tudo aquilo pelo que a mãe distingue o filho, tal como se coloca em sua experiência. E o símbolo é o ato mental pelo qual ela assinala essa pessoa como filho, formulando sua relação com ele pela ideia de cuidado. $^{41}$

\subsubsection{As formações de sentido na memória}

Pensando as imagens recordadas das situações entre mãe e filho(a) como signos icônicos. Qualquer uma delas leva outra (seu interpretante) a referir-se a um objeto ao qual ela mesma também faz referência. Por sua vez, o interpretante, de modo idêntico, será transformado também em signo, e assim sucessivamente ad infinitum.

As imagens que aparecem no momento em curso são, portanto, representamens de situações (objetos) de um momento que passou. E elas levam à formação de interpretantes, que, por sua vez, são também signos que levam a formação de novos. Um signo, ou representamen, é o que, sob certo aspecto ou modo, representa algo para alguém. Ao dirigir-se

\footnotetext{
${ }^{41}$ Ver Peirce (2010, p. 115).
} 
a uma pessoa, ele cria na mente um signo equivalente ou, talvez, mais desenvolvido. Ao signo criado, Peirce (2015, p. 46) denomina interpretante do primeiro. O signo representa seu objeto, não em todos os seus aspectos, mas com referência a um tipo de ideia, ou "fundamento do representamen".

A situação passada, ao ser revista, aparece de forma nova graças à espontaneidade da primeiridade. Essa imagem reaparece semelhante à primeira vez, mas com algumas diferenças. As semelhanças qualitativas se dão por uma relação icônica; e as diferenças que se identificam, se dão por relações indiciais que vão sendo estabelecidas com o passar do tempo pelas situações novas que vão surgindo.

Para pensar sobre esse processo de desenvolvimento do signo, trago a composição Las meninas - integrada por 58 pinturas, releituras feitas por Pablo Picasso em 1957 do quadro de Diego Velásquez, pintado em 1656. Ver figuras 5, 6, 7 e 8.

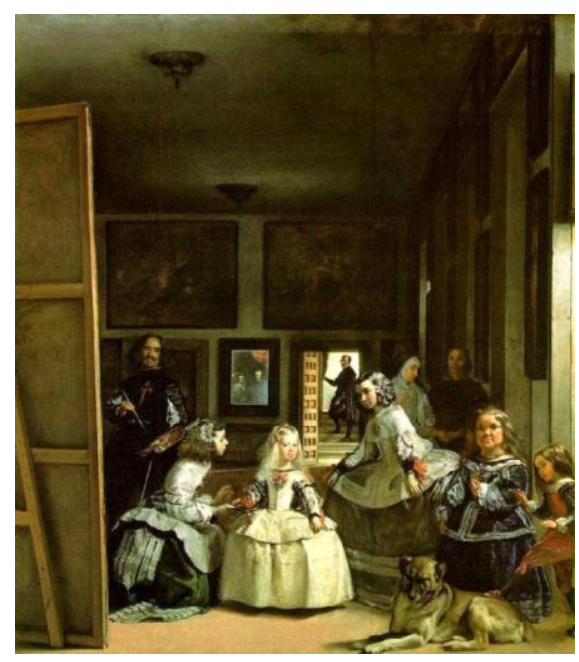

Fig. 5

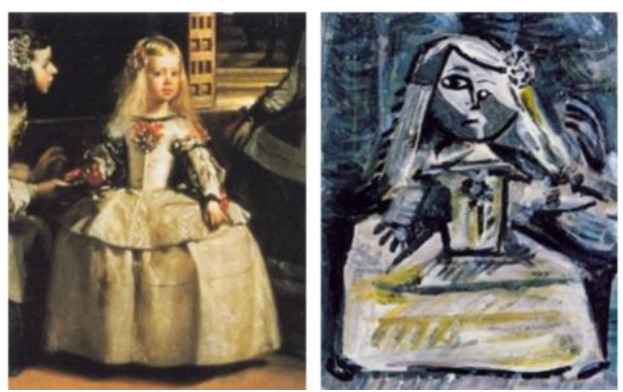

Fig. 7

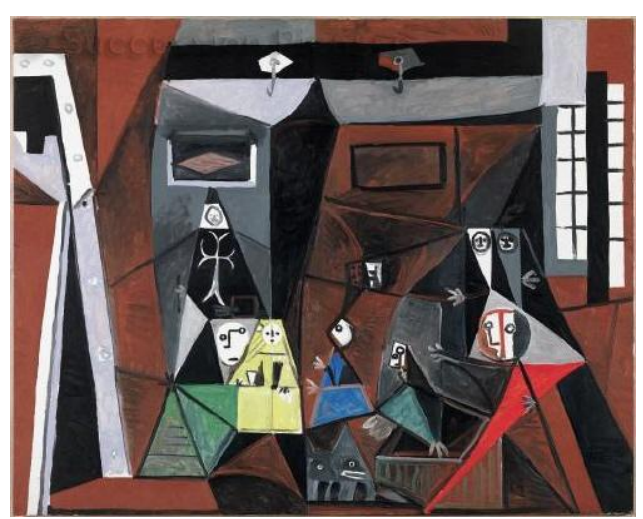

Fig. 6

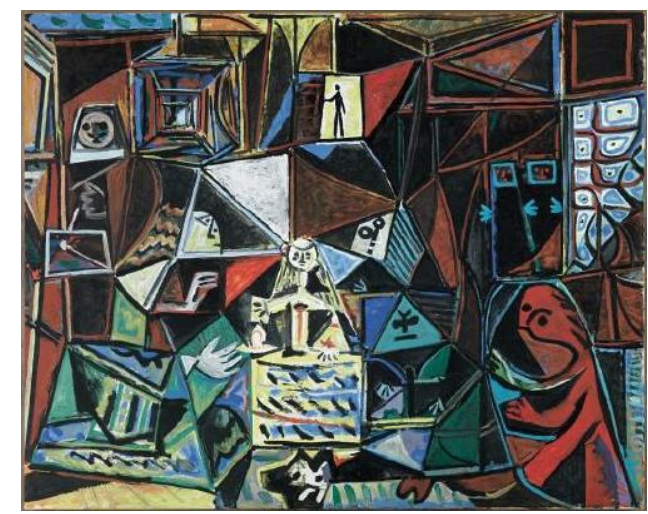

Fig. 8 
Observando tais pinturas, percebe-se a relação icônica premente entre os quadros, que se dá em razão da similaridade qualitativa que possuem entre si e em referência à pintura de Velásquez: a maneira como os elementos foram dispostos, a marcação dos traços nos vestidos e cabelos, as formas. Apesar disso, as diversidades entre as pinturas trazem uma oposição possível apenas pela qualidade da secundidade, em uma relação indicial - é como se existisse uma contiguidade de um rio que percorre todos eles em um mar de diferenças.

Pensei nessas imagens, de forma imaginativa, como se fossem memórias de uma mesma pintura, que acontecem no self em momentos diferentes. Pode-se pensar nas figuras como retomadas feitas pelo próprio movimento da mente em momentos cronológicos diferentes. A cada nova retomada, novas formas a imagem adquire. Essas modificações são possíveis a partir do entendimento de que novas relações são feitas da pintura com textos que submergem o mesmo espaço abstrato sígnico. Isto tomando a memória como um espaço semiótico - a semiosfera - em que os elementos, que chegam pela fronteira, aos poucos vão tomando espaço e modificando os códigos e linguagens do espaço inteiro ${ }^{42}$.

Assim, a fronteira com um texto estrangeiro sempre é um domínio de intensas formações de sentido. Por outro lado, todo pedaço de uma estrutura semiótica ou todo texto separadamente possui os mecanismos de reconstrução de todo o sistema. A destruição dessa totalidade provoca um processo acelerado de reconstrução do todo semiótico por uma parte dele. Essa reconstrução de uma linguagem perdida sempre resulta na criação de uma nova e não na recriação da velha.

Nessa reconstituição, o esquecimento é fundamental, ou não seria possível que memórias fossem criadas a partir de outras. É somente quando se esquece algumas experiências de maternidade que se possibilita que outras venham a adquirir sentido na formação e reconstrução constante do conceito de mãe. "E há também magia naquela outra

\footnotetext{
${ }^{42}$ Nesse sentido, a memória, em constante modificação, não poderia se referir à metáfora que compara a escrita interior - a impressão das imagens na memória - à escrita em uma tábua de cera, que é sugerida pelo uso, na antiguidade clássica, da cera para escrever. Para Aristóteles, todo conhecimento depende de impressões sensoriais; elas são, portanto, sua fonte básica. Platão também se utiliza da metáfora da impressão do selo em passagem do Teeteto, em que Sócrates propõe que há um bloco de cera em nossas almas - de diferentes qualidades, de acordo com os indivíduos - e diz que ela é "o dom da Memória, a mãe das Musas" (191, C-D in YATES, 2007, p. 57). Conforme Platão, quando vemos, escutamos ou pensamos, a cera é submetida às percepções e aos pensamentos, que são impressos nela, assim como imprimimos as formas com carimbos. No entanto, diferente de Aristóteles, Platão acreditava que existia - latente em nossa memória - um conhecimento não derivado das impressões sensoriais, mas das formas e moldes das ideias e realidades que a alma conheceu antes de descer à Terra. Em Fédon (p. $75^{\text {B-D }}$ in YATES, 2007, p. 57) ele desenvolve o argumento de que todos os objetos sensíveis estão relacionados a determinados tipos, dos quais são meras aparências. Esses tipos foram vistos por nós antes de nossa vida aqui embaixo ter se iniciado, portanto estão em nossas memórias ao nascermos.
} 
nobre arte, a do esquecimento, sem a qual o próprio Borges afirmava que é impossível pensar." (IZQUIERDO, 2002, p. 18) - retomando o conto de Borges, mencionado no título Pragmaticismo desta dissertação Funes el memorioso (BORGES, 2015, p. 133).

O pensamento esquece diferenças, generaliza, abstrai. Nos relatos das mães entrevistadas, ao falarem de algum momento vivido, elas não se atêm a detalhes das conversas, de todas as palavras mencionadas, da disposição de todos os objetos presentes na cena. Também não conseguem recordar cada sentimento que tiveram no decorrer do acontecimento.

Apesar das limitações que existem no próprio ato de transpor em linguagem o que se pensa e sente, e apesar de não darmos conta de transpor em palavras os vários caminhos que a memória apresenta, esta dissertação - caminhando para suas considerações finais - traz propostas de análise deste algo imaterial e mutável que é a memória. Ao mesmo tempo, penso que um momento fugidio, que pode se perder no tempo, se transfigura e se apresenta vivo no instante em que é recordado e falado. Acredito também que, ao colocá-lo no papel em uma proposta de análise, tenta-se, de algum modo, reconfigurá-lo e apreendê-lo. Apreensão no sentido da possibilidade de modificar a semiosfera de outros selves que tenham contato com este texto. 


\section{CONSIDERAÇÕES FINAIS}

"Vamo simbora, camarada,

Camarada, já é noite Vamo simbora, camarada, Camarada, amiga minha Vamo simbora, camarada, Camarada, amigo meu."

(Corrido de Capoeira Angola)

Finalizo esta dissertação pelo início, como as rodas de capoeira que encerram e recomeçam na sexta-feira seguinte. Cada instante deixa sua memória, mas sabe-se do laço que se cria assim; nas descobertas de cada semana e nas novas possibilidades que se reconhecem no corpo e na mente, percebendo que os dois compõem o self em um continum. Memórias que dialogam entre selves de sextas-feiras em sextas-feiras.

Sei do processo contínuo desta dissertação quando percebo que a cada retomada dela novas bifurcações acontecem pela iniciativa da primeiridade, por isso a dificuldade em parar de escrever, ler e modificar: há sempre aquela potência querendo transformar-se em terceiridade. Mas chega o momento em que se deve parar de transbordar primeiridades e entregar o que já se tem. Deixo aqui o que tenho no momento em registro, a mente ainda não parou, e é provável que nunca pare, ao pensar que não há isolamento possível na comunicação com os outros, outros que virão até depois de nós.

Pois bem, a chama da minha questão-problema começou a tomar contorno com a ideia do que vem a ser comunicação. Éramos alguns amigos conversando sobre um antigo programa de televisão que assistíamos na infância; tentávamos lembrar seu último episódio.

Eu pensava naquela época, dois anos atrás mais ou menos, sobre a comunhão entre as pessoas por conta de memórias em comum. Pensava num isolamento e, em seguida, na comunhão pelas referências culturais comuns; ou seja, na semiosfera comum. Isto sabendo que, para cada self, as interpretações de um mesmo episódio de televisão seriam diferentes, mesmo que houvessem diálogos entre suas semiosferas, em processos de semiose.

Por movimentos de inquirição e pelas formas que vão dando contornos ao mundo a partir da coordenação de ideias, me deparei com uma inscrição que me deixou emocionada. 
Estava no Santuário dos Pajés, onde vivem índios da etnia Fulni-ô, e vi uma frase de um índio que vivia no meio da mata, em um lugar muito isolado. Ele pedia ao pajé Santiê que lhe enviasse alguém, um mensageiro, porque ele já começava a se esquecer de tudo, já não sabia se conseguia até mesmo falar. A mensagem me intrigou porque nos constituímos enquanto selves pela relação com o mundo e com os outros selves.

Meu interesse em estudar as formações de sentido a partir da semiótica na área de comunicação social surge porque eu buscava entender como nos constituímos por meio da linguagem, que é um ato social. Nos comunicamos pela linguagem e dela provêm memórias comuns. Iniciei a pesquisa, portanto, tentando entender o sentimento de estar até certo ponto isolado e entrar em comunhão pelo ato de comunicar.

O que eu buscava entender, portanto, era a constituição do self a partir de formações de sentido que se dão pela linguagem, pensando que o ser humano se utiliza da palavra para se comunicar, minha ideia era compreender como esse processo de constituição se dá a partir da nomeação das coisas. Isto pensando que ao nomearmos as coisas do mundo estamos também nomeando a nós mesmos.

No decorrer da dissetação trabalhei, portanto, a categoria isolamento-comunhão, penso na ideia de que existe o contato constante entre os selves nas formações de sentido na memória, como espaço abstrato e não depositório de significados. Essa categoria foi importante para análise porque me fez perceber experiências das mães que passam pelo singular e pelo plural. Me fez pensar ainda que essas experiências são expressões que constroem histórias de vida particulares e sociais. E que o particular nunca se dissocia do social.

Com essas ideias, a princípio, pensei em partir do conceito de Memória coletiva de Halbwachs (2003), mas ele se mostrou insuficiente porque tratava-se de grupos em que o indivíduo está inserido. E neles para a constituir memórias coletivas. Além disso, para o autor, somento nos lembramos dos eventos com o contato com os outros. Nesta análise, isso não se aplica porque não existe um sujeito primordial que recorda na relação entre selves.

De lá para cá, os questionamentos com relação às formações de sentido na constituição do self cresceram. Mas eu precisava de um mote que desse conta das possíveis experimentações que queria fazer para compreender as formações de sentido na memória. $\mathrm{O}$ que era para ser apenas um mote, no entanto, veio como uma inquietação política, algo que me fez agir e que motivou meu coração a continuar a pesquisa. Ele passou a me instigar porque percebi experiências de mulheres que desejavam muito ter filhos e que, ao realizarem esse sonho, se sentiram muito tristes. Eu me questionava sobre o por quê disso acontecer. 
Fiquei pensando em como as mulheres se reposicionam no mundo, a partir do que elas compreendem pelo conceito de mãe, pelo que elas nomeiam como o que é ser mãe, quando se deparam com a experiência da maternidade. Minha questão problema foi, portanto, “como o self mãe cria forma?"

Minha aproximação do tema da maternidade não é uma aproximação fácil porque eu nunca tinha me debruçado sobre ele de forma mais detida e também não sou mãe. O que eu tentei na dissertação foi encontrar o sentido da palavra "mãe" a partir de referências encontradas na cultura brasileira, em especial. Por isso trago algumas imagens de pinturas, me remeto a cenas de novela, capto falas encontradas no cotidiano e trago entrevistas. Tento, por meio desses elementos da cultura, experimentar clarear o conceito de "mãe" trabalhando com o pragmaticismo de Peirce, que é o método de clareamento das ideias. Apesar dos outros elementos culturais, para esta dissertação, os sujeitos foram as principais fontes para o clarear do conceito "mãe", no caso, as mulheres entrevistadas.

Esse defrontar com pessoas que vivem a situação me fez pensar a relação mãe-filho desde outro ângulo, não como uma dessas mães, mas como pesquisadora que busca escutar o que dizem do mundo. Alguns hábitos possíveis foram se apresentando, como completudeincompletude, a ideia de heroínas, a ideia da doação. Digo que esses são hábitos possíveis porque, como já mencionei durante o texto, não retiro respostas conclusivas das entrevistas. Busco com elas, experimentar relações entre as falas, as imagens, as cenas de novela, a figura da ex-presidenta Dilma. Assimilo essas referências e procuro trabalha-las a partir do meu referencial terórico.

Minha questão permeia o feminismo e entra nos valores sociais que se impõem à mulher. Eu acredito que as noções de hierarquia e poder colocadas neste texto não são exagero. Percebo essas diferenças hierárquicas nas falas das pessoas, nas formas como nomeiam e agem conforme o nome que dão. Eu sei que esse tema é muito rico e pode bifurcar-se por caminhos diversos. Essa discussão nem começa nem termina aqui. O que produzo é mais um representamen capaz de, na relação com o objeto, gerar interpretante.

Eu trabalho na pesquisa a partir do viés feminista, focando na história cultural, que questiona a história humana na forma como a gente compreende, questionando ideologias e valores que estão submersos nessa forma de contar nossa história. Tive contato com alguns textos de teorias feministas por conta de uma disciplina que fiz na história com a professora Susane Rodrigues de Oliveira. Nessa perspectiva, eu interpreto os hábitos vigentes na sociedade com o questionamento feminista. Colocando em cheque inclusive a noção binária de separação entre sexos e gêneros, que ocupa posição central na formação da identidade da 
pessoa. E esse binarismo está muito vinculado ao corpo. O corpo da mulher passaria então de um corpo sedutor ao corpo de gravidez, que está atrelado a um papel social ainda muito focado na procriação.

Minha dissertação é um modo de ver as coisas que se apresentam no mundo desde outro viés. A semiótica de Peirce permite entender as transformações das ideias e formações de sentido de modo mais minucioso, com imagens e percepções até então não pensadas por mim. Nesse ínterim, os processos de compreensão dos índices, símbolos e ícones que estão à disposição na cultura para apreensões de semiose passam a ser interpretados de modo diferente por mim. O quadrado semiótico e a semiosfera vêm para reforçar estas novas percepções que se formam em minha mente.

Enquanto escrevo estas considerações finais percebo o quanto mudei de dois anos para cá. Recordo aquela ocasião em que buscava na memória o episódio do programa. Cada pessoa dava uma dica, um palpite, e construíamos juntos a narrativa. Agora deixo que aquele momento (ou este, pois já está aqui na minha mente) venha novamente. As ideias de lá para cá encadearam de tal forma que já pareço outra pessoa - e isso em um curto espaço de tempo. No entanto, como indivíduo, que dura mais que um instante pela continuidade de suas ações, eu consigo perceber a sensação de ininterrupção que minha memória propicia.

Enfim, nos últimos dois anos, o processo do mestrado foi determinante para alguns pensamentos que formulei. Eu permiti, inclusive, que minhas reflexões a partir do pensamento de Peirce saíssem do âmbito da academia e me ajudassem a resolver questões minhas. Por exemplo, deixei que alguns acontecimentos que me fizeram mal simplesmente contribuísse para o desenvolvimento deste signo que é o self; permiti, então, observar como as ideias foram sendo encadeadas para culminarem em certos acontecimentos que não gostei de ter vivido. Fiquei ainda a reparar e tentar encontrar alguma ideia anterior que já anunciasse o que viria depois. E me deixei perceber, também, como as ideias vão me levando a outros caminhos possíveis e me afastando cada vez mais daquilo que foi ruim.

Essa permissão que eu me dei foi a partir do que eu estava nomeando, de como eu estava entendendo o processo de mestrado. Eu pensei que seria interessante traçar por esse caminho a partir do entendimento do pragmaticismo. Como eu poderia tornar clara uma ideia se eu não me aproximasse dela com uma dúvida que perpassasse o coração? Como eu poderia entender os processos de formação de sentido no self mãe se eu não conseguisse entender nem mesmo meus processos íntimos a partir do que eu lia, os processos do self? Por conta de seguir um caminho trilhado pela ética, eu sabia que a nomeação que eu desse ao mestrado e à minha dissertação teria que dialogar intimamento com o pragmaticismo. Isto pensando que a 
busca de respostas para uma dúvida genuína não pode ser pela via de considerar o objeto como externo a mim, se estamos conectados conforme o sinequismo. A partir desse entendimento, eu poderia retirar inferências e formular opinião.

Minha dificuldade, no entanto, em concatenar as ideias em possíveis caminhos trilhados pela questão-problema a fim de estabelecer opinião é algo que perdurou todo o processo. E essa dificuldade perturba porque ela nega o pragmaticismo e o sinequismo. Esse foi com certeza o maior desafio. Apesar de o intuito com esta dissertação não ser chegar a resoluções e conclusões, mas discutir e percorrer alguns pensamentos a partir de uma questãoproblema trabalhada por meio do referêncial teórico e metodológico escolhidos, considero de suma importância que as ideias estejam concatenadas de forma clara e alcancem alguma formulação de crença.

No processo de inquirição e busca pela opinião, percebia como o pensamento vai se organizando de tal forma que ora estabelece certas dúvidas para estarem no centro da semiosfera e ora consegue se transformar para transladar ao centro dúvidas que ainda não eram claras no momento anterior. Fico pensando se as dúvidas que foram sendo levadas ao centro no momento posterior já não estavam como pensamento latente, embora à margem, no momento anterior, e foram se unindo a outras ideias até atingirem o centro.

De qualquer forma, as possíveis dúvidas que estavam à margem, às vezes só como primeiridade, ao chegarem ao centro e converterem-se em terceiridade - ou seja, ao serem reconhecidas de fato como algo inteligível - já são em verdade outra coisa. Uniram-se de tal forma a outras ideias que já são coisa diferente do que eram na etapa que veio antes, embora tragam algo de qualidade da etapa anterior.

Falar de maternidade seguindo o caminho metodológico do pragmaticismo me permitiu trazer falas de mães e reconhecer as particularidades de cada uma e, sobretudo, os hábitos. O pragmaticismo me propiciou ir à busca de concepções de cada um, ir à busca do que as pessoas pensam sobre o assunto, do que existe sobre o assunto na cultura, daquilo que se transforma e do que permanece. O pragmaticismo me incentivou a enxergar os hábitos e a tentar entender o que do conceito de mãe não estava claro e eu tinha vontade de clarear.

Com as entrevistadas pude perceber também hábitos que eu compartilhava com as mães e que passavam a se tornar mais conscientes à medida que as entrevistas se sucediam. Também fiquei tentando encontrar em suas falas possíveis resíduos que indicassem os hábitos maternos no próprio modo de falar a língua, e não apenas nos significados das palavras que diziam. Fiquei buscando por aquilo que significasse em termos de hábitos no modo como cada uma se expressava. Mas parei para pensar que isso só seria possível de ser identificado 
se eu as tivesse conhecido antes de tornarem-se mães. Nesse caso, eu poderia traçar diferenças entre $\mathrm{o}$ antes e o depois.

Essa foi uma questão minha, fiquei pensando se, na tentativa de transmitir certos valores para a criança, as mães não começariam a falar de forma diferente. Por exemplo, na tentativa de impor respeito, a mãe não passaria a ter um modo de falar mais firme. Ou, talvez, a tentativa de ser uma pessoa mais calma para ter paciência com o filho não levaria o modo de falar da pessoa a ser outro. Ou mesmo a tentativa de educar não levaria a mãe a tentar falar o português mais em acordo com as normas gramaticais. Enfim, fiquei pensando no quanto as transformações no self modificam a língua e o modo de expressá-la.

Fiquei durante a pesquisa fazendo o paralelo: as mulheres, ao se verem na situação de serem mães, passam por processos de inquirição que levam a formação de crenças. E eu como pesquisadora também passo por processos de inquirição para também formar uma opinião sobre o que estou estudando a partir de uma dúvida inicial. E para formar minha opinião, fui buscar as dúvidas, processos de inquirição e crenças dessas mães.

No meu trabalho investigo os processos de semiose a partir do modelo triádico de Peirce, que envolve representamen, objeto e interpretante. A semiose acontece na interação das três categorias de Peirce, a primeiridade, a secundidade e a terceiridade. $\mathrm{O}$ self então se constitui da interação dessas três categorias. Para o entendimento dos processos de semiose, trabalhei também com o conceito de semiosfera, de Lotman, que é um espaço abstrato onde estão submersos linguagens e códigos, organizados em níveis de formação de sentido. O que está no centro da semiosfera é o que autodescreve o todo. Nas margens estão estruturas mais informes. É pela fronteira que ocorrem as transformações mais evidentes, que são capazes de modificar o todo.

Então na pesquisa identifico que textos e ideias feministas são capazes de modificar o todo que seria a memória social referente à maternidade, trazendo novas concepções do que é ser mãe, para além da ideia de completude. Esses textos permitiriam também atribuir um valor diferenciado à maternidade. No decorrer da investigação percebi que a angústia das mulheres ao terem filhos, que eu buscava compreender na entrada desse tema na minha dissertação, tinha relação estreita com a ideia de que, apesar de a maternidade ter um valor fundamental na vida das mulheres, ela não é tão valorizada socialmente, ficando restrita a ordem do privado. Enfim, as ideias feministas formam perspectivas também nesse sentido, de trazer a maternidade para a esfera pública.

Quase sempre, ao falar do tema desta dissertação para as pessoas, fui questionada se eu tinha filhos. O mestrado me levou a refletir também sobre isso, sobre o modo como posso 
nomear o conceito de mãe, fugindo do hábito de vê-la como algo que vá completar a mulher, mas como algo que vem para redimensioná-la na atuação do espaço público, tornando-a protagonista da ampliação de valores feministas na relação mãe-filho-sociedade. Quando as mulheres conseguem essa maternidade defendem posições políticas e lutam por direitos a partir de suas necessidades, desafiando assim as bases ideológicas que sustentam desigualdades em que as colocam e posição de subordinação. Espero ter contribuído para este debate, que se amplia.

Se no início da abordagem do tema maternidade, eu trazia a premissa de que ela estaria associada à noção de pureza - associada à virgem Maria -, agora, após o desenvolvimento da pesquisa. Depois de conversar com as mães entrevistadas, depois de passar a perceber e me inserir em cada conversa cotidiana que tinha por tema a maternidade, após aguçar os ouvidos cada vez que essa temática surgia nas falas cotidianas. Depois, também, de me debruçar sobre as referências sociais à maternidade a partir do referencial teórico escolhido, aquela primeira noção vaga de que existiria a relação entre mãe e pureza passou a ser entendida por mim desde uma nova concepção. Primeiro porque descobri outros hábitos vigente na cultura, como a ideia da completude. Depois porque, por meio das conversas que tive e da busca pelas crenças, tive a oportunidade de constatar mais claramente, e a partir de um novo ponto de vista - como pesquisadora - as memórias comuns que eu tinha com as pessoas com quem falava. Além disso, passei a questionar os hábitos encontrados a partir das ideias feministas e também passei a me colocar de outra forma enquanto mulher e talvez, no futuro, enquanto mãe. 


\section{REFERÊNCIAS BIBLIOGRÁFICAS}

AGOSTINHO, Santo. Confissões (digitação Lúcia Maria Csernik), 2007. Disponível em: <http://img.cancaonova.com/noticias/pdf/277537_SantoAgostinho-Confissoes.pdf pg 5>

ANDACHT, Fernando. El lugar de la imaginación en la semiótica de C. S. Peirce. Anuario Filosófico, v. 19, $\mathrm{N}^{\mathrm{o}}$ 3, 2006. Consultada versão digital. Disponível em: <http://www.unav.es/gep/AF/Andacht.html> Acesso em 20 de setembro de 2016.

. Self y creatividad en el pragmatismo de C.S. Peirce: la incidencia del instante presente en la conducta. Utopía y praxis latinoamericana. v.13, $\mathrm{N}^{\mathrm{o}} 20,2008$. Disponível em: <http://www.scielo.org.ve/scielo.php?script=sci_arttext\&pid=S1315$52162008000100003 \& \operatorname{lng}=\mathrm{en} \& \mathrm{nrm}=\mathrm{i}$ so\&ignore=.html $>$ Acesso em 20 de setembro de 2015.

BADINTER, Elizabeth. Um amor conquistado: o mito do amor materno. Rio de Janeiro: Nova Fronteira S/A, 1985.

BAMBERGER, Joan: El mito del matriarcado: ¿por qué gobiernan los hombres en las sociedades primitivas? In: HARRIS, O.; YOUNG, K. (comps.): Antropología y feminismo. Anagrama, Barcelona, 1979. Disponível em: <https://seminarioatap.files.wordpress.com/2013/01/joan-bamberger-el-mitodelmatriarcado.pdf $>$ Acesso em 09 de julho de 2016.

BARRENA, Sara. Razón creativa y educación. Utopía y Praxis Latinoamericana. 2008, p. 11-38. Disponível em: <http://www.unav.es/gep/BarrenaUtopia.html> Acesso em 10 de setembro de 2016.

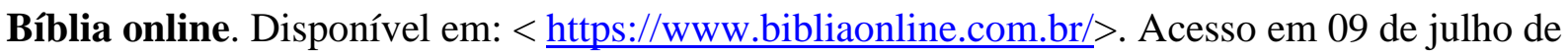
2016.

BORGES, Jorge Luis. Funes el Memorioso. In: BORGES, Jorge Luis. Ficciones. Barcelona: Peguim Random House Grupo Editorial, 2015.

BOSI, Ecléa. Memória e sociedade: lembranças de velhos. São Paulo: Companhia das letras, 2015.

BRENNAN, Teresa. Para além do falo: uma crítica a Lacan do ponto de vista da mulher. Rio de Janeiro: Editora Rosa dos tempos, 1989.

BUTLER, Judith. Corpos que pesam: sobre os limites discursivos do "sexo". In: LOURO, Guacira Lopes. O corpo educado: pedagogias da sexualidade. $2^{\mathrm{a}}$ ed., Belo Horizonte: Autêntica, 2001. Versão digital, disponível em: <https://repositorio.ufsc.br/bitstream/handle/123456789/1230/Guacira-LopesLouro-O-CorpoEducado-pdf-rev.pdf?sequence=1> Acesso em 02 de novembro de 2016.

CARBY, Hazel. Mujeres blancas, ¡escuchad! El feminismo negro y lós límites de la hermandad femenina. In: TRUTH, Sojourner; WELLS, Ida; COLLINS, Patricia H.; DAVIS, Angela; STACK, Carol; CARBY, Hazel; PARMAR, Pratibha; IFEKWUNIGWE, Jayne; ANG-LYGATE, Magdalene (orgs.). Feminismos Negros: uma antologia. Madrid: Traficantes de 2012 Sueños, Disponível em: 
$<$ https://www.traficantes.net/sites/default/files/pdfs/Feminismos\%20negrosTdS.pdf $>$ Acesso em 02 de novembro de 2016.

COLAPIETRO, Vicent M. Peirce e a abordagem do self. São Paulo: Intermeios, 2014.

CORTÁZAR, Julio. Histórias de Cronópios e de Famas. São Paulo: Círculo do Livro, [1964] 1982.

D'ORS, Eugenio. La Filosofia del Hombre que Trabaja y que Juega. Madrid: Libertarias/Prodhufi, S.A, 1995.

DUARTE, Jorge. Entrevista em profundidade. In: BARROS, Antonio; DUARTE, Jorge. Métodos e Técnicas de Pesquisa em Comunicação. São Paulo: Atlas S.A, 2005, 2.ed.

FIORIN, José Luiz. A noção de texto na semiótica. Organon, Rio Grande do Sul, v. 31, n60, p. 165-176, 1995.

GABA, Susana B. (Org.) Diccionario de estudios de género y feminismos. Buenos Aires: Editora Biblos, 2007.

GREIMAS, Algirdas Julien. Semiótica Figurativa e Semiótica plástica. In: Semiótica Plástica. São Paulo: Hacker editores, p. 75-96, 2004.

HALBWACHS, Maurice. A memória coletiva. São Paulo: Centauro, 2003.

IZQUIERDO, Iván. Memória. Porto alegre, RS: Artmed editora S.A, 2002.

JAMES, Willian. A vontade de crer. São Paulo: Edições Loyola, 2001

LACAN, Jacques. Escritos [tradução Vera Ribeiro]. Rio de Janeiro: Zahar, 1998.

LAKATO, Eva Maria; MARCONI, Marina de Andrade. Metodologia do trabalho científico. São Paulo: Editora Atlas, 2012.

LANDOWSKI, Eric. O olhar comprometido. Galáxia, São Paulo, n², p. 19-56, 2001.

LISPECTOR, Clarice. Perdoando Deus. 1970. Disponível em: < http://www.ip.usp.br/portal/index.php?option=com_content\&view=article\&id=4398: contoqperdoando-deusq-clarice-lispector-1991970\&catid=409:arquivo-ip\&Itemid=94\&lang=pt $>$. Acesso em 09 de julho de 2016.

LOTMAN, Iuri M. La semiosfera I: semiótica de la cultura y del texto. Madrid: Frónesis Cátedra Universitat de Valéncia, 1996.

MAGNE, Augusto. Dicionário Etimológico da língua latina: Família de Palavras e Derivações Vernáculas. Rio de Janeiro: Ministério da Educação e Cultura: Instituto Nacional do Livro, 1961

MARINHO, Fernanda. A Virgem amamentando o Menino e São João Batista criança em adoração. Revista de história da arte e arqueologia, Unicamp, v. 14, p. 57-89. Consultada versão digital. Disponível em: 
〈http://www.unicamp.br/chaa/rhaa/downloads/Revista\%2014\%20-\%20artigo\%204.pdf >

Acesso em 2 de novembro de 2016.

MEAD, George H. Mind, self, \& society. Chicago: The university of Chicago, 1962.

NAVARRO-SWAIN, Tania. As teorias da carne: corpos sexuados, identidades nômades. Labrys, Revista de Estudos Feministas, web, v. 1-2, n. jan/dez, 2002. Disponível em: $<$ http://www.tanianavarroswain.com.br/brasil/anahita3.htm $>$ Acesso em 02 de novembro de 2016.

PEIRCE, Charles S. A fixação da crença. Tradução de Anabela Gradim. Editora Luso Sofia: press, $1877 . \quad$ Disponível em: <http://www.lusosofia.net/textos/peirce_a_fixacao_da_crenca.pdf> Acesso em 02 de novembro de 2016.

Como tornar as nossas ideias claras. [Tradução de António

Fidalgo], Universidade da Beira Interior, 1878. Disponível em:

<http://www.bocc.ubi.pt/_listas/tematica.php?codtema=12> Acesso em julho de 2016.

Semiótica, São Paulo: Perspectiva, [1931] 2015.

The Collected Papers of Charles Sanders Peirce. Vol. I-VIII,

C. Hartshorne, P. Weiss \& A. Burks (eds.). Cambridge, MA: Harvard University Press, 1931- 1958.

RAGO, Margareth. Epistemologia feminista, gênero e história. In: PEDRO, Joana Maria e GROSSI, Miriam Pilar (orgs.). Masculino, feminino, plural. Florianópolis: Editora Mulheres, 2000. $21-42 . \quad$ p. 2 Disponível em: <http://projcnpq.mpbnet.com.br/textos/epistemologia_feminista.pdf $>$ Acesso em 02 de novembro de 2016.

RICOEUR, Paul. A memória, a história e o esquecimento. Campinas: Editorna Unicamp, 2007.

RODRIGUES, Lorena S. B. O retorno a memórias de infância pela TV e o pragmaticismo. In: FREITAS, Angélica F.; GERALDES, Elen Cristina e NERGRINI, Vanessa (Orgs). Em busca da consciência metodológica: limites e possibilidades da pesquisa em comunicação. São Paulo: Baraúna, 2016. p. 107-121.

RUSSI, Pedro. Juegos inferenciales: methodeutic y musement. La ciencia es vivencia. In: RUSSI, Pedro (Org.) Eugenio d'Ors e Charles S. Peirce: jogo e pragmatismo em ação [recurso eletrônico], Sarapuí, SP: OJM editora, 2016, p.162-197.

Meios de comunicação na migração. Uruguaios no Sul do Brasil. Porto Alegre: Entremeios, 2010.

SALLES, Cecilia Almeida. Sujeito semiótico pelo olhar de Vicent Colapietro. In: COLAPIETRO, Vicent M. (Prefácio). Peirce e a abordagem do self. São Paulo: Intermeios, 2014. 
SCOTT, Joan. Gênero: uma categoria útil de análise histórica. Educação e realidade, Porto Alegre: UFRGS, vol. 20, n. 02, 1995, p.71-99. Disponível em: <https://docs.google.com/file/d/0B1cHNDJbqFSpSWw2blFLWElSOG16MmdwU05mNEFN UQ/edit?pli=1> Acesso em 02 de novembro de 2016.

SILBERSTEIN, Emília. Iconicidade. In: RUSSI, Pedro (Org.). Processos semióticos em comunicação, Brasília: Editora Universidade de Brasília, 2013, p. 85-103.

SLOTERDIJK, Peter. Esfera I: burbujas. Microsferología. [tradução Isiodoro Reguera], 1998. Versão digital ESPA PDF.

WAAL, Cornelis. James: pragmatismo e a vontade de acreditar. In: WAAL, Cornelis. Sobre Pragmatismo. São Paulo: Edições Loyola, 2007.

WEBER, M. A objetividade do conhecimento nas ciências sociais. In: COHN, G. (Org.) Max Weber: sociologia, São Paulo: Ática, p. 79-127, 1999.

YATES, France. A arte da memória. Campinas: Editora Unicamp, 2007. 